МИНИСТЕРСТВО НАУКИ И ВЫСШЕГО ОБРАЗОВАНИЯ РОССИЙСКОЙ ФЕДЕРАЦИИ

ФГАОУ ВО «Уральский федеральный университет имени Первого президента России Б.Н. Ельцина»

ФГБОУ ВО «Уральский государственный экономический университет»

\author{
П.П. Князев, М.Н. Клименко, Д.В. Моторнюк
}

\title{
БАНКОВСКИЕ ПРОДУКТЫ И УСЛУГИ: ИНВЕСТИЦИОННОЕ КРЕДИТОВАНИЕ
}

Учебное пособие

Рекомендовано для студентов высших учебных заведений, обучающихся по направлению подготовки «Экономика» (квалификация (степень) «бакалавр») 
УДК 336.77.067.22

ББК 65.262

Б23

\author{
Aвторы: \\ П.П. Князев, М.Н. Клименко, Д.В. Моторнюк
}

Рецензенты:

Ковалева Т.М. - доктор экономических наук, профессор, заведующий кафедрой финансов и кредита, ФГБОУ ВО «Самарский государственный экономический университет», г. Самара;

Гриднев В.И. - кандидат экономических наук, генеральный директор ООО «Консалтинг Центр», г. Екатеринбург

Банковские продукты и услуги: инвестиционное кредиБ23 тование [Текст]: учеб. пособие / П.П. Князев, М.Н. Клименко, Д.В. Моторнюк. - М.: Евроазиатская научно-промышленная палата, 2019. - 148 c.

\title{
ISBN 978-5-6042079-7-0 \\ DOI 10.17513/np.358
}

В учебном пособии рассматриваются теоретические и практические аспекты разработки и реализации банковских продуктов и услуг с обоснованием сущности, целей и классификации инвестиционного кредитования. Представляются результаты прикладного анализа современного состояния инвестиционного кредитования в России.

Учебное пособие адресовано студентам высших учебных заведений, обучающихся по направлению подготовки «Экономика» (квалификация (степень) «бакалавр»), преподавателям и специалистам-практикам.

\section{ISBN 978-5-6042079-7-0}

(C) Князев П.П., Клименко М.Н., Моторнюк Д.В., 2019

(C) Евроазиатская научно-промышленная палата 


\section{ВВЕДЕНИЕ}

На современном этапе экономического развития кредит является важным элементом инвестиционных процессов, осуществляемых предприятиями реального сектора. Уровень и масштаб инвестиционной активности субъектов хозяйствования обеспечивает высокие темпы развития, повышение конкурентоспособности и эффективность их деятельности в долгосрочной перспективе.

В значительной мере с помощью кредита обеспечиваются экономические взаимоотношения в рамках перераспределения денежных средств, в целях создания на их основе новой стоимости. Определяющее значение при этом имеет инвестиционное кредитование.

Кредитная деятельность является конституирующим признаком коммерческого банка. Технологический уровень предоставления кредитных ресурсов, в том числе инвестиционных кредитов, является основополагающим показателем результативности функционирования кредитной организации и качества осуществляемого администрирования внутренних бизнес-процессов.

В настоящее время необходимо активно использовать накопленный отечественный и зарубежный опыт в сфере инвестирования. Участникам инвестиционных процессов необходимо выработать единые принципы, применять оптимальные методы и сформировать инструментарий рационального регулирования инвестиционной деятельности. Все это свидетельствует об исключительной важности построения четкого и адекватного механизма инвестиционно-кредитного процесса, как для самих коммерческих банков, так и для национальной экономики в целом.

Актуальность научно-практических исследований по инвестиционному кредитованию обуславливается возрастающей значимостью 


\section{П.П. Князев, М.Н. Клименко, Д.В. Моторнюк}

инвестиций для экономики страны и деятельности конкретных субъектов хозяйствования; для коммерческих банков, осуществляющих кредитование инвестиционных проектов; для совершенствования концептуальных подходов к финансово-кредитному регулированию инвестиционной деятельности.

Целями учебного пособия являются: изучение теоретико-методологической базы функционирования кредита и инвестиций; разработка прикладных методических основ инвестиционного кредитования; обоснование целесообразности масштабного внедрения инвестиционного кредита как фактора развития национальной экономики.

Задачи учебного пособия определяются поставленной целью в следующих направлениях:

- изучение теоретического содержания категорий «кредит» и «инвестиции» с целью научного обоснования и систематизации их теоретико-методологических позиций в экономической системе;

- определение основных признаков кредита и инвестиций с целью формирования комплексной классификации инвестиционного кредита;

- анализ основных тенденций социально-экономического развития и инвестиционной активности в национальной экономике России;

- обоснование базовых организационно-управленческих решений в ходе инвестиционно-кредитного администрирования, осуществляемого коммерческим банком;

- разработка методических решений по инвестиционному кредитованию с целью расширения практической реализации этого сегмента в деятельности коммерческих банков.

Предмет - совокупность экономических отношений, формирующихся между кредитной организацией и предприятиями реального сектора в ходе принятия инвестиционных решений и их кредитования.

Объект - деятельность коммерческих банков как финансовых институтов, организующих инвестиционное кредитование, и субъектов хозяйствования как инициаторов инвестиционных проектов.

Теоретической и методологической основой учебного пособия выступили труды российских и зарубежных ученых-экономистов по теории финансов и кредита. Значимый вклад в теорию 
исследуемых проблем внесли А.И. Архипов, Г.Н. Белоглазова, И.А. Бланк, М.З. Бор, В.В. Бочаров, О.Б. Веретенникова, А.Ю. Казак, О.И. Лаврушин, В.Е. Леонтьев, М.С. Марамыгин, Г.Б. Поляк, В.М. Родионова, М.В. Романовский, В.К. Сенчагов, А.М. Тавасиев, М.А. Федотова, Д.В. Бейли, И. Бернар, Дж.Л. Гитман, М.Д. Джонк, Дж.М. Кейнс, Ж.-К. Колли, П. Массе, Н. Ордуэй, Дж.М. Розенберг, Дж. Фридман, У.Ф. Шарп. Научно-теоретические труды ведущих ученых-экономистов раскрывают основные положения теоретических основ финансов, кредита и инвестиций; представляют экономическую природу и функциональное назначение процесса кредитования; содержат теоретико-методологическое обоснование долгосрочного кредитования; определяют роль кредитных операций в деятельности коммерческого банка.

Информационно-эмпирическая база учебного пособия включает в себя законодательные акты Российской Федерации; нормативные документы Банка России, Министерства экономического развития Российской Федерации, Министерства финансов Российской Федерации; статистические данные Федеральной службы государственной статистики; практические материалы коммерческих банков; публикации в специализированных экономических изданиях и сети Интернет.

Практическая значимость учебного пособия заключается в реализации основных рекомендаций в деятельности коммерческих банков при организации процесса инвестиционного кредитования и внедрении процедуры инвестиционно-кредитного администрирования. Разработанная авторами методика инвестиционно-кредитной экспертизы может использоваться кредитными структурами коммерческих банков при принятии организационно-управленческих решений по кредитованию инвестиционных проектов. Финансовые службы предприятий могут использовать предложенные модели для оценки возможности получения инвестиционных кредитов в целях воплощения долгосрочных программ развития бизнеса. 


\section{ГДава 1. ТЕОРЕТИЧЕСКИЕ ОСНОВЫ И ЭКОНОМИЧЕСКАЯ СУЩНОСТЬ ИНВЕСТИЦИОННОГО КРЕДИТОВАНИЯ}

\section{1. Кредит и инвестиции как категориадыные элементы экономической системы}

Динамичное развитие национального хозяйства России невозможно без дальнейшего поддержания высоких темпов инвестиционной деятельности, и прежде всего в промышленности. Определяющая роль в этом процессе в условиях российской экономики принадлежит государственному регулированию и финансовому обеспечению инвестиционной сферы.

Анализ важнейших проблем, возникающих в экономике страны, позволяет сделать вывод о том, что большинство из них концентрируются в инвестиционной сфере. Поэтому усиление инвестиционной активности в реальном секторе экономики имеет принципиальное значение для обновления производственного потенциала промышленности, строительства, транспорта, сельского хозяйства и других базовых отраслей национальной экономики.

Сложность исследования любого вопроса в области финансовокредитных отношений связана с существованием ряда дискуссионных моментов и отсутствием в отечественной науке единого мнения. В соответствие с этим определение сущности ведущих категорий является наиболее важным направлением финансовой науки.

В учебном пособии изучаются категории «кредит» и «инвестиции» в определенной смысловой последовательности. С обоснованием их взаимосвязи.

Рассмотрим категорию «кредит», формулировка которой происходит от лат. creditum - нечто, переданное другому с уверенностью в возврате; англ. credit.

При рассмотрении категории «кредит» авторы, руководствуясь методологической целесообразностью, провели группировку близких 
по содержанию определений, которые приводятся ведущими российскими учеными-экономистами.

А.М. Бабич и Л.Н. Соколова определяют кредит - как совокупность экономических отношений, возникающих между кредитором и заемщиком по поводу ссуженной стоимости, движение которой должно обеспечить эффективное размещение, использование и возврат. Важным элементом данного определения, по мнению авторов, является выделение необходимости обеспечения эффективности размещения, использования и возврата кредита. Что в свою очередь определяет необходимость проведения анализа при выборе, как заемщика, так и кредитора.

Коллектив ученых-экономистов: Л.И. Сергеев, А.Н. Соколов, В.П. Жданов, А.Г. Мнацаканян представляют кредит в качестве экономических отношений по поводу движения ссудного капитала и особой формы перемещения денег, включающих в себя мобилизацию свободных денежных средств народного хозяйства и населения и их перераспределение на условиях возвратности, срочности, платности в целях расширенного воспроизводства. Исходя из этого определения, кредит как экономическая категория выражает определенные отношения общества, являющиеся составной частью производственных отношений. Данные отношения возникают между кредитором и заемщиком по поводу предоставления и возвратного движения ссуды.

Аналогичное определение дают В.Е. Леонтьев и Н.П. Радковская считая, что кредит - это движение ссудного капитала, включающее в себя мобилизацию свободных денежных средств народного хозяйства и населения, и их перераспределение на условиях возвратности, срочности, платности в целях расширенного воспроизводства.

Коллектив ученых-экономистов: А.Ю. Казак, О.Б. Веретенникова, М.С. Марамыгин, К.В. Ростовцев определяют кредит - как форму движения ссудного капитала (ссуженной стоимости), обеспечивающую трансформацию денежного капитала в ссудный и отражающую отношения между кредитором и заемщиком. Иными словами кредит обеспечивает видоизменение денежного капитала в ссудный путем выделения субъектов данных отношений и условий, определяющих срочность, платность и возвратность. 


\section{П.П. Князев, М.Н. Клименко, Д.В. Моторнюк}

Близкое по значению, но более сжатое определение кредита дают В.К. Сенчагов, А.И. Архипов: «Кредит представляет собой форму движения ссудного капитала, т. е. денежного капитала, предоставляемого в ссуду».

О.И. Лаврушин характеризует кредит - как передачу кредитором ссуженной стоимости заемщику для использования на началах возвратности и в интересах общественных потребностей. В данном определении проводится выделение общественного значения кредита. По мнению авторов, кредит действительно играет важную роль в удовлетворении общественных потребностей путем реализации своих функций, особенно перераспределительной.

Коллектив ученых-экономистов: М.В. Романовский, О.В. Врублевская, Б.М. Сабанти под кредитом понимают предоставление денег или имущества другому юридическому или физическому лицу в собственность на условиях срочности, возвратности и платности. В определении подчеркивается не только денежная форма кредита, но и возможность предоставления ссудного капитала в имущественной форме. С законодательного обоснования в определении приведена важная юридическая составляющая кредитных отношений - ресурсы, передаваемые кредитором в ссуду заемщику, переходят к последнему в собственность. Вместе с тем, по мнению авторов, несогласованным моментом является трактовка кредита как отношений между юридическими и физическими лицами, так как участниками кредитной сделки могут быть государство или его субъекты.

Идентичное определение дает Г.Б. Поляк, который считает, что кредит - ссуда в денежной или товарной форме на условиях возвратности, платности и срочности.

Современный финансово-кредитный словарь определяет кредит - как ссуду в денежной или товарной форме, предоставляемую кредитором заемщику на условиях возвратности, платности и других на основе заключения между кредитором и заемщиком кредитного договора. В определении происходит выделение возможности выполнения кредитной сделки на дополнительных условиях (целевой характер и т.д.), а также учитывается юридический аспект, который обозначает оформление данной сделки только в документарной форме. 
О.М. Островская определяет кредит - в качестве займа, предоставляемого в денежной форме на условиях возвратности и, как правило, платности (в виде процентов за пользование кредитом). В рассматриваемом определении затрагивается юридический аспект, при этом неверно охарактеризована возможность существования условия «платности». Данное условие в обязательном порядке зафиксировано законодательным полем, действующим в государстве. Кредитная сделка не может быть бесплатной для заемщика, даже если в качестве исключения устанавливается нулевой процент.

Финансово-кредитный энциклопедический словарь определяет кредит - как экономическую сделку, при которой один партнер предоставляет другому денежные средства или имущество на условиях срочности, возвратности и платности. Важным является выделение экономической составляющей кредитной сделки с участием партнеров как субъектов отношений. Однако, партнерство как процесс ведения экономических операций не всегда присутствует во взаимоотношениях кредиторов и заемщиков.

По итогам изучения различных взглядов на категорию «кредит» авторы дополняют и конкретизируют определение данной категории.

Кредит - это экономические отношения в форме движения ссудного капитала, которые возникают между кредитором и заемщиком на основе заключения кредитного договора, определяющего предоставление в собственность денежных средств или имущества на условиях платности, срочности и возвратности, и реализуются в интересах удовлетворения общественных потребностей.

Кредит представляет собой форму движения ссудного капитала, т. е. совокупности денежных капиталов, отданных в ссуду. Источники формирования ссудного капитала представлены на рис. 1.

Кредит обеспечивает трансформацию денежного капитала в ссудный и выражает отношения между кредиторами и заемщиками. При его помощи свободные денежные капиталы и доходы физических, юридических лиц, государства в рамках экономической системы аккумулируются, превращаясь в ссудный капитал, передаваемый за плату во временное пользование. 


\begin{tabular}{|c|c|c|}
\hline \multicolumn{3}{|c|}{ Источники с судного капитала } \\
\hline $\begin{array}{c}\text { Внеоборотная часть } \\
\text { промышленного и торгового } \\
\text { капитала }\end{array}$ & $\begin{array}{c}\text { Свободные денежные средства } \\
\text { населения и хозяйствующих } \\
\text { субъектов }\end{array}$ & $\begin{array}{c}\text { Денежные накопления } \\
\text { государства }\end{array}$ \\
\hline $\begin{array}{l}\text { 1. Денежные средства, накапливаемые } \\
\text { в амортизационном фонде } \\
\text { 2. Часть оборотного капитала в } \\
\text { денежной форме, об разующаяся в } \\
\text { результате несовпадения поступления } \\
\text { выручки и осуществления з атрат } \\
\text { 3. Часть прибыли, накапливаемая до } \\
\text { определенного объема и направляемая } \\
\text { для обновления и расширения } \\
\text { производства } \\
\text { 4. Часть нераспределенной прибыли, } \\
\text { до ее фактическогораспределения и } \\
\text { использования }\end{array}$ & $\begin{array}{l}\text { 1. Денежные средства, } \\
\text { накапливаемые на депозитных } \\
\text { или сберегательных счетах } \\
\text { 2. Денежные средства на } \\
\text { расчетных счетах } \\
\text { 3. Денежные средства, } \\
\text { переданные в доверительное } \\
\text { управление } \\
\text { 4. Денежные средства, } \\
\text { вложенные в ценные бумаги, } \\
\text { эмитентом по которым } \\
\text { выступает кредитор }\end{array}$ & $\begin{array}{l}\text { 1. Денежные средства, } \\
\text { получаемые в качестве доходов } \\
\text { от сдачи в аренду } \\
\text { государственной } \\
\text { собственности } \\
\text { 2. Денежные средства, } \\
\text { полученные от продажи } \\
\text { государственной } \\
\text { собственности } \\
\text { 3. Денежные средства, } \\
\text { полученные государством в } \\
\text { управление }\end{array}$ \\
\hline
\end{tabular}

Рис. 1. Источники формирования ссудного капитала

\section{Сущность любой экономической категории проявляется}

в выполняемых ею функциях и принципах осуществления. Кредит не является исключением и имеет свою собственную основу применения, находящую отражение в конкретных функциях и принципах, на которых строится кредитный процесс и управление денежным оборотом общества.

Выделение функций кредита является дискуссионным вопросом в отечественной экономической науке. Ряд ученых-экономистов выделяют следующие функции: функция аккумуляции временно свободных денежных средств, перераспределительная функция, функция замещения наличных денег и сокращения издержек обращения. Дадим более подробную характеристику внутреннего содержания функций кредита.

Функция аккумуляции временно свободных денежных средств как отдельно существующая выделяется ограниченным кругом ученых-экономистов. В рамках данной функции осуществляется аккумуляция временно свободных денежных средств, что является основой для расширенного воспроизводства в экономике. Приток 
денежных средств хозяйствующему субъекту не означает необходимости немедленного их использования. Кроме возмещения затрат, прибыль по прошествии определенного времени распределяется на нужды потребления и накопления. В результате формируются денежные средства, накапливаемые в настоящее время для потребления их в будущем периоде. Эти средства временно высвобождаются из процесса кругооборота хозяйствующего субъекта и используются в качестве заемных средств.

Перераспределительная функция рассматривается и признается большинством ученых-экономистов. Ее содержание состоит в том, что посредством кредита происходит аккумулирование свободных денежных ресурсов юридических и физических лиц, превращение их в ссудный капитал и при помощи кредитного механизма передача во временное распоряжение на платной основе различным субъектам хозяйствования и населению. Таким образом, происходит перераспределение ссудного капитала между предприятиями, отраслями, населением, а также концентрация его в тех сферах, которым отдается предпочтение, т.е. капитал в денежной форме высвобождается из сфер с низкой нормой прибыли, накапливается в кредитных учреждениях и далее направляется в те отрасли, где будет использован с наибольшей эффективностью.

Функция замещения наличных денег и сокращения издержек обращения аналогично перераспределительной выделяется широким кругом ученых-экономистов. Действительно, в процессе кредитования создаются различные платежные средства для обслуживания налично-денежной и безналичной форм сферы обращения, оказывающие влияние на структуру денежной массы, платежного оборота и скорости обращения денег. Происходит замещение действительных денег кредитными деньгами. Данная функция находится в зависимости от уровня развития товарно-денежных отношений, от самой денежно-кредитной системы и тех форм денег, которые существуют в обращении. Кредит способствует сокращению денежной массы в обращении, через систему взаимных зачетов долговых требований и обязательств, замещению полноценных денег кредитными, увеличению скорости оборота денег, в результате чего снижаются издержки обращения, а вместе с ними и непроизводительные расходы. 


\section{П.П. Князев, М.Н. Клименко, Д.В. Моторнюк}

Ряд ученых-экономистов, например, Л.И. Сергеев, А.Н. Соколов, В.П. Жданов, А.Г. Мнацаканян, придают категории «кредит» функцию ускорения концентрации и централизации капитала и контрольную функцию.

Функция ускорения концентрации и централизации капитала заключается в том, что кредитный механизм способствует процессу превращения прибавочной стоимости в капитал и раздвигает границы индивидуального накопления. При увеличении масштабов производства возникает ситуация, когда средства отдельных хозяйствующих субъектов являются недостаточными, поэтому отдельные части их прибавочной стоимости консолидируются и накапливаются в кредитных учреждениях и, достигнув значительных размеров, содействуют процессу расширенного воспроизводства. Кроме того, концентрации подвергаются свободные денежные средства населения. Важную роль играет кредит и в централизации капитала, так как способствует превращению индивидуальных предприятий в предприятия коллективной формы собственности. Кредитные учреждения предоставляют кредитные ресурсы предприятиям с устойчивым финансовым положением. Тем самым в результате конкурентной борьбы предприятия, испытывающие определенные финансовые трудности, могут стать объектом экономического поглощения, т.е. осуществляется централизация капитала. По мнению авторов, выделение данной функции объективно относится только к кредитным сделкам, итогом которых будет расширение деятельности заемщика.

Содержание контрольной функции сводится к контролированию финансового состояния заемщика, с целью предотвращения несвоевременного выполнения взятых на себя обязательств. Поэтому на протяжении всего кредитного процесса осуществляется контроль за соблюдением всех принципов кредитования, позволяющий кредитору принимать решения о выдаче ссуд, об ужесточении режима кредитования, либо о досрочном возврате ссуды. По мнению авторов, выделение данной функции является нецелесообразным. Объективность контрольной функции проявляется только в отдельных случаях, когда в кредитной сделке зафиксировано право кредитора 
потребовать выполнения условий сделки, данное ему в соответствие с законодательным полем. В большинстве случаев на практике кредиторы осуществляют не контроль, а мониторинг текущего состояния заемщика, и не имеют реальной возможности влиять на деятельность последнего.

По итогам анализа различных подходов к изучению функций категории «кредит», определим в качестве базовых следующие функции: аккумуляции временно свободных денежных средств, перераспределительную, замещения наличных денег и сокращения издержек обращения.

Перейдем к рассмотрению элементной составляющей кредитных отношений, т.е. исходных принципов кредитования. Кредитные отношения строятся и осуществляются при соблюдении принципов кредитования, которые представляют собой основу, т.е. главный элемент системы кредитования. Содержание принципов отражает сущность кредита как экономической категории, выражает основные взаимоотношения между кредитором и заемщиком, а также определяет выполнение требований основных экономических законов в области кредитных отношений.

Выделение и придание категории «кредит» определенного набора принципов также является вопросом дискуссионным. По мнению авторов, целесообразно осветить основные принципы, присутствующие в экономической науке, и в качестве итога выделить наиболее значимые из них. Ученые-экономисты выделяют следующие основные принципы: возвратность, срочность, платность, обеспеченность, целевой характер использования, дифференцированный подход при кредитовании. Раскроем содержание каждого принципа с авторским обоснованием.

Принцип возвратности кредита означает, что ранее взятые в долг субъектом хозяйствования кредитные ресурсы после завершения их использования должны быть возвращены. Кредит характеризуется двусторонним движением денежных средств: первоначально они направляются от кредитора к заемщику, а затем от заемщика к кредитору. Поэтому через принцип возвратности реализуется сущность кредита, как стоимости, отданной в ссуду, т. е. взаймы. 


\section{П.П. Князев, М.Н. Клименко, Д.В. Моторнюк}

В отличие от вышерассмотренного принципа, который предполагает возврат ранее взятой ссуды в целом, принцип срочности кредита означает, что ссуда должна быть возвращена в точно установленные сроки и в том порядке, которые зафиксированы в документе, отражающем процесс передачи денежных средств кредитором заемщику. Несоблюдение заранее установленных сроков возвратности ссуд дает основание применять к заемщику штрафные санкции в виде повышенных процентов, а при дальнейшей отсрочке предъявить иск на предмет залога в судебном порядке.

Ряд ученых-экономистов выделяют в качестве объективного один из приведенных принципов. Действительно в содержании рассмотренных принципов существует идентичная основа, которая определяет обязательность возврата кредитных ресурсов. Однако, по мнению авторов, наиболее объективным принципом является принцип срочности. Подобная позиция объясняется тем, что принцип срочности фиксируется документально в качестве обязательных условий кредитной сделки. Также с юридической точки зрения именно нарушение данного принципа является основанием для судебного процесса.

Принцип платности кредита означает необходимость взимания кредитором с заемщика определенной платы за временно переданные им в пользование кредитные ресурсы. Экономическая сущность данного принципа заключается в том, что заемщик оплачивает кредитору часть добавленной потребительной стоимости в денежной форме, т.е. происходит перераспределение дополнительно полученной прибыли между кредитором и заемщиком за счет использования кредитных ресурсов. Реализация рассматриваемого принципа на практике происходит через механизм установления ссудного процента. Количественное выражение цены кредитных ресурсов определяется ставкой процента, величина которого отражает соотношение спроса и предложения на рынке ссудных капиталов. Объективность принципа платности зафиксирована законодательным полем в отношении кредитных сделок с участием кредитных организаций.

Принцип обеспеченности кредита означает, что своевременный возврат ссуды заемщиком дополнительно должен быть гарантирован наличием у него конкретных видов материальных ценностей, 
поручительством третьих лиц, денежными документами или иными обязательствами в других формах, принятых практикой. В качестве первичного обеспечения ссуды, т.е. основы для возврата кредитных ресурсов, выступает денежный поток заемщика, который завершается приростом стоимости. Также активно используется вторичное обеспечение, которое представляет собой вещный капитал. Соблюдение данного принципа способствует уменьшению рисков получения убытков кредитором, так как при возможном нарушении заемщиком взятых на себя обязательств иск может быть обращен на имущество, находящееся в залоге, финансовые гарантии и поручительства третьих лиц. Однако следует заметить, что данный принцип выполняется не всегда, так как в отдельных случаях кредиты могут предоставляться без обеспечения (бланковые кредиты).

Принцип целевого характера использования означает, что предоставление кредитных ресурсов заемщику осуществляется на цели финансирования заранее известных кредитору расходов. Целевой характер использования ссуды фиксируется в соответствующем разделе кредитного договора и является объектом контроля со стороны кредитора. Данный принцип позволяет кредитору убедиться в реальности проводимой заемщиком деятельности и своевременности возврата ссуженных средств. Принцип целевого характера кредита имеет важное значение, хотя необходимо отметить, что в отдельных случаях данный принцип не выполняется.

Принцип дифференцированного подхода при кредитовании означает различные условия предоставления кредитных ресурсов потенциальным заемщикам, т. е. кредиты должны предоставляться тем субъектам хозяйствования, финансовое положение которых способствует их своевременному возврату. Кроме того, условия выдачи кредитов могут исходить из частных интересов отдельных кредиторов и единой централизованной политики, проводимой государством по отношению к различным отраслям и сферам деятельности. Данный принцип является важным с позиции современного состояния рынка ссудных капиталов, когда в зависимости от дифференцирования заемщиков на группы, кредиторами устанавливаются различные условия предоставления кредитных ресурсов. 


\section{П.П. Князев, М.Н. Клименко, Д.В. Моторнюк}

По итогам анализа подходов к определению основных принципов, присущих категории «кредит», по мнению авторов, можно выделить следующие объективные принципы, которые не зависят от переменных факторов: срочность, платность, обеспеченность, целевой характер использования, дифференцированный подход при кредитовании.

Следующим этапом научного пособия является изучение подходов к определению категории «инвестиции». Первоначально следует отметить, что нет единства в понимании сущности инвестиций как экономической категории среди ученых и экономистов.

В современной экономической литературе зарубежных и российских авторов, а также в законодательных актах встречаются различные трактовки определения инвестиций, которые зачастую не дают полной характеристики, а отражают одну из сторон этого сложного, многогранного понятия.

Термин «инвестиции» активно используется в российском экономическом лексиконе. Это предполагает рассмотрение содержания данной категории на основе анализа господствующих точек зрения.

Термин «инвестиции» происходит от латинского слова «invest», что означает вкладывать. В более широкой трактовке он выражает вложения капитала с целью его дальнейшего возрастания.

И. Бернар и Ж.-К. Колли в «Толковом экономическом и финансовом словаре» предлагают различать категории «инвестиции» (капитальные вложения), с одной стороны, и «вложение капитала», с другой стороны. Данные ученые определяют различие между указанными категориями следующим образом: ВВложение капитала отличается от инвестиции тем, что как по мотивации, так и по природе осуществляющего его субъекта, оно отделено от процесса производства. Возможная прибыль или риск, которому он при этом подвергается, зависит от прозорливости вкладчика, а не от его производительных способностей».

По мнению авторов, в данном определении вложение капитала трактуется как операция в сферу, не связанную с профессиональной деятельностью или компетенцией его владельца, рассчитывающего извлечь прибыль из такого размещения средств. Определение 
различий между категориями «инвестиции» и «вложение капитала» дает возможность выделить один из важнейших признаков «инвестиций» как экономической категории - производительный характер использования капитала, в то время как термин «вложение капитала» применяется к характеристике финансовых операций: деньги, депозиты, ценные бумаги и т.д.

Одновременно с выделением данного признака действует методологический аспект, который выражается в том, что производительность, а также долгосрочный характер расходования средств часто позволяет поставить знак равенства между инвестициями и капитальными вложениями, что в определенной степени является не корректным.

Следует отметить, что европейская методология допускает распространение термина «инвестиции» и на долгосрочные вложения в ценные бумаги, но в строгом смысле слова это допустимо лишь в приобретении участия, отражающего возможность управлять корпорацией. Следовательно, в этом случае такое вложение капитала есть инвестиции. По мнению авторов, в данном контексте речь идет о приобретении пакета ценных бумаг, структурный объем которого представляет владельцу реальную возможность фактического влияния на деятельность компании-эмитента. Американская методология также ставит знак равенства между категориями «инвестиции» и «капитальные вложения», выделяя в их экономическом содержании направленность вложений в недвижимость.

Экономическая наука и практика подтверждают, что капитальные вложения не являются синонимом инвестиций и данные термины не тождественны. Инвестиции являются более широким понятием, чем капитальные вложения. Инвестиции в основной капитал осуществляют в форме капитальных вложений; они включают в себя затраты на новое строительство, расширение, реконструкцию и техническое перевооружение действующих предприятий, приобретение оборудования, инструмента и инвентаря, проектной продукции и другие расходы капитального характера. В западной экономической литературе главное внимание уделяют рассмотрению фондового рынка, так как в странах с развитой рыночной экономикой инвестирование осуществляют с помощью ценных бумаг. 


\section{П.П. Князев, М.Н. Клименко, Д.В. Моторнюк}

Французский экономист П. Массе отмечает, что «наиболее общее определение, которое можно дать акту вложения капитала, сводится к следующему: инвестирование представляет собой акт обмена удовлетворения в будущем с помощью инвестированных благ». В данном определении инвестиции представляются как обмен сегодняшних потребностей на удовлетворение их в будущем в большом количестве. По мнению авторов, данное положение является достоверным, так как прирост капитала, полученный в результате инвестирования, должен быть достаточным, чтобы возместить инвестору отказ от потребления имеющихся средств в текущем периоде, вознаградить его за риск и компенсировать возможные потери в будущем периоде.

Ученый-экономист и основатель экономической школы Дж.М. Кейнс при определении сущности «инвестиций» выделяет двойственную оценку:

- инвестиции отражают величину аккумулированного дохода на цели накопления, то есть определяют потенциальный инвестиционный спрос;

- инвестиции являются затратами, определяющими прирост стоимости капитального имущества в результате реализации инвестиционного предложения.

В первом аспекте «инвестиции» представляют собой объем возможного получения дохода, что в свою очередь определяет экономическую целесообразность и привлекательность превращения собственных средств в инвестиционные. Второй аспект определяет «инвестиции» как совокупность затрат, необходимых для реализации инвестиционных решений. По мнению авторов, второй подход к определению «инвестиций» является более точным в связи с тем, что прогнозируемый объем дохода - это средства предполагаемые к появлению в будущем периоде при положительной экономической ситуации, получение которых не является абсолютно гарантированным.

Ученые-экономисты Дж. Фридман и Н. Ордуэй определяют «инвестиции» следующим образом: «Инвестиции (investments) - вложение денежных средств для извлечения доходов или прибыли; собственность, приобретенная для извлечения доходов или прибыли». В данной позиции подчеркивается значение «инвестиций» 
в качестве экономического процесса и непосредственно совокупности затрат, выражаемое имущественным подходом. По мнению авторов, подобная двойственная трактовка имеет комплексный характер.

С точки зрения определения инвестиций как «покупки акций или облигаций с расчетом на некоторый финансовый результат», данное Л.Дж. Гитманом, представляется недостаточно верным, так как результат может быть различным, а целью инвестиций должно быть получение прибыли либо рост капитала.

Словарь Макмиллана определяет инвестиции как «поток расходов, предназначенных для производства благ, а не для непосредственного потребления». В приведенном выше определении «инвестиции» определяются как объем затрат, вложение которого принесет экономическую выгоду (благо) в будущем периоде. Авторская позиция частично является аналогичной.

В Оксфордском толковом словаре даны следующие трактовки инвестиций: «Инвестиции (investments):

Приобретение средств производства, таких как машины и оборудование, для предприятия с тем, чтобы производить товары для будущего потребления. Обычно такое приобретение называется капитальными вложениями, вложения в средства производства (capital investments); чем выше уровень капитальных вложений в хозяйство, тем быстрее оно будет развиваться.

Приобретение активов, например, ценных бумаг, произведений искусства, депозитов в банках или строительных обществах и т.п., прежде всего в целях получения финансовой отдачи в виде прибыли или увеличения капитала. Такой вид финансовых инвестиций (financial investments) представляет собой средство сбережения. Уровень финансовых инвестиций в хозяйство зависит от таких факторов, как процентная ставка, степень возможной прибыльности инвестиций, общая стабильность делового климата». В данном определении объединены две составные части понятия «инвестиции»: «капитальные вложения» и «финансовые вложения».

У. Шарп определяет «реальные инвестиции, которые включают инвестиции в какой-либо тип материально осязаемых активов, таких как земля, оборудование, заводы. Финансовые инвестиции 


\section{П.П. Князев, М.Н. Клименко, Д.В. Моторнюк}

представляют собой контракты, записанные на бумаге, такие как обыкновенные акции и облигации». В данном определении инвестиции разделяются по объектам вложения средств. В примитивных экономиках основная часть инвестиций относится к реальным, в то время как в современной экономике большая часть инвестиций представлена финансовыми инвестициями. По мнению авторов, подобное разделение инвестиций на реальные и финансовые является целесообразным. Однако следует принимать во внимание то, что высокое развитие институтов финансового инвестирования в значительной степени способствует росту реальных инвестиций и, как правило, эти две формы являются взаимодополняющими, а не конкурирующими.

Последние определения вводят важное разграничение между капиталообразующими (реальными) инвестициями и финансовыми инвестициями. Если первые, в конечном счете, приводят к вводу в эксплуатацию новых средств производства, то вторые сводятся лишь к смене прав на собственность уже существующего имущества.

Наряду с зарубежными специалистами терминологической проблемой определения категории «инвестиции» занимаются российские ученые-экономисты. Вместе с тем, термин «инвестиции» в процессе эволюции отечественной методологии в области инвестиций не получил однозначного определения.

В административно-хозяйственной экономике СССР в рамках функционирования централизованной плановой системы использовалось понятие «капитальные вложения», под которым понимались все вложения денежных средств в воспроизводство основных средств - как производственного, так и непроизводственного характера, включая затраты на их капитальный ремонт. По мнению авторов, данное определение является не корректным потому, что отождествление понятий «инвестиции» и «капитальные вложения», как отмечалось выше, нерационально.

И.А. Бланк придерживается следующей позиции: «Инвестиции представляют собой вложение капитала во всех его формах с целью обеспечения его роста в предстоящем периоде, получения текущего дохода или решения определенных социальных задач». В данном определении выделяются в качестве задач «инвестиций»- формирование 
дохода в текущем периоде и содержание социального аспекта. По мнению авторов, социальный аспект при осуществлении инвестиций является важным для государства и общества, однако не является доминирующим с экономической точки зрения.

В.В. Бочаров рассматривает «инвестиции как выражение всех видов имущественных и интеллектуальных ценностей, которые направляются в объекты предпринимательской деятельности, в результате которой формируется прибыль (доход) или достигается иной полезный эффект». По мнению авторов, данное определение является в достаточной степени емким. В приведенной трактовке разделяются виды инвестиционных ресурсов на имущественные и интеллектуальные, делается акцент на вложение данных ресурсов в объекты предпринимательской деятельности, фиксируется возможность получения положительного эффекта иного, чем прибыль (доход).

С точки зрения М.З. Бора и А.Д. Денисова, под инвестициями в широком смысле необходимо понимать денежные средства, банковские вклады, паи, акции и другие ценные бумаги, технологии, машины, оборудование, лицензии, в том числе и на товарные знаки, кредиты, любое другое имущество или имущественные права, интеллектуальные ценности, вкладываемые в объекты предпринимательской деятельности и другие виды деятельности с целью получения доходов (прибыли), увеличения рыночной стоимости компании или достижения положительного социального эффекта. По мнению авторов, в данном определении важным аспектом является выделение кредитов - как источника инвестиций, и увеличение стоимости бизнеса компании - как результат инвестиций, который представляет вариант инвестирования средств в целях дальнейшей продажи компании или противодействия поглощению со стороны конкурентов.

В терминологическом словаре Дж.И. Розенберга инвестиции характеризуются как «использование денег для получения больших денег, для извлечения доходов или достижения прироста капитала либо для того и другого». С такой трактовкой этого понятия нельзя согласиться, так как «инвестиции» могут осуществляться не только в денежной, но и в других формах - движимого или недвижимого имущества, различных финансовых инструментов, нематериальных активов и др. 


\section{П.П. Князев, М.Н. Клименко, Д.В. Моторнюк}

М.С. Марамыгин акцентирует внимание на сущностной характеристике категории «инвестиции» - как определяемого значительным временным интервалом вложения стоимости посредством специальных инструментов с целью расширенного потребления в будущем. В данном определении исключена из термина составляющая, которая представляет «инвестиции» в виде совокупности затрат, т.е. отрицательного денежного потока.

О.Б. Веретенникова отмечает, что «инвестиции - это капитальные вложения (реальные инвестиции), направляемые для обеспечения предприятия факторами производства, а также вложения в приобретение ценных бумаг (портфельные инвестиции), окупающиеся за период более операционного цикла и требующие обязательного экономического обоснования из-за неопределенности риска. Следует согласиться с представленной трактовкой в рамках обязательности экономического обоснования и присутствия риска.

В рамках функционирования законодательного поля в Российской Федерации существуют правовые трактовки термина «инвестиции».

Федеральный закон «Об инвестиционной деятельности в Российской Федерации» дает следующее определение: «Инвестициями являются денежные средства, целевые банковские вклады, паи, акции и другие ценные бумаги, технологии, машины, оборудование, лицензии, в том числе и на товарные знаки, кредиты, любое другое имущество или имущественные права, интеллектуальные ценности, вкладываемые в объекты предпринимательской и других видов деятельности в целях получения прибыли (дохода) и достижения положительного социального эффекта».

Федеральный закон «Об инвестиционной деятельности в РФ, осуществляемой в форме капитальных вложений», дает сходное с предыдущим определение инвестиций: «Инвестиции - денежные средства, ценные бумаги, иное имущество, в том числе имущественные права, иные права, имеющие денежную оценку, вкладываемые в объекты предпринимательской и (или) иной деятельности в целях получения прибыли и (или) достижения иного полезного эффекта».

Из приведенных определений видно, что в основном источником прироста капитала и движущим мотивом осуществления инвестиций является прибыль. Инвестиции осуществляются с целью получения дохода 
(результата) и становятся бесполезными, если они его не приносят. Однако здесь же присутствует и вторая, не менее важная сторона инвестиций, а именно - вложение ресурсов для получения требуемого результата. По мнению авторов, законодательная трактовка на современном этапе является в достаточной степени емкой, хотя действующие процессы в экономике требуют определенных уточнений законодательных положений.

Следовательно, экономическое содержание инвестиций в условиях рыночной экономики заключается в сочетании двух сторон инвестиционной деятельности: затрат ресурса и получение результата. Необходимо отметить, что эти два процесса могут происходить в различной временной последовательности. Различают последовательное, параллельное и интервальное протекание процессов вложения ресурса и получения результата.

При последовательном протекании этих процессов прибыль получается сразу же после завершения инвестиций в полном объеме. При параллельном их протекании получение прибыли возможно еще до полного завершения процесса инвестирования. При интервальном протекании этих процессов между завершением инвестиций и получением прибыли проходит определенное время (продолжительность этого временного лага зависит от форм инвестирования и особенностей конкретных инвестиционных проектов).

А.Ю. Казак и Л.И. Юзвович выделяют экономическое и финансовое определение инвестиций. К примеру, согласно экономическому определению, инвестиции - «это совокупность затрат, реализуемых в форме долгосрочных вложений капитала в промышленность, сельское хозяйство, транспорт и другие отрасли экономики производственной и непроизводственной сферы».

Коллектив ученых-экономистов: А.Ю. Казак, М.С. Марамыгин, Е.Н. Прокофьева， Е.Г. Шатковская， О.А. Солодова， Т.Д. Сиколенко определяет инвестиции как вложения, которые направлены на наращивание новых основных фондов и на пополнение запасов товарно-материальных ценностей, используемых в процессе производства. В данном определении делается акцент на использование инвестиций в качестве инструмента расширения деятельности хозяйствующего субъекта.

В широком смысле инвестиции обеспечивают механизм, необходимый для финансирования роста и развития экономики страны. 


\section{П.П. Князев, М.Н. Клименко, Д.В. Моторнюк}

Часть инвестиций имеет целью стабилизировать общеэкономический процесс, экологическую обстановку, социальную сферу, либо создать принципиально новые направления техники и технологии, экономическая эффективность которых заранее неизвестна.

С финансовой точки зрения, то есть с точки зрения прибыльности денежного хозяйства предприятий всех форм собственности, инвестиции - это все виды ресурсов, вкладываемые в хозяйственную деятельность, с целью получения дохода или выгоды. Данное определение соответствует главной цели любого бизнеса - получение прибыли.

Многообразие понятий термина «инвестиции» в современной отечественной и зарубежной литературе в значительной степени определяется широтой сущностных сторон этой сложной экономической категории. Поэтому для уточнения содержания этой категории следует рассмотреть основные характеристики, формирующие ее сущность (рис. 2).

Инвестиции как объект рыночных отношений. Используемые предприятием в процессе инвестиций разнообразные инвестиционные ресурсы, товары и инструменты как объект купли-продажи формируют особый вид рынка - «инвестиционный рынок», - который характеризуется спросом, предложением и ценой, а также совокупностью определенных субъектов рыночных отношений.

Инвестиционный рынок формируется всей системой рыночных экономических условий, тесно сопряжен с другими рынками (рынком труда, рынком потребительских товаров, рынком услуг и т.п.) и функционирует под определенным воздействием разнообразных форм государственного регулирования.

Инвестиции как объект рыночных отношений. Используемые предприятием в процессе инвестиций разнообразные инвестиционные ресурсы, товары и инструменты как объект купли-продажи формируют особый вид рынка - «инвестиционный рынок», - который характеризуется спросом, предложением и ценой, а также совокупностью определенных субъектов рыночных отношений. Инвестиционный рынок формируется всей системой рыночных экономических условий, тесно сопряжен с другими рынками (рынком труда, рынком потребительских товаров, рынком услуг и т.п.) и функционирует под определенным воздействием разнообразных форм государственного регулирования. 


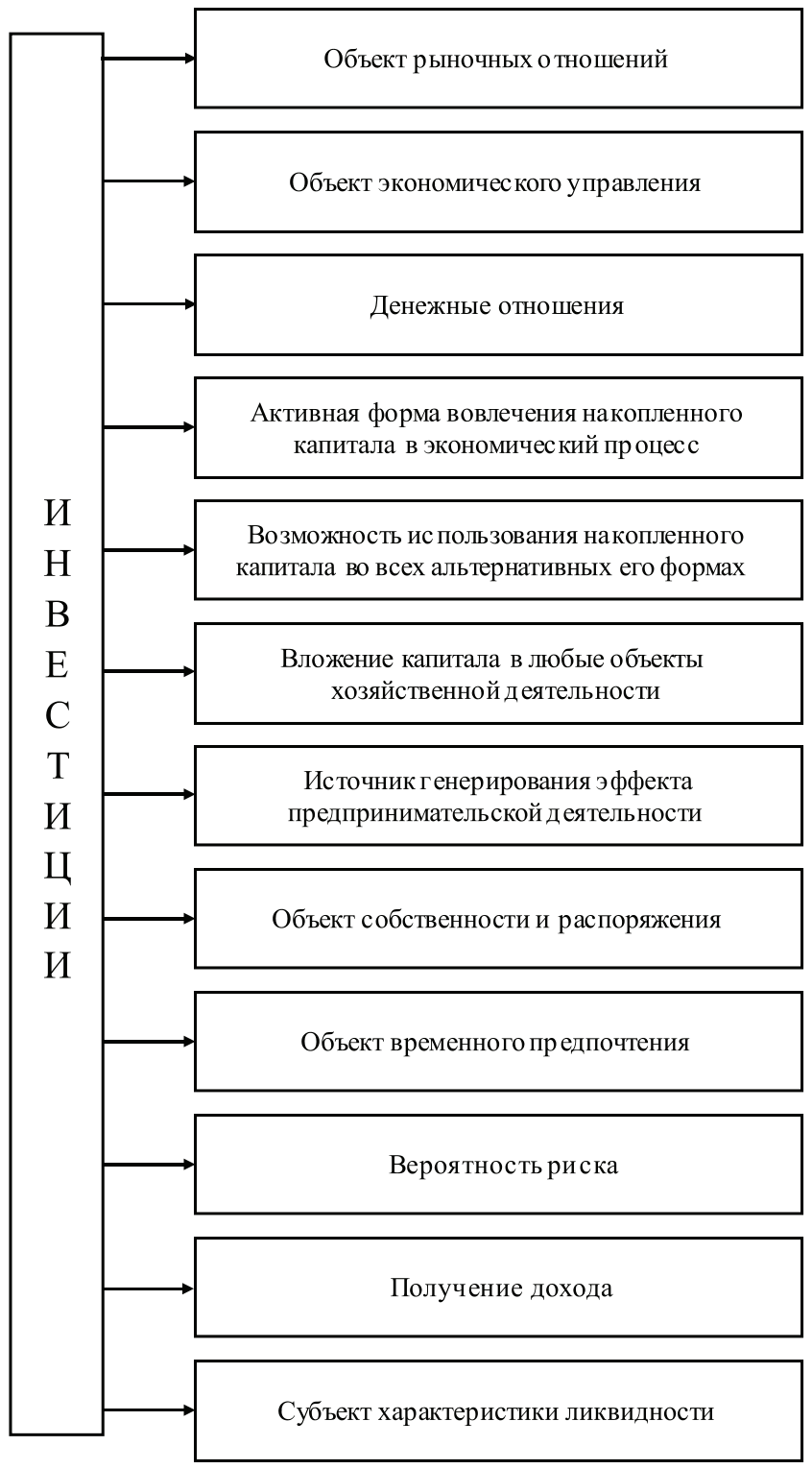

Рис. 2. Основные сущностные характеристики категории «инвестиции» 


\section{П.П. Князев, М.Н. Клименко, Д.В. Моторнюк}

Рассмотрим инвестиции как объект экономического управления. Предметная сущность инвестиций непосредственно связана с экономической сферой ее проявления. Несмотря на рассмотренные ранее достаточно значимые терминологические различия, инвестиции трактуются всеми исследователями как категория экономическая, хотя и связанная с технологическими, социальными, природоохранными и иными аспектами их осуществления.

Соответственно, выступая носителем преимущественно экономических характеристик и экономических интересов, инвестиции являются субъектом экономического управления как на микро-, так и на макроуровне любых экономических систем.

Авторы представляют инвестиции как денежные отношения по поводу формирования и использования инвестиционных ресурсов, имеющих денежную стоимость, с целью получения результата в виде возврата израсходованной стоимости и сформированного объема прибыли.

Представим инвестиции как активную форму вовлечения накопленного капитала в экономический процесс. В теории инвестиций их связь с накопленным капиталом (сбережениями) занимает центральное место. Это определяется сущностной природой капитала как экономического ресурса, предназначенного к инвестированию. Только путем инвестирования капитал как накопленная ценность вовлекается в экономический процесс.

Инвестиции как возможность использования накопленного капитала во всех альтернативных его формах. В инвестиционном процессе каждая из форм накопленного капитала имеет свой диапазон возможностей и специфику механизмов конкретного использования. Наиболее универсальной с позиций сферы использования в инвестиционном процессе является денежная форма капитала, которая для непосредственного применения в этом процессе требует в большинстве случаев его трансформации в иные формы. Капитал, накопленный в форме запаса конкретных материальных и нематериальных благ, готов к непосредственному участию в инвестиционном процессе, однако сфера его использования в таких формах имеет узко функциональное значение. 
Рассмотрим инвестиции в качестве вложения капитала в любые объекты хозяйственной деятельности. Инвестируемый предприятием капитал целенаправленно вкладывается в формирование имущества предприятия, предназначенного для осуществления различных форм его хозяйственной деятельности и производства различной продукции. При этом из обширного диапазона возможных объектов инвестирования капитала предприятие самостоятельно определяет приоритетные формы имущественных ценностей (объектов и инструментов инвестирования).

Инвестиции как источник генерирования эффекта предпринимательской деятельности. Целью инвестирования является достижение конкретного заранее предопределяемого эффекта, который может носить как экономический, так и внеэкономический характер (социальный, экологический и другие виды эффекта). К примеру, достижение экономического эффекта инвестиций определяется их потенциальной способностью генерировать доход. Как источник дохода инвестиции являются одним из важнейших средств формирования будущего благосостояния инвесторов. Вместе с тем, потенциальная способность инвестиций приносить доход не реализуется автоматически, а обеспечивается лишь в условиях эффективного выбора инвестиционных объектов (инструментов).

Инвестиции как объект собственности и распоряжения. Как объект предпринимательской деятельности инвестиции являются носителем прав собственности и распоряжения. Если на первоначальном этапе инвестирования капитала титул собственности и права распоряжения им были связаны с одним и тем же субъектом, то по мере дальнейшего экономического развития происходит постепенное их разделение. Инвестируемый капитал как объект собственности может выступать носителем всех форм этой собственности - индивидуальной частной, коллективной частной, муниципальной, общегосударственной и т.п. Инвестируемый капитал как объект распоряжения может выступать во всех разрешенных законодательством формах и видах этого распоряжения.

Инвестиции как объект временного предпочтения возникает в процессе инвестирования капитала, и непосредственно связан 


\section{П.П. Князев, М.Н. Клименко, Д.В. Моторнюк}

с фактором времени. С позиций этого фактора предназначенный к инвестированию капитал может рассматриваться как запас ранее накопленной экономической ценности с целью возможного ее приумножения в процессе инвестиционной деятельности, а с другой, - как задействованный экономический ресурс, способный увеличить объем потребления благ инвестора в любом интервале предстоящего периода. При этом экономическая ценность сегодняшних и будущих благ, связанных с инвестициями, для владельцев инвестируемого капитала неравнозначна. Экономическая наука считает, что сегодняшние блага всегда оцениваются индивидуумом выше благ будущих.

Между инвестированием капитала и получением инвестиционного дохода временной лаг может характеризоваться большим или меньшим интервалом. Соответственно перед инвестором всегда стоит альтернатива временного предпочтения использования капитала - избрать для инвестиционной деятельности кратко- или долгосрочные объекты (инструменты) инвестирования с соответственно дифференцированным уровнем инвестиционного дохода.

Риск является важнейшей характеристикой инвестиций, связанной со всеми их формами и видами. Поэтому инвестиции как носитель фактора риска одновременно выступают как источник дохода в предпринимательской деятельности инвестора.

Уровень риска инвестиций находится в прямой зависимости от уровня ожидаемой их доходности. Чем выше ожидаемый инвестором уровень доходности инвестиций в любой из их форм, тем выше (при прочих равных условиях) будет сопутствующий ему уровень риска и наоборот. Иными словами, объективная связь между уровнями доходности и риска инвестиций носит прямо пропорциональный характер.

Все формы и виды инвестиций характеризуются определенной ликвидностью, под которой понимается их способность быть реализованными при необходимости по своей реальной рыночной стоимости. Эта способность инвестиций обеспечивает высвобождение капитала, вложенного в разнообразные объекты и инструменты при наступлении неблагоприятных экономических и других условий его использования в определенной сфере предпринимательской деятельности, 
в отдельном сегменте рынка или в задействованном регионе. Ликвидность инвестиций является объективным фактором, обуславливающим выбор конкретных их форм и видов при прогнозировании необходимого уровня их предстоящей доходности.

Проведенный анализ наиболее существенных характеристик инвестиций показывает насколько многоаспектной и сложной с теоретических и прикладных позиций является эта экономическая категория. При этом все рассмотренные характеристики тесно взаимосвязаны и требуют комплексного отражения при определении их экономической сущности.

Рассмотрение основных характеристик экономической сущности инвестиций позволяет представить данную категорию как вложение капитала во всех его формах в различные объекты (инструменты) хозяйственной деятельности с целью получения прибыли, а также достижения иного экономического или внеэкономического эффекта, осуществление которого базируется на рыночных принципах и связано с факторами времени, риска и ликвидности.

В условиях развивающейся экономики важное значение имеет реальное инвестирование различных проектов и мероприятий, без которых немыслимы обновление и расширение основных производственных фондов во всех сферах национальной экономики. В целом, на современном этапе осуществление инвестиций следует рассматривать как необходимую форму деятельности предприятия, так как их отсутствие приводит к потерям конкурентных позиций субъекта хозяйствования.

Механизм осуществления инвестиций субъектами хозяйствования необходимо представить как инвестиционную деятельность. В теоретико-практическом аспекте инвестиционная деятельность представляет собой вложение инвестиций и осуществление практических действий в целях получения прибыли и достижения полезного общественного эффекта. Субъектами этого процесса выступают инвесторы, заказчики, исполнители работ, пользователи инвестиционных объектов, а также поставщики, юридические лица в виде коммерческих банков, страховых компаний, инвестиционных бирж и других участников инвестиционной деятельности. 


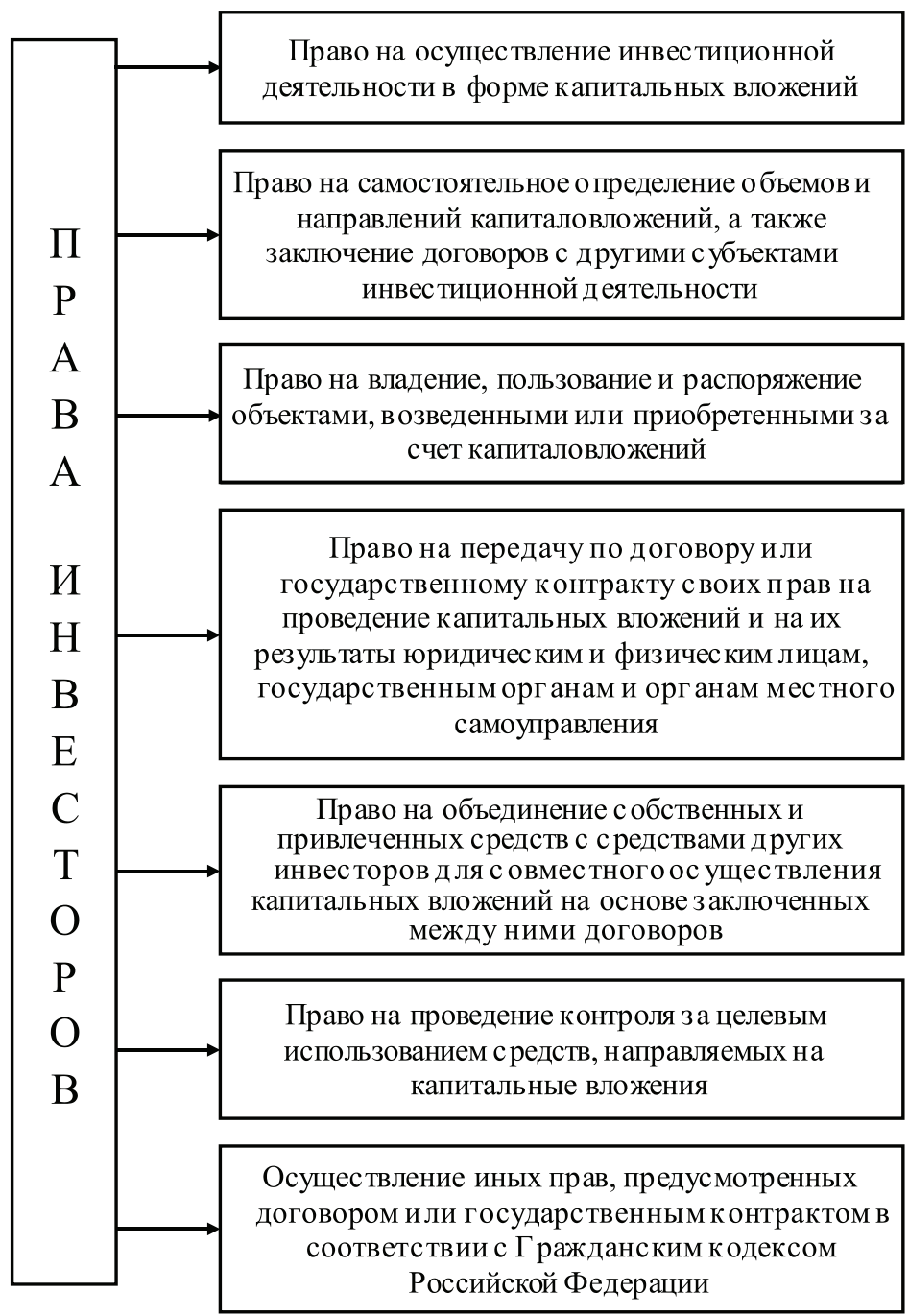

Рис. 3. Права инвесторов в Российской Федерации

В рамках данного учебного пособия более подробно дается характеристика инвесторов как носителей финансового интереса к осуществлению инвестиций. Инвесторы - субъекты инвестиционной деятельности, 
осуществляющие вложение собственных, заемных или привлеченных средств и обеспечивающие их целевое использование. В качестве инвесторов могут выступать: органы, уполномоченные управлять государственным имуществом или имущественными правами; предприятия и предпринимательские объединения; коммерческие банки, страховые компании и другие финансово-кредитные институты; национальные и иностранные физические и юридические лица; государства и международные организации. В соответствие с законодательным полем, действующим в России, все инвесторы обладают равными правами (рис. 3).

На основании проведенного теоретического исследования категорий «инвестиции» и «кредит» представим авторское определение инвестиционного кредита и инвестиционного кредитования.

Инвестиционный кредит - это экономические отношения между кредитором и заемщиком в форме движения ссудного капитала в денежном выражении, основанные на принципах срочности, платности, обеспеченности, дифференцированного подхода при кредитовании, осуществляемые в целях финансирования заемщиком вложений в различные объекты хозяйственной деятельности с целью достижения экономического или внеэкономического эффекта, осуществление которого базируется на рыночных принципах и связано с факторами времени, риска и ликвидности.

Инвестиционное кредитование - это взаимосвязанный комплекс документальных, организационно-технологических, информационно-юридических и финансовых процедур, составляющих целостный регламент взаимодействия коммерческого банка с заемщиком по поводу предоставления инвестиционных кредитов.

\section{2. Компдексная параметрадьная кдассификация инвестиций и кредита}

В рамках учебного пособия построим на основе анализа совокупной классификации кредита и инвестиций классификацию инвестиционного кредита.

Авторами при построении классификации кредита используется объектно-субъектный подход. В рамках этого подхода выделяются формы кредита, реализуемые в экономической системе. 
Выделение объектной позиции предполагает, что кредит может выступать в товарной и денежной формах. Кредит в товарной форме предполагает передачу во временное пользование стоимости в виде конкретной вещи, определенной родовыми признаками. В современной экономической системе преобладает денежная форма кредита. Он предоставляется и погашается денежными средствами.

При рассмотрении субъектной позиции кредит по форме представляется в зависимости от участников кредитных отношений - кредитора и заемщика. Так форма кредита определяется в зависимости от заемщика: государственная - заемщик государство при получении кредита на конкретный срок и определенных условиях; хозяйственная - заемщик предприятие при получении товарного, денежного и смешанного кредита; гражданская (личная) - заемщик физическое лицо; международная - зарубежный субъект хозяйствования; банковская - заемщики юридические и физические лица, банки.

Авторы считают целесообразным представить широко распространенное научно-теоретическое мнение о формах кредита. В современных условиях реализуются следующие формы кредита: коммерческий, банковский, государственный, потребительский, ипотечный, межбанковский, межхозяйственный, международный и др. (рис. 4).

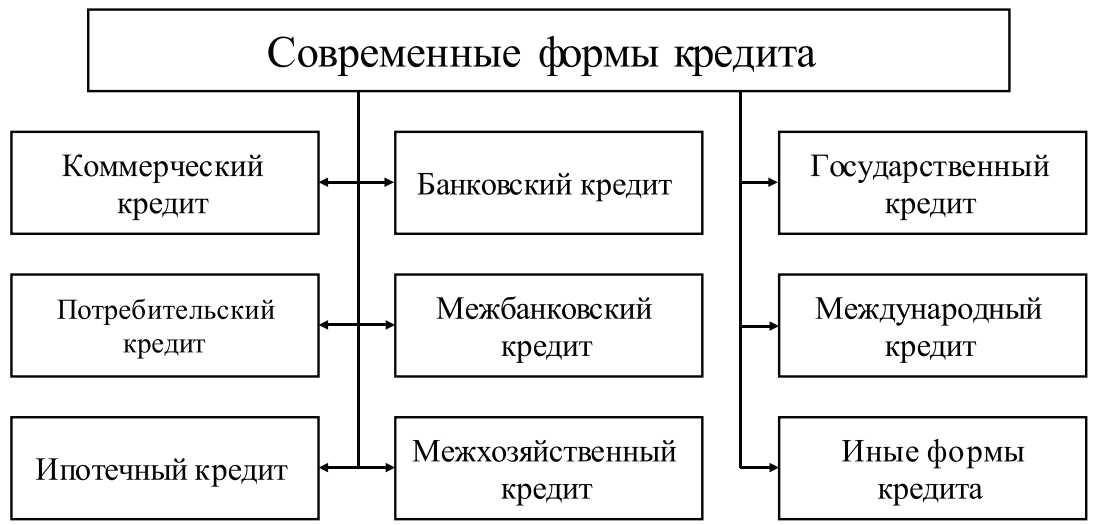

Рис. 4. Современные формы кредита 
Формы отличаются друг от друга составом участников, объектом ссуд, динамикой, величиной процента и сферой деятельности.

Раскроем содержание каждой формы кредита. Коммерческий кредит, предоставляемый в товарной форме продавцами товаров их покупателям в виде рассрочки платежа за товары или услуги. Коммерческий кредит выступает катализатором процесса реализации товара. Оформление коммерческого кредита традиционно - долговое обязательство - вексель, оплачиваемый через коммерческий банк.

Коммерческий кредит по объектной позиции является товарным капиталом, обслуживающим кругооборот промышленного капитала, движение товаров из сферы производства в сферу потребления. В субъектной позиции участниками становятся предприятия, получающие характеристику заемщика.

Широко распространенной формой является потребительский кредит. Он предоставляется торговыми компаниями, банками и специализированными кредитно-финансовыми институтами для приобретения населением товаров и услуг с рассрочкой платежа. Потребительский кредит может выступать как в денежной, так и в товарной форме.

Актуальное значение в современных условиях имеет ипотечный кредит. Его специфика проявляется через предоставление средств на приобретение, строительство жилья, покупку земли. Ипотечные кредиты предоставляют банки и целевые финансовые агентства, в том числе государственные.

В случае, когда субъектом выступает государство, возникает такая особая форма кредита - как государственный кредит. Эта форма кредита предполагает двойственное положение государства в субъектных отношениях: кредитор и заемщик. В последнем варианте государство или местные органы самоуправления пользуются государственным займом, реализуемым через кредитно-финансовые институты, прежде всего через Центральный банк. При этом происходит заимствование денежных средств на рынке капиталов для финансирования бюджетных расходов, бюджетного дефицита и других государственного задач. В качестве кредитора государство размещает кредитные ресурсы в социально значимые и ведущие отрасли национальной экономики. 


\section{П.П. Князев, М.Н. Клименко, Д.В. Моторнюк}

Взаимодействие между государствами и международными организациями охватывает совокупность экономических отношений, проявляющихся в форме международного кредита. Характеристика международного кредита отражается через движение ссудного капитала в сфере международных экономических и валютно-финансовых отношений. Посредством международного кредита происходит взаимодействие таких форм кредита как коммерческий и банковский.

Субъекты хозяйствования, к примеру юридические лица, предоставляющие и получающие во взаимных кредитных отношениях средства выступают участниками межхозяйственного кредита. Эта форма кредита имеет сходство с коммерческим кредитом. Однако, в отличие от коммерческого кредита, который носит в основном товарный характер, межхозяйственный кредит предполагает предоставление денежных средств. Такие кредиты в порядке оказания финансовой помощи могут получать предприятия при временных финансовых затруднениях или в целях развития от образующей структуры холдинга.

Аналогичным по степени взаимодействия субъектов является межбанковский кредит. Предоставление банками друг другу кредитных ресурсов происходит в случае наличия свободных средств у одного банка и потребности у другого банка в покрытии разрыва в ликвидности или необходимости увеличения объемов сделок. Следует отметить, что объемы рынка межбанковских кредитов в развитой экономике являются довольно существенными.

В рамках учебного пособия рассмотрим самую распространенную форму кредита - банковский кредит. По субъектной позиции осуществляется предоставление денежных средств коммерческими банками юридическим и физическим лицам, государству, нерезидентам. В формализованном аспекте банковский кредит превосходит объемы всех других форм кредита и имеет более широкую сферу применения.

Для целей построения классификации инвестиционного кредита - как разновидности банковского кредита, проведем классификацию банковского кредита по различным признакам (рис. 5, 6). 


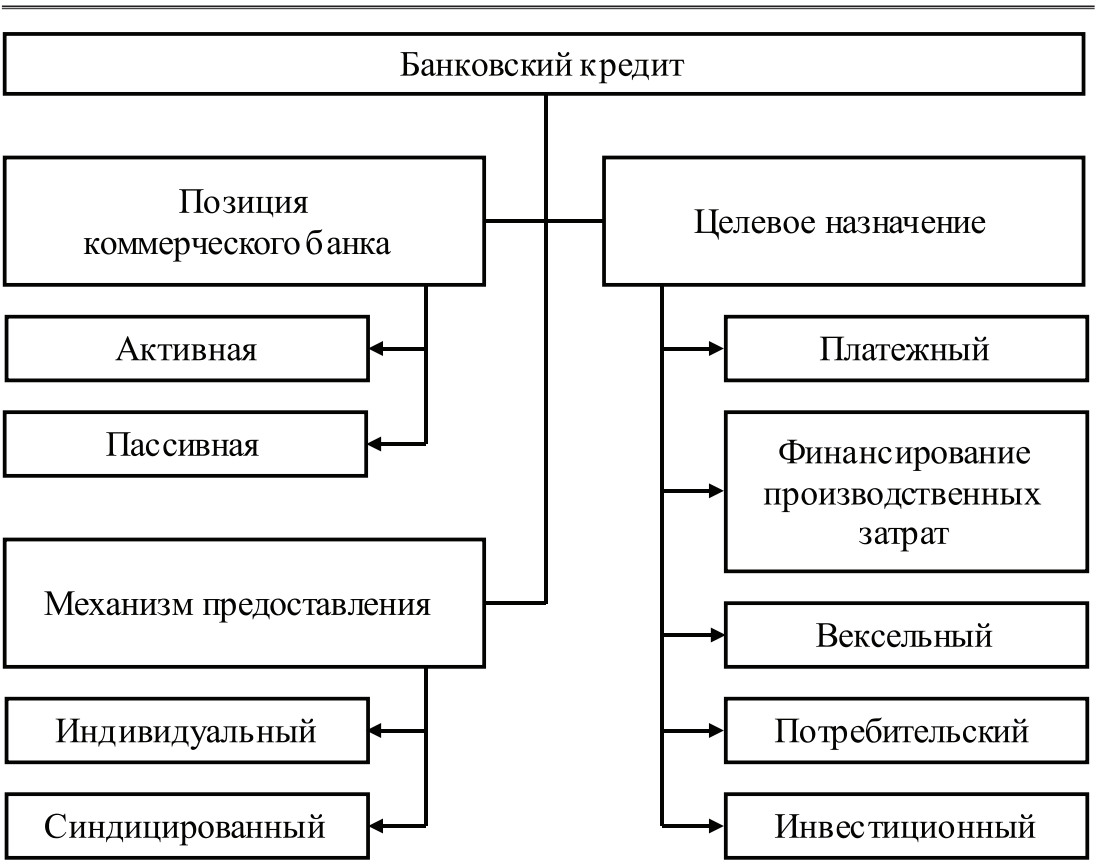

Рис. 5. Классификация банковского кредита по позиции банка, целевому назначению и механизму предоставления

По мнению авторов, деление банковского кредита - как формы, по специально установленным параметрам позволит выделить виды банковского кредита.

Критерий - позиция коммерческого банка предполагает установку активной или пассивной роли субъекта. При этом банковские кредиты подразделяются на активные и пассивные. В первом случае банк выступает кредитором, заемщиком выступают другие кредитные организации, юридические и физические лица. В пассивной позиции банк является заемщиком, к примеру, при межбанковском кредитовании.

По целевому критериальному назначению производится дифференциация банковских кредитов на определенные разновидности. К примеру, платежные - предназначены на проведение конкретной коммерческой сделки или на удовлетворение временной потребности клиента в денежных средствах. Так финансирование 
производственных затрат с помощью банковского кредита связывается с формированием запасов товарно-материальных ценностей и текущими производственными расходами.

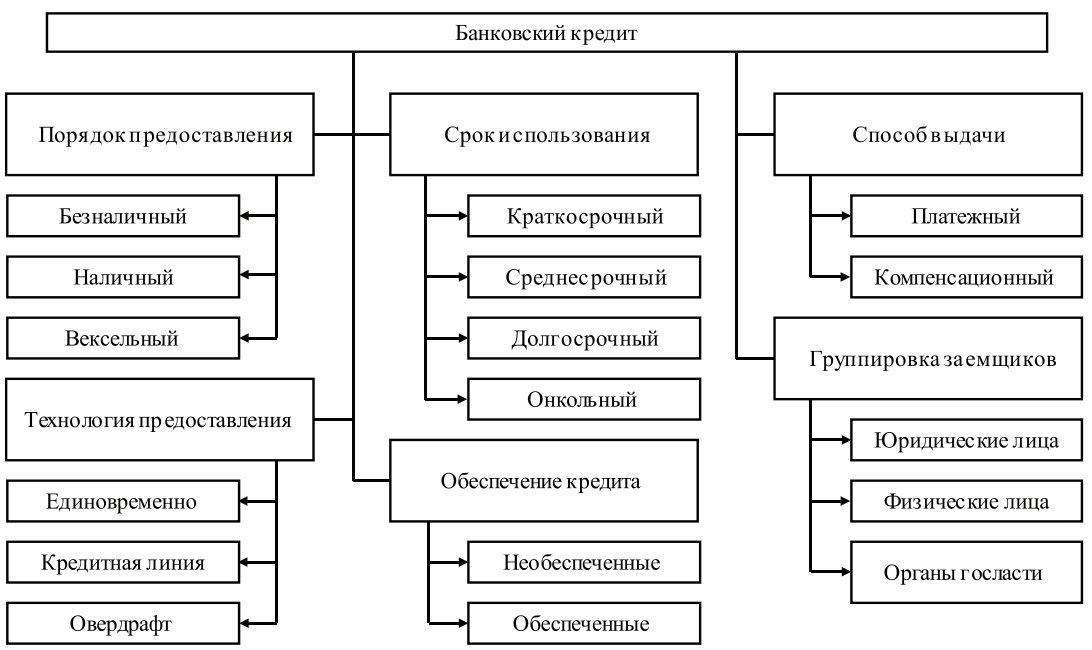

Рис. 6. Классификация банковского кредита по порядку и технологии предоставления, сроку использования, обеспечению кредита, способу выдачи, группировке заемщиков

Среди разновидностей банковского кредита по целевому назначению выделяются операции с векселями, включая операции репо, и потребительские кредиты. Инвестиционный кредит как вид банковского кредита ярко проявляется при связи кредита с движением капитала. По мнению авторов, оно разделяется на два типа: предоставление непосредственно денежных средств и приобретение ценных бумаг инвестиционного назначения. $\mathrm{C}$ помощью инвестиционного кредита происходит воспроизводство новой стоимости. Базовыми элементами которой должны быть возврат инвестиционного кредита, процентов за пользование кредитными ресурсами, а также формирование основы будущих доходов.

Выделение критерия - порядок предоставления банковского кредита предусматривает безналичное зачисление денег на соответствующий расчетный либо специальный транзитный счет заемщика. При 
кредитовании физических лиц широко распространено предоставление наличных денег. В определенных случаях банковский кредит оформляется векселями банка.

По технологическому критерию осуществляется предоставление кредитных ресурсов единовременно; в форме кредитной линии, носящей невозобновляемый либо возобновляемый характер; в форме овердрафтного кредитования счета.

По механизму предоставления банковский кредит рассматривается в индивидуальном порядке - при сотрудничестве банка с одним заемщиком, в синдицированном - при сотрудничестве банка с группой взаимосвязанных заемщиков, либо банковской группы с крупным заемщиком.

По критерию группировки заемщиков подразумевается совокупность кредитных отношений, когда банковский кредит может быть выдан хозяйствующему субъекту (юридические лица), населению (физические лица), государственным органам власти различного уровня.

Банковский кредит по критерию срока использования классифицируют на краткосрочный, среднесрочный и долгосрочный кредит. Раскроем содержание каждого из видов. Традиционно краткосрочные кредиты обслуживают текущие потребности заемщика, связанные с движением оборотного капитала. По международным стандартам краткосрочные кредиты не выходят за пределы одного года. Авторы поддерживают мнение, что краткосрочный кредит служит одним из источников образования и движения оборотного капитала предприятий. Среднесрочные (от 1 года до 3 лет) и долгосрочные (свыше 3 лет) банковские кредиты обслуживают долговременные потребности, обусловленные необходимостью модернизации производства, расширения и диверсификации бизнеса. В современных условиях существует вид банковского кредита особой срочности - онкольный кредит (от англ. money of call - кредит до востребования), который погашается по первому требованию. Данный банковский кредит предоставляется активным участникам финансового рынка.

По критерию обеспеченности банковские кредиты могут быть классифицированы на необеспеченные (бланковые) кредиты и обеспеченные. Последние, в свою очередь, подразделяются на залоговые, гарантированные и застрахованные, учитывая характер обеспечения. 


\section{П.П. Князев, М.Н. Клименко, Д.В. Моторнюк}

По способу выдачи банковские ссуды разграничиваются на ссуды компенсационные и платежные. В первом случае кредит направляется на расчетный счет заемщика для возмещения последнему его собственных средств, вложенных либо в товарно-материальные ценности, либо в затраты. Во втором случае банковская ссуда направляется непосредственно на оплату расчетно-денежных документов, предъявляемых заемщику к оплате по кредитуемым мероприятиям.

Таким образом, в результате проведенных классификационных мероприятий, авторы выделяют инвестиционный кредит в качестве банковского кредита, имеющего целевое назначение. С позиции коммерческого банка относящегося к активным операциям. По механизму предоставления предполагающего возможность индивидуального и синдицированного предоставления кредита. По способу выдачи в качестве платежного и компенсационного, направленного на возмещение ранее понесенных инвестиционных затрат. Традиционно инвестиционный кредит по порядку предоставления безналичный. Одновременно по технологии предоставления выделяется единовременно или в виде кредитной линии. По сроку использования инвестиционный кредит имеет долгосрочную характеристику с определенным уровнем обеспечения. Групповое распределение заемщиков при инвестиционном кредите реализуется через взаимодействие коммерческого банка с государством и юридическими лицами.

В целях определения дополнительных признаков инвестиционного кредита необходимо рассмотреть классификацию инвестиций (рис. 7, 8).

Инвестиции в объекты предпринимательской деятельности или во вне экономическую сферу осуществляются с использованием различных механизмов и способов. Определенных форм инвестиции в отличие от кредита не имеют. В рамках учебного пособия будет проанализирована классификация инвестиций, в которой зафиксированы общепринятые в экономической науке признаки.

По мнению авторов, в основу классификации инвестиций целесообразно внедрить объектно-субъектный подход. Это обеспечит распределение признаков относящихся к описанию объектов или субъектов инвестирования, что в свою очередь позволит внести смысловую значимость в классификацию инвестиционного кредита. 


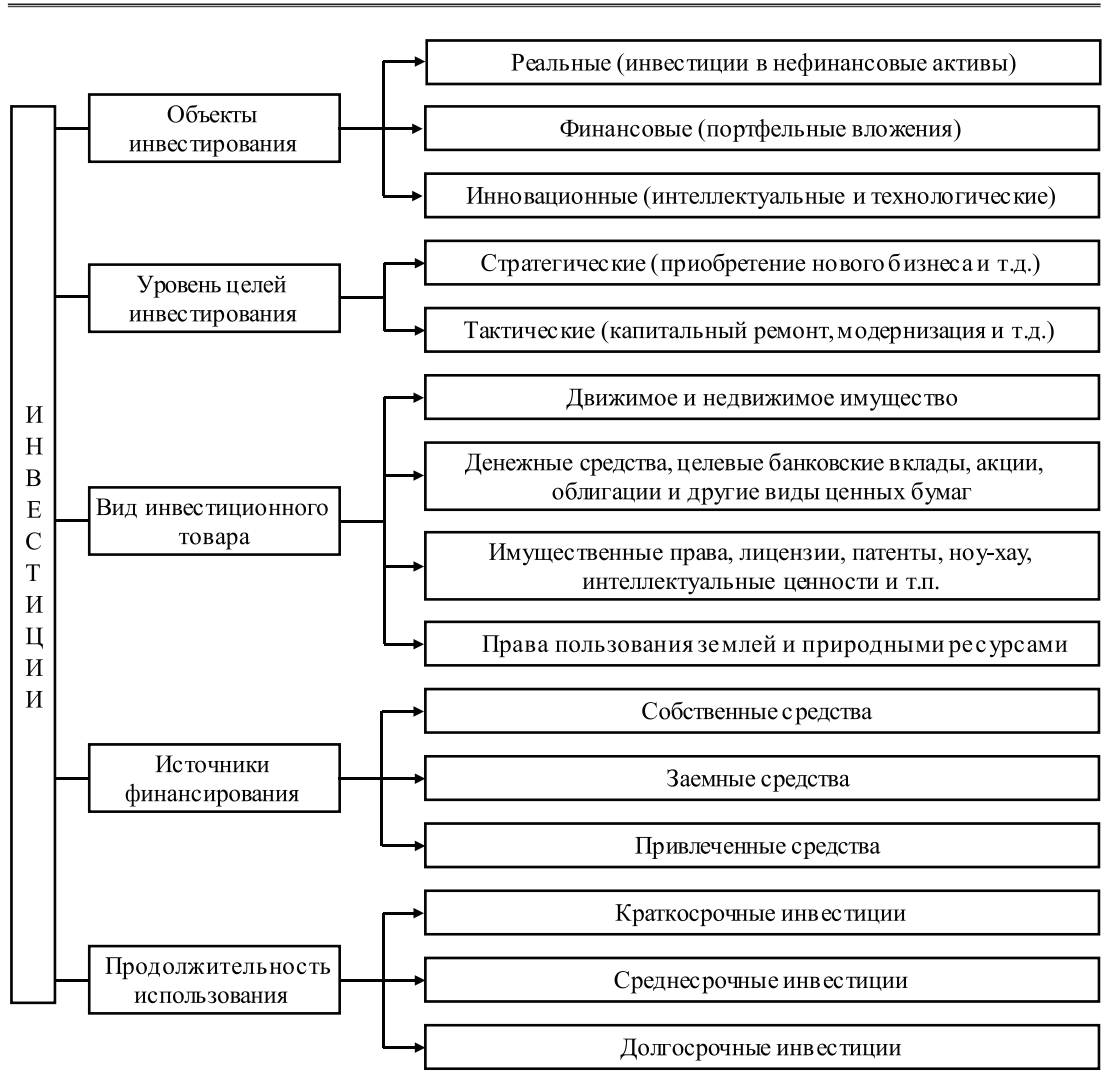

Рис. 7. Классификация инвестиций по объекту инвестирования, уровню целей, виду инвестиционного товара, источникам финансирования, продолжительности использования

Рассмотрим классификацию инвестиций в соответствии со следующим общепринятым в экономической науке набором классификационных признаков: объекты инвестирования; направление инвестирования; уровень целей; вид инвестиционного товара; субъекты инвестирования; источники финансирования инвестиций; статус инвестора; период инвестирования; хронологический признак; уровень риска; региональный характер инвестиций; механизм участия в инвестировании; дополнительные классификационные признаки. В ходе 
анализа и построения классификации первоначально будут изучены признаки имеющие объектную составляющую.

По критерию объекта инвестирования дифференцируют инвестиции на: реальные (инвестиции в нефинансовые активы), финансовые (портфельные вложения) и инновационные (интеллектуальные и технологические).

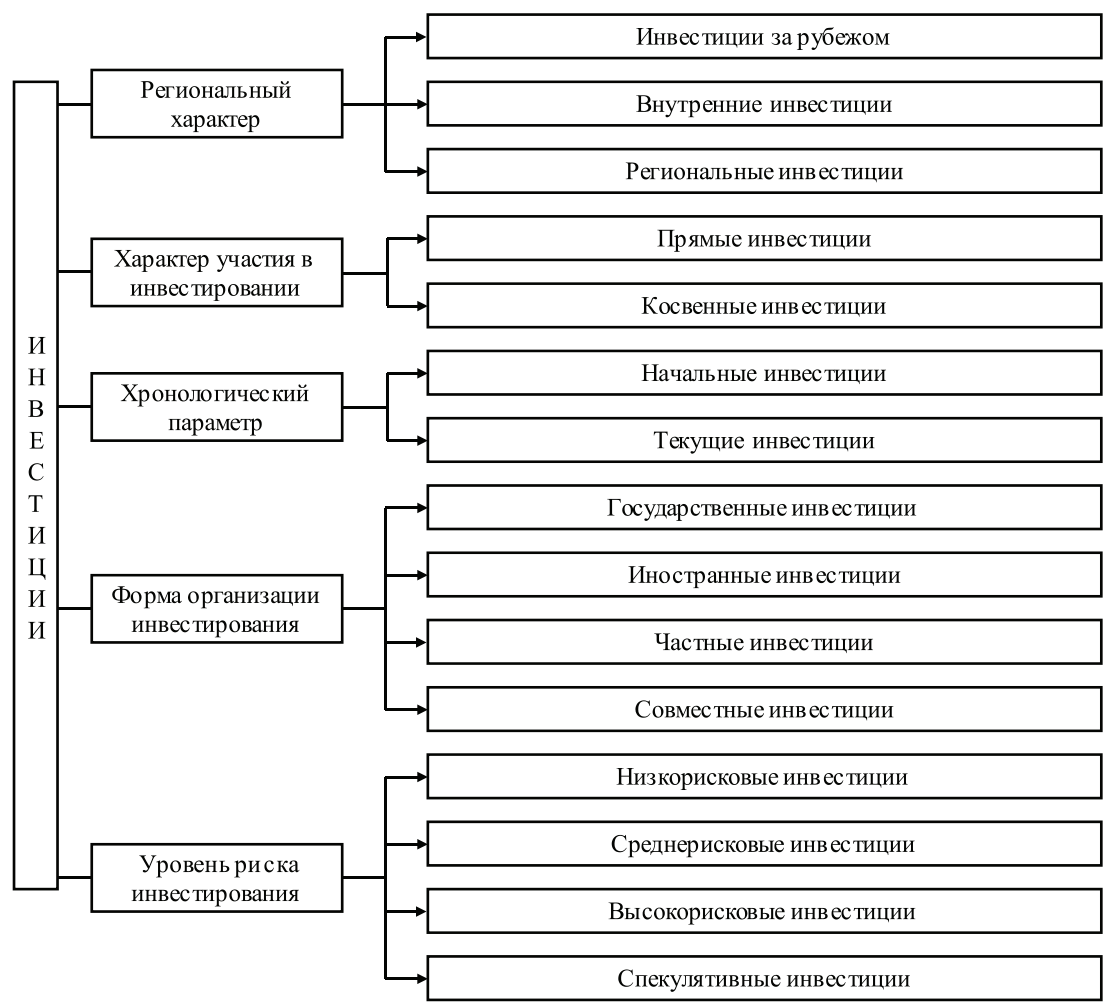

Рис. 8. Классификация инвестиций по региональному характеру, характеру участия в инвестировании, хронологическому параметру, форме организации инвестирования, уровню риска инвестирования

В качестве реальных представляются инвестиции, осуществляемые в виде вложений в основной капитал, в приобретение нематериальных активов (патенты, лицензии, программные продукты и т.д.), 
в прирост запасов материальных оборотных средств, в приобретение недвижимого имущества, земельных участков и объектов природопользования, в затраты на капитальный ремонт. Для этих целей могут быть использованы различные по источнику финансирования средства. Инвестиции в нефинансовые активы связаны с приобретением или созданием элементов основного капитала и осуществляются, как правило, в рамках инвестиционного проекта. В последнем случае инвестором становится коммерческий банк, осуществляющий кредитные вложения в конкретный проект.

На современном этапе реальные инвестиции (инвестиции в нефинансовые активы) осуществляются главным образом в форме капитальных вложений. Они представляют собой совокупность затрат на приобретение и создание основных средств с целью обновления и расширения производственного потенциала предприятий. Весомую долю имеют реальные инвестиции в нематериальные активы, которые включают приобретение патентов, торговых марок, товарных знаков, программных продуктов, ноу-хау, прав пользования земельными участками, объектами природопользования и т.д.

Рассмотрим реальные инвестиции - как вложения в прирост материально-производственных запасов - это средства определяемые затратами, которые состоят из поступлений оборотных средств в запасы и их выбытия. Они устанавливаются как разница между поступлениями оборотных средств в запасы и изъятиями из них. В экономической науке существует мнение о том, что инвестиции не могут выступать источником средств для приобретения материально-производственных запасов. Однако, по мнению авторов, это точка зрения является недостаточно практичной к применению. Это объясняется тем, что независимо от конкретных условий, в инвестиционном проекте, особенно если он связан с организацией какого-либо производства товаров или услуг, в обязательном порядке существует статья расходов на приобретение оборотных средств. В дальнейшем действующее производство будет самостоятельно обеспечивать наличие необходимого объема оборотного капитала, но начальном этапе эту роль играют инвестиционные ресурсы. 


\section{П.П. Князев, М.Н. Клименко, Д.В. Моторнюк}

В составе реальных инвестиций выделяются вложения в прочие нефинансовые активы, которые выражают затраты на приобретение земельных участков и объектов природопользования.

Определяя реальные инвестиции как источник осуществления капитального ремонта, следует отметить, что последний классифицируют на ремонт активной части основных средств (машин, оборудования и транспортных средств) и пассивной части (зданий и сооружений). Капитальным ремонтом активной части основных средств выступает вид ремонта, при котором производят, как правило, полную разборку агрегата, замену и восстановление изношенных деталей и узлов, ремонт базовых и других деталей и узлов, сборку, регулирование и испытание агрегата. При капитальном ремонте зданий и сооружений производится замена изношенных конструкций и деталей на более прочные и экономичные, повышающие эксплуатационные возможности ремонтируемого объекта, кроме полной замены стен, фундаментов, междуэтажных перекрытий и др.

Реальные инвестиции (инвестиции в нефинансовые активы) можно дополнительно классифицировать по следующим признакам: отраслевая структура; воспроизводственная структура; технологическая структура; назначение - по объектам производственного и социально-культурного назначения.

Рассматривая отраслевую структуру, по мнению авторов, делается акцент на определение долевой составляющей текущего уровня использования инвестиционных ресурсов в различных отраслях народного хозяйства - в промышленности, сельском хозяйстве, транспорте, связи, торговле и т.д., в целях изучения инвестиционной привлекательности или регулирования, в том числе на государственном уровне.

При использовании в качестве критерия воспроизводственную структуру реальные инвестиции можно характеризовать как капиталовложения, направляемые на новое строительство, расширение, реконструкцию и техническое перевооружение действующих предприятий. Отнесение к соответствующим направлениям воспроизводственной структуры проводится по масштабам и условиям строительства, которые определены проектно-сметной документацией. С учетом указанных параметров к новому строительству относят 
сооружение комплекса объектов основного, подсобного и обслуживающего назначения вновь создаваемых предприятий, зданий, а также филиалов и отдельных производств, которые после ввода в эксплуатацию будут находиться на самостоятельном балансе, осуществляемое на площадках для создания новой производственной мощности. Зачастую в практике инвестиционной деятельности встречаются случаи, когда строительство предприятия или сооружения предполагают осуществлять очередями. В данном варианте к новому строительству относят первую и последующие очереди до сдачи в эксплуатацию всех проектных мощностей на полное развитие предприятия (сооружения). По мнению авторов, к новому строительству необходимо относить также строительство на текущей площадке предприятия большей мощности взамен ликвидируемого, дальнейшая эксплуатация которого по техническим параметрам, экономическим составляющим и экологическим условиям определяется как нецелесообразная.

Анализируя составляющие воспроизводственной структуры реальных инвестиций, расширение действующих предприятий представляет собой строительство новых производств на существующих предприятиях (сооружениях), а также строительство новых и расширение функционирующих отдельных цехов или объектов основного, подсобного и обслуживающего назначения на территории действующих предприятий или примыкающих к ним площадках для создания дополнительных или новых производственных мощностей. Процессом расширения действующих предприятий является также создание филиалов и производств, входящих в их состав, которые после ввода их в действие не будут находиться на самостоятельном финансовом и бухгалтерском учете. По мнению авторов, при расширении действующего хозяйствующего субъекта увеличение производственной мощности осуществляется в сроки и при удельных капитальных затратах меньших по сравнению с новым строительством.

Реальные инвестиции на действующем предприятии осуществляются также в целях проведения реконструкции, т.е. переустройства существующих цехов и объектов основного, подсобного и обслуживающего назначения, как правило, без расширения существующих 


\section{П.П. Князев, М.Н. Клименко, Д.В. Моторнюк}

зданий и сооружений основного назначения. Процедура реконструкции связана с совершенствованием производственного процесса и необходима для увеличения его общего технико-экономического уровня.

Последним критерием, определяющим воспроизводственную структуру реальных инвестиций, является техническое перевооружение. Данный процесс предполагает выполнение комплекса мероприятий по повышению технико-экономического уровня отдельных производств, цехов и участков на основе внедрения современных технологий, модернизации и замены устаревшего и физически изношенного оборудования новым, более производительным, а также по совершенствованию подсобного и вспомогательного хозяйства.

Рассмотрим реальные инвестиции с точки зрения их технологической структуры. Инвестиционные затраты в этом смысле осуществляются в целях полного замещения используемых в производственном процессе основных технологий. В данном случае речь не идет о применении сопутствующих более современных технологий, которое осуществляется при техническом перевооружении.

В рамках последнего критерия дополнительной классификации реальные инвестиции (вложения в нефинансовые активы) могут осуществляться не только на воспроизводственные или технологические нужды. При переходе к цивилизованным правилам и методам ведения бизнеса, а также с учетом социальной ответственности, хозяйствующие субъекты могут направлять инвестиционные ресурсы в социально-культурную сферу или на благотворительные цели.

По мнению авторов, к реальным инвестициям нельзя относить инвестиции инновационного характера, которые на прямую не связаны с созданием материальных благ, а выражают вложения средств в подготовку и переподготовку кадров, проведение научно-исследовательских и опытно-конструкторских работ, создание промышленных образцов новой продукции и др. При этом речь может идти только о повышении уровня знаний специалистов предприятия или его научно-технического потенциала по сравнению с другими организациями. Подобные вложения в неосязаемые активы целесообразно выделить в самостоятельную группу инновационных инвестиций, а все вложения, осуществляемые для повышения уровня знаний, 
включить в подгруппу интеллектуальных инвестиций, вложения в НИОКР - технологических инвестиций.

В качестве финансовых инвестиций (портфельных вложений) определяются вложения средств в различные финансовые инструменты (активы). Последними могут выступать: ценные бумаги различных обществ, государственные и муниципальные ценные бумаги, ипотечные ценные бумаги, производные ценные бумаги. Более точно конкретизировать финансовые инвестиции, по мнению авторов, можно в виде вложений в ценные бумаги и уставные капиталы других хозяйствующих субъектов. Совокупные вложения в несколько видов финансовых инструментов (активов) представляются как портфельные инвестиции. В данном случае приоритетной целью субъектов инвестирования, в частности инвестора, является формирование такого набора финансовых активов (портфеля инвестиций), который носит оптимальный характер с точки зрения риска и дохода. Вторичной целью выступает управление этим набором в процессе проведения операций с финансовыми активами.

По критерию уровень целей инвестиции делятся на тактические и стратегические. Определяя целевую направленность инвестиций, осуществляемых хозяйствующим субъектом, стратегические цели инвестирования заключаются в улучшении конкурентоспособности предприятия. Это достигается путем покупки нового бизнеса и оборудования для них, а также расширением существующего направления деятельности через обновление оборудования или выход на другие рынка сбыта производимой продукции. В рамках выполнения стратегических целей возможно формирование холдинговых структур, носящих финансовый, промышленный или смешанный характер. Постановка стратегических целей инвестирования, по мнению авторов, необходима для любой динамично развивающейся компании. На основе проведенной градации выполнение тактических целей инвестирования необходимо для поддержания производственных мощностей хозяйствующего субъекта на существующем уровне путем технического перевооружения или капитального ремонта.

Выделение такого критерия как вид инвестиционного товара необходим для более точного определения экономического выражения 
того актива, в приобретение которого вкладываются инвестиционные ресурсы. В этой связи инвестиции на основе указанного критерия можно классифицировать на вложения в имущество, денежные средства и обязательства, выраженные в денежных единицах, имущественные права и права временного пользования.

Как отмечалось ранее, инвестиции могут осуществляться из различных источников. По критерию источник финансирования, инвестиции подразделяются на вложения за счет собственных средств хозяйствующих субъектов, то есть чистой прибыли, амортизации и т. п.; за счет заемных средств, то есть кредитных ресурсов, лизинга, средств полученных в займ и т.д.; за счет привлеченных средств, то есть средств вновь вовлекаемых учредителей (собственников) в осуществление различного рода инвестиционных проектов совместно с другими субъектами.

Рассматривая такой важный компонент процесса инвестирования как использование вложенных ресурсов, инвестиции можно классифицировать на кратко-, средне- и долгосрочные. Под краткосрочными инвестициями следует понимать вложения капитала на период не более одного года. К среднесрочным инвестициям могут быть отнесены вложения сроком до трех, а в отдельных случаях и до пяти лет. Под долгосрочными инвестициями, по мнению авторов, следует понимать вложения капитала свыше пяти лет в рамках инвестиционной программы, которая предполагает реализацию последовательных или связанных инвестиционных проектов.

По критерию региональный характер инвестиции классифицируются на инвестиции за рубежом, внутренние и региональные инвестиции. Руководствуясь данным признаком, инвестиции за рубежом можно представить как вложение средств в объекты инвестирования, размещенные за пределами государственных границ данной страны, или в дочерние структуры иностранных компаний, осуществляющих свою деятельность на ее территории. Принимая во внимание региональный аспект, внутренние инвестиции выражаются вложением средств в объекты инвестирования, размещенные на территории данной страны, а региональные инвестиции - соответственно в пределах конкретного региона государства. Использование данного 
классификационного признака, по мнению авторов, позволяет выделить основные направления инвестиционной деятельности, которые необходимы потенциальным инвесторам и государственным структурам в качестве информационного ресурса, а коммерческим банкам - как способа выбора необходимого банковского инструмента. Однако следует отметить, что подобное деление не учитывает ряда специфических черт инвестиционного процесса и не оказывает существенного влияния на процесс оценки эффективности и целесообразности инвестиций.

Рассмотрим такой критерий как характер участия в инвестировании. При использовании данного признака инвестиции классифицируются на прямые и косвенные. Под прямым участием в инвестировании понимается непосредственное участие потенциального инвестора в выборе объектов инвестирования и в механизме вложения средств. В рамках современного аспекта функционирования инвестиционного механизма под косвенным участием в инвестировании следует понимать вложение, осуществляемое инвестиционными или иными финансовыми посредниками. Последние аккумулируют и размещают привлеченные инвестиционные ресурсы по своему усмотрению, обеспечивая их эффективное использование путем выбора оптимальных объектов инвестирования и последующего управления ими.

При использовании в качестве критерия хронологический параметр, инвестиции делятся на начальные и текущие. Принимая во внимание стадию жизненного цикла хозяйствующего субъекта, начальные инвестиции представляют собой вложения, направленные на создание или сооружение нового объекта. В свою очередь к текущим, относятся инвестиции, осуществляемые в целях поддержания технико-экономического уровня существующего предприятия. По мнению авторов, выделение подобного признака помогает потенциальному инвестору с точки зрения выбора инструментов и технологий определения эффективности инвестиций, в том числе для определения общей целесообразности вложения средств.

По критерию форма организации инвестирования инвестиции выделяются государственные, иностранные, частные и совместные инвестиции. Под государственными инвестициями понимаются 
вложения, осуществляемые государственными органами власти различных уровней за счет соответствующих целевых бюджетов, внебюджетных фондов и заемных средств, а также реализуемые предприятиями государственной формы собственности (полной или частичной) за счет средств из различных источников. Иностранные инвестиции представляют собой вложения, осуществляемые иностранными субъектами на территории государства: юридическими и физическими лицами, а также непосредственно иностранными государствами и международными валютно-кредитными и финансовыми институтами. Частные инвестиции - вложения, осуществляемые физическими лицами и юридическими лицами негосударственной формы собственности. По мнению авторов, классификацию по критерию субъекта инвестирования необходимо, руководствуясь современным аспектом, следует дополнить совместными инвестициями, которые определяются как вложения, осуществляемые совместно отечественными и иностранными инвесторами. При чем в данном контексте инвесторами могут выступать государства, а также юридические и физические лица.

Последним критерием классификации инвестиций является уровень инвестиционного риска. В соответствие с этим признаком выделяют: безрисковые, низкорисковые, среднерисковые, высокорисковые и спекулятивные инвестиции. В экономической науке принято считать, что абсолютно безрисковых инвестиций не существуют. Однако, в данном случае под ними понимаются вложения средств в такие объекты инвестирования, по которым отсутствует реальный риск потери ожидаемого дохода или капитала и практически гарантируется получение прибыли, т. е. приносящие стабильный доход и не подверженные влиянию негативных факторов на макро- и микроуровнях. В качестве низкорисковых инвестиций определяются вложения капитала в объекты, риск по которым ниже среднерыночного уровня. Соответственно среднерисковые инвестиции характеризуют вложения капитала в объекты, риск по которым соответствует среднерыночному уровню, а высокорисковые инвестиции определяются тем, что уровень риска по объектам данной группы обычно выше среднерыночного. В экономической литературе можно встретить второе 
определение высокорисковых инвестиций - венчурные инвестиции, т.е. вложения в форме венчурного финансирования различного рода наукоемких исследований. Последним видом являются спекулятивные инвестиции, которые выражают вложения капитала в наиболее рисковые активы (например, в акции недавно созданных компаний), где ожидают получение максимального дохода (например, в ценные бумаги компаний, разрабатывающих и внедряющих высокие технологии).

В учебном пособии были рассмотрены основные признаки классификации инвестиций. Следует отметить, что можно использовать и дополнительные признаки: по использованию в инвестиционном процессе ограниченных ресурсов; по масштабам инвестирования; по степени подверженности влиянию других инвестиций; по форме получения эффекта, которая зависит от целей инвестирования; по функциональной деятельности, с которой наиболее тесно связаны инвестиции; по отраслевой классификации; по степени обязательности осуществления и т.д.

В целях полного представления классификации инвестиций необходимо, используя субъектный подход, определить субъект инвестирования. На современном этапе субъектами инвестиционной деятельности являются инвесторы, инициаторы (заказчики) проектов, подрядчики (исполнители) проектов, пользователи объектов, граждане и финансовые посредники. Данную группу субъектов можно классифицировать по самостоятельным признакам:

1. По направлениям текущей (эксплуатационной) деятельности - институциональные и индивидуальные инвесторы. В роли институциональных инвесторов выступают акционерные общества в сфере промышленности, торговли, транспорта, связи и т.д., индивидуальных - граждане.

2. По целям инвестирования выделяют стратегических и портфельных инвесторов. Первые ставят целью приобрести контрольные пакеты акций других компаний или большую долю в их уставном капитале для осуществления реального управления их деятельностью. Они осуществляют комплекс мероприятий по слиянию или поглощению других компаний. Портфельный инвестор вкладывает свой капитал в разнообразные финансовые инструменты с целью получения 
приемлемого текущего дохода (в форме дивидендов и процентов) или прироста капитала в будущем.

3. По принадлежности к институту резидентства выделяют отечественных и иностранных инвесторов.

В учебном пособии, опираясь на изучение классификации кредита и инвестиций в научно-экономических источниках, представим авторскую классификацию инвестиционного кредита на основе совокупных признаков (рис. 9, 10).

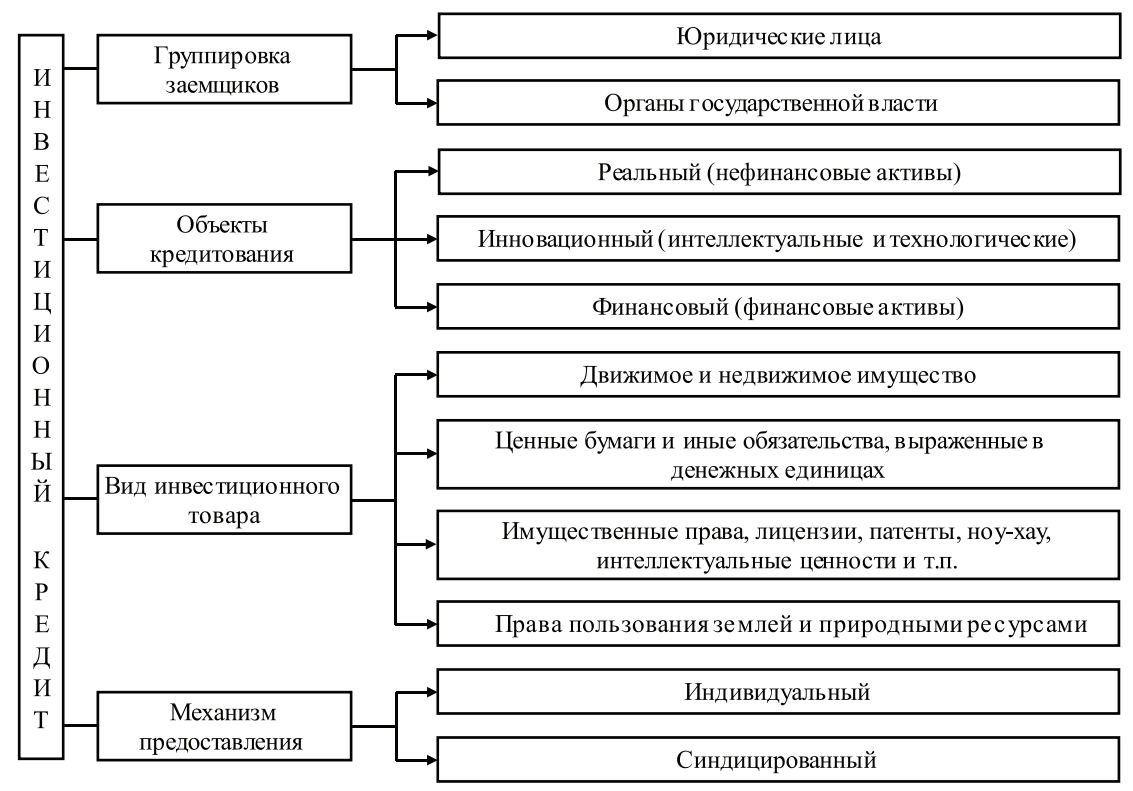

Рис. 9. Классификация инвестиционного кредита

по группировке заемщиков, объектам кредитования, виду инвестиционного товара, механизму предоставления

По критерию группировки заемщиков, наряду с категорией «кредит», подразумевается совокупность кредитных отношений, когда инвестиционный кредит может быть выдан хозяйствующему субъекту (юридические лица) и государственным органам власти различного уровня. В отличие от банковского, инвестиционный кредит не может быть предоставлен населению (физическим лицам). 


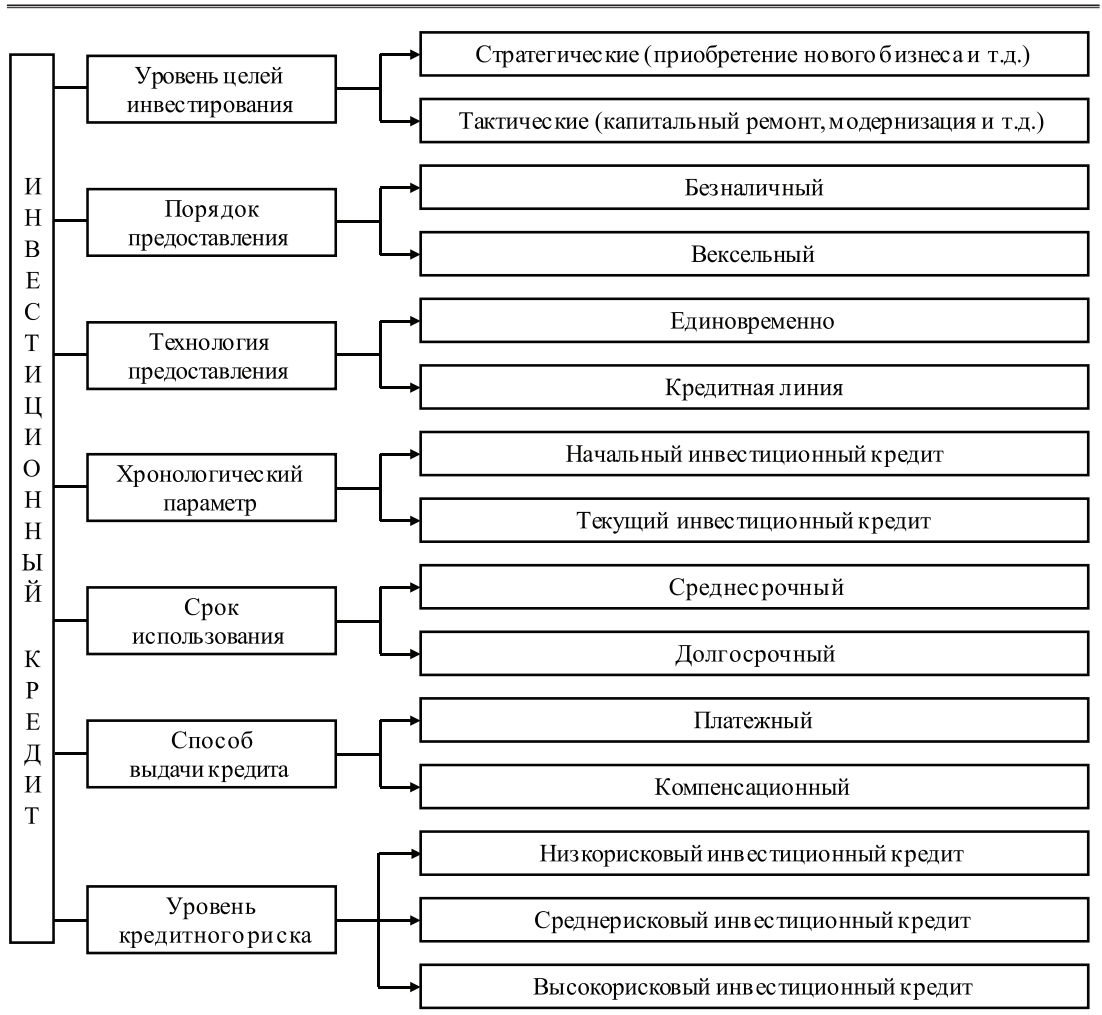

Рис. 10. Классификация инвестиционного кредита по уровню целей инвестирования, порядку и технологии предоставления, хронологическому параметру, сроку использования, способу выдачи кредита, уровню кредитного риска

Рассматривая критерий - объект кредитования, инвестиционный кредит классифицируется на: реальный инвестиционный кредит для приобретения нефинансовых активов; финансовый инвестиционный кредит для осуществления портфельных вложений; инновационный инвестиционный кредит, в рамках средств которого финансируются интеллектуальные и технологические мероприятия.

В качестве реальных определяются инвестиционные кредиты, предоставляемые для финансирования расходов по вложению в основной капитал, приобретение нематериальных активов 
(патенты, лицензии, программные продукты и т.д.), прирост запасов материальных оборотных средств, приобретение недвижимого имущества, земельных участков и объектов природопользования, затраты на капитальный ремонт и т.д. На современном этапе данные инвестиционные кредиты предоставляются с целью обновления и расширения производственного потенциала предприятий. Немаловажную роль играют инвестиционные кредиты, в рамках средств которых приобретаются патенты, торговые марки, товарные знаки, программные продукты, ноу-хау, права пользования земельными участками, объектами природопользования и иные нематериальные активы.

В отличие от инвестиций инвестиционный кредит может являться источником прироста материально-производственных запасов, т.е. оборотного капитала компании-заемщика. Это происходит на начальном этапе, т.е. на инвестиционной фазе, до тех пор, пока действующее производство не будет самостоятельно обеспечивать наличие необходимого объема данных ресурсов.

Инвестиционные кредиты инновационного характера предоставляются для целей вложения средств в подготовку и переподготовку кадров, проведение научно-исследовательских и опытно-конструкторских работ, создание промышленных образцов новой продукции и др.

В качестве финансовых инвестиционных кредитов выступают средства, предоставляемые для целей осуществления вложений в финансовые инструменты (активы), т.е. ценные бумаги и уставные капиталы других хозяйствующих субъектов. C позиции осуществляемых коммерческими банками на современном этапе активных операций, инвестиционные кредиты на инновационные цели предоставляются в Российской Федерации достаточно редко. Но с учетом международной практики следует ожидать развитие данного сегмента рынка банковского кредитования, как в количественном, так и качественном выражении.

Принимая во внимание высокие показатели рисков при предоставлении инвестиционных кредитов, необходимо выделить критерий - вид инвестиционного товара. По мнению авторов, данный 
критерий необходим для более точного определения экономического выражения того актива, в приобретение которого вкладываются кредитные ресурсы. В этой связи инвестиционные кредиты классифицируются на вложения в движимое и недвижимое имущество, ценные бумаги и иные обязательства, выраженные в денежных единицах, имущественные права, в т.ч. на интеллектуальную собственность, права временного пользования землей и природными ресурсами.

В рамках научно-теоретического обоснования важным критерием выступает механизм предоставления. По указанному критерию инвестиционный кредит классифицируется на индивидуальный и синдицированный. В первом случае вопрос о кредитовании рассматривается в индивидуальном порядке - при сотрудничестве банка с одним заемщиком. Во втором - при сотрудничестве банка с группой взаимосвязанных заемщиков, в большинстве случаев это холдинговые структуры, либо банковской группы с крупным заемщиком в целях финансирования крупного инвестиционного проекта, в т. ч. носящего государственную значимость.

Принимая во внимание различные целевые установки, которые определяют принятие решений в области использования заемных средств, значение приобретает критерий - уровень целей. При использовании данного признака инвестиционные кредиты делятся на тактические и стратегические. В связи с тем, что на период использования кредитных ресурсов заемщиком коммерческий банк играет роль инвестора, важное значение имеет уровень целей, которые устанавливают объекты вложений. Анализируя целевую направленность кредитных ресурсов, получаемых хозяйствующим субъектом в виде инвестиционного кредита, стратегические цели заключаются в покупке нового бизнеса (диверсификация) и оборудования для них, а также расширении существующего производства через обновление оборудования или выход на другие рынка сбыта производимой продукции. Выполнение тактических целей обосновываются необходимостью поддержания существующих производственных мощностей на фиксированном уровне путем технического перевооружения или капитального ремонта. 


\section{П.П. Князев, М.Н. Клименко, Д.В. Моторнюк}

Рассматривая форму предоставления инвестиционного кредита необходимо выделить критерий - порядок предоставления кредитных ресурсов, который предусматривает безналичное зачисление денег на соответствующий расчетный либо специальный транзитный счет заемщика или в определенных случаях оформление векселями банка. В условиях строгого целевого характера инвестиционный кредит не предоставляется в наличной форме.

Технология предоставления - как критерий классификации инвестиционного кредита, определяет предоставление кредитных ресурсов либо единовременно, т. е. при заключении кредитного договора, либо в форме кредитной линии, носящей невозобновляемый (без восстановления лимита кредитования) или возобновляемый характер (с возможностью восстановления лимита кредитования).

Анализируя временную составляющую процесса инвестирования различного рода ресурсов в объекты, необходимо принимать во внимание хронологический параметр данного процесса. По данному критерию инвестиционные кредиты делятся на начальные и текущие. В зависимости от стадии жизненного цикла хозяйствующего субъекта, начальные инвестиционные кредиты представляются для целей осуществления вложений, направленных на создание или сооружение нового объекта. В свою очередь к текущим инвестиционным кредитам относятся вложения, осуществляемые в целях поддержания технико-экономического уровня существующего производства хозяйствующего субъекта. Выделение подобного признака диктует коммерческому банку выбор инструментов и технологий определения эффективности инвестиций, в том числе для принятия решения об общей целесообразности вложения кредитных ресурсов.

Уделяя внимание значимости деятельности коммерческого банка как посредника в предоставлении кредита, следует определить следующий критерий классификации инвестиционного кредита - срок использования. По данному критерию инвестиционные кредиты делятся среднесрочные и долгосрочные. Среднесрочные инвестиционные кредиты предоставляются на срок до 3 лет, долгосрочные - на срок свыше 3 лет. Данная градация имеет важную роль при разработке коммерческим банком кредитной политики - 
как системы мероприятий по размещению средств, полученных в рамках проведения депозитной политики и управления активами банка. Традиционное понятие - краткосрочные кредиты, не применяется к инвестиционным кредитам. Краткосрочный характер может проявляться только в случае досрочного погашения обязательств перед банком.

Рассматривая процесс отслеживания целевого характера использования инвестиционного кредита, следует выделить критерий классификации - способ выдачи. В данном аспекте, инвестиционные кредиты разграничиваются на платежные и компенсационные. В первом случае кредитные ресурсы направляются непосредственно на оплату расчетно-денежных документов, предъявляемых заемщику к оплате по кредитуемым мероприятиям. Во втором - направляются на расчетный счет заемщика для возмещения последнему его собственных средств, вложенных осуществление расходов инвестиционного характера. Данный процесс в современной банковской практике носит определение возмещение ранее понесенных инвестиционных расходов.

Последним критерием классификации инвестиционного кредита является уровень кредитного риска. Классификацию по данному признаку можно осуществить на основе банковского законодательства. Однако, подобная классификация будет носить практический, а не научно-теоретический характер. В связи с этим, инвестиционные кредиты следует разделить на безрисковые, низкорисковые, среднерисковые, высокорисковые. В экономической науке принято считать, что абсолютно не подверженных кредитному риску кредитов не существуют. Однако, в данном случае под безрисковыми инвестиционными кредитами понимаются вложения средств в объекты инвестирования, которые не подвержены влиянию негативных факторов на макро- и микроуровнях. Примером могут служить инвестиционные кредиты, предоставляемые монополиям - ПАО «Газпром», ПАО «Роснефть» и т.д. В качестве низкорисковых инвестиционных кредитов определяются вложения в объекты, риск по которым ниже среднерыночного уровня, а также учитывается качество и ликвидность обеспечения. Соответственно, среднерисковые - характеризуют вложения в объекты, риск по которым соответствует среднерыночному уровню, и кредитование заемщика проводится впервые. 


\section{П.П. Князев, М.Н. Клименко, Д.В. Моторнюк}

Высокорисковые инвестиционные кредиты определяются тем, что уровень риска по объектам данной группы обычно выше среднерыночного, осуществляется кредитование крупного по масштабам инвестиционного проекта, работа с заемщиком проводится в первые и т.д. В современной мировой банковской практике встречаются случаи, когда коммерческий банк открывается дочернюю структуру, которая осуществляет венчурное финансирование. В данном случае, нельзя говорить о венчурном инвестиционном кредитовании, так как в большинстве случаев венчурная компания использует собственные, а не кредитные ресурсы банка-собственника, либо привлеченные средства с использованием делового статуса и имиджа банка.

В учебном пособии разработана и отображена классификация инвестиционного кредита по различным критериям. Использование данных научно-теоретических положений позволит банкам повысить эффективность инвестиционного кредитования и превратить данный вид активных операций в ведущие и наиболее перспективные для осуществления.

\section{3. Кредитование инвестиционных проектов в воспроизводственной структуре хозяйствования}

Инвестиционную активность в реальном секторе экономики, с позиции авторов, невозможно обеспечивать только за счет собственных ресурсов субъектов хозяйствования. Инвестиционное потребление требует привлечения дополнительных средств, что позволяет предприятию осуществить вложение в развитие или реконструкцию бизнеса.

В целях обозначения аспектного подхода и определения значимости операций инвестиционного кредитования в современной российской экономике необходимо изучить существующий механизм кредитования банками инвестиционных проектов. В учебном пособии будут представлены мероприятия по повышению эффективности операций инвестиционного кредитования - как перспективного банковского продукта.

Денежный поток адекватный реальным потребностям инвестиционного проекта формируется с помощью инструментов финансового 
конструирования. Финансовое конструирование - это процесс разработки финансовых инструментов, способствующих привлечению денежных средств в различных формах с целью осуществления инвестиционного проекта и достижения максимального экономического эффекта. В этой связи, по мнению авторов, инвестиционное кредитование является важным инструментом привлечения инвестиционных ресурсов.

С практической позиции не следует забывать, что основной идеей инвестиционного кредитования как банковского продукта, является получение доходов от инвестирования в создаваемое предприятие или реконструируемое производство с целью погашения задолженности и формирования прибыли банка. В мировой практике данное направление банковской деятельности играет важную роль в экономике стран и регионов, которые осуществляют расширение и модернизацию производственных мощностей капиталоемких отраслей промышленности. Основными целями инвестиционных проектов предприятий реального сектора являются осуществление крупных капитальных вложений в техническое перевооружение производства или создание новых конкурентоспособных производств. В условиях недостаточности средств у субъектов хозяйствования, актуальность приобретает развитие банковского кредитования реализации инвестиционных проектов. В данном контексте речь идет о развитии средне- и долгосрочного кредитования, являющегося для российских коммерческих банков делом как проблематичным, так и объективно перспективным.

Как банковский продукт - инвестиционное кредитование относительно новая форма заимствования средств для национального банковского сектора. Кредитование инвестиционных проектов возникло и развивалось из такого вида банковской практики, как кредитование с условием погашения кредита произведенной продукцией. Так, средства необходимые для разработки газовых и нефтяных месторождений, предоставлялись банками под запасы нефти, газа. Проценты за пользование кредитными ресурсами погашались начиная с первого месяца действия договора. Задолженность по основному долгу возмещалась по истечении инвестиционной фазы. К примеру, 


\section{П.П. Князев, М.Н. Клименко, Д.В. Моторнюк}

после начала добычи нефти и газа с момента ввода объекта в эксплуатацию за счет поступления от продаж.

Рассматривая данный процесс с позиции технологий осуществления банковских операций, следует отметить, что механизм инвестиционного кредитования широко используется в международной банковской практике. Так, Международный банк реконструкции и развития использует инвестиционное кредитование в сотрудничестве с государствами, которые обладают богатыми природными ресурсами, но испытывают недостаток капитала.

Мировая банковская практика располагает немалым опытом средне- и долгосрочного инвестиционного кредитования хозяйствующих субъектов. Банковские технологии осуществления данных операций находятся на высоком уровне, что в свою очередь позволяет не принимать во внимание платежеспособность и прочие характеристики организаций-инвесторов, если речь идет о нескольких инвесторах, вкладывающих средства в проект. В рамках практической составляющей банки проверяют инвесторов, чтобы выяснить, насколько они в состоянии поддержать проект, в том числе в долгосрочном аспекте. В дальнейшем показатели движения денежных средств (cash flow), включая разницу между поступлениями и платежами, не рассматриваются в качестве единственного критерия для финансирования. Важными звеньями при принятии инвестиционного решения являются гарантии ввода объекта в строй, начала его эксплуатации и последующего развития, субсидии на инвестиционной фазе, обязательства по обеспечению всеми ресурсами, гарантии по поставкам необходимой продукции третьими лицами. По мнению авторов, эти составляющие образуют сложное переплетение отношений между инвесторами, банками и другими участниками, которое дополнительно может трансформироваться с учетом масштаба проекта. Однако, эффективное структурирование возможно только при определенном минимальном объеме инвестиционных ресурсов.

Таким образом, в основу кредитования инвестиционных проектов с участием коммерческого банка заложена идея выполнения обязательств путем возврата кредитных ресурсов за счет доходов, которые принесет создаваемое или реконструируемое предприятие, 
т.е. объект инвестирования, в будущих периодах. Принимая во внимание данное положение, авторская позиция заключается в необходимости существования эффективного механизма инвестиционного кредитования в коммерческом банке.

На практике коммерческие банки, выступая в роли кредиторов, рассматривая вопросы использования механизма инвестиционного кредитования и участия в нем, принимают решения исходя из технической и экономической жизнеспособности предложенного инвестиционного проекта. При оценке проектов учитываются различные критерии. Набор данных критериев в зависимости от технологии конкретного коммерческого банка может отличаться от прочих. Однако, основными являются элементы, которые подтверждают, что:

- кредитный риск больше, чем капитальный или иные риски проекта;

- технико-экономическое обоснование или бизнес-план проекта составлены в удовлетворительной для коммерческого банка форме;

- гарантировано наличие источников и фиксированная стоимость используемых в проекте продукции и сырья;

- проект обеспечен топливно-энергетическими ресурсами по приемлемым ценам;

- существует рынок для будущего товара проекта, а транспортировка до рынка возможна по приемлемым ценам;

- строительные материалы можно приобрести по ожидаемым ценам;

- подрядчик, пользователь и управленческий персонал имеют достаточный для реализации опыт и обладают деловой репутацией;

- проект не включает неапробированную технологию;

- контракты между партнерами и другими заинтересованными сторонами заключены, а лицензии и разрешения получены;

- нет риска экспроприации, страховой и суверенный риски учтены;

- валютные риски, при их наличии, распределены среди участников проекта;

- основные инициаторы проекта сделали взносы в начальный капитал;

- обеспечено надлежащее качество поставляемых ресурсов и активов;

- предусмотрено соответствующее страховое покрытие; 


\section{П.П. Князев, М.Н. Клименко, Д.В. Моторнюк}

- учтен и распределен форс-мажорный риск, риски задержек (в поставках, строительстве и прочих) и роста издержек;

- проект будет иметь удовлетворяющие инвесторов итоговые показатели;

- реалистично спрогнозированы показатели инфляции и процентных ставок.

Обобщая указанные критерии, можно определить основные требования, предъявляемые потенциальными участниками в лице коммерческих банков к инвестиционному проекту.

Первым требованием является экономичность. Банковские критерии экономичности проекта проверяются на различных моделях денежных потоков (cash flow). При заключении сопутствующих договоров по вопросам строительства и финансирования инвесторы руководствуются и обосновывают свои планы собственными сценариями продолжительности строительства и соответствующих затрат, развития инфляции, размеров финансирования, эксплуатационных расходов и т.д. Понятно, что самостоятельная оценка коммерческим банком рисков не совпадает с прогнозами и выводами инвесторов. Для коммерческого банка инвестиционный проект должен быть оправдан и с учетом таких факторов развития, которые не всеми принимаются во внимание. При этом, по мнению авторов, основным является сохранение заинтересованности других инвесторов в реализации инвестиционного проекта и не спровоцировать прекращения их участия в нем до погашения всех обязательств перед коммерческим банком.

Рассмотрим следующее требование как общий интерес. При инвестиционном кредитовании период времени, в течение которого относительно точно могут прогнозироваться экономические результаты, всегда значительно короче, чем срок кредитов. Коммерческий банк учитывает это, с одной стороны, сформулировав рамочные показатели прогноза денежных потоков, чтобы создать экономически обоснованную возможность для последующего возврата кредитов, с другой - адекватно реагируя на обстоятельства, связанные с объединяющим всех участников интересом, т.е. с одинаковой в долгосрочном плане направленностью интересов всех участников инвестиционного проекта. По мнению авторов, в случае, когда подобная 
направленность интересов имеет место и достаточно стабильна, то коммерческий банк может участвовать в инвестиционном проекте.

Анализируя названные выше критерии, можно сделать вывод о том, что они дают основание для выделения основных принципов, необходимых для реализации инвестиционного проекта с участием коммерческого банка путем осуществления операций инвестиционного кредитования: жизнеспособность проекта; участие в проекте заинтересованных партнеров; учет и распределение всех рисков проекта; урегулирование правовых аспектов; разработка конкретных скоординированных планов действий и наличие качественного бизнес-плана реализации проекта.

Следует отметить, что особую роль при осуществлении инвестиционного кредитования российскими коммерческими банками играет распределение рисков между участниками проекта. Например, путем диверсификации или выставления различных гарантий. По мнению авторов, необходимо использовать международный опыт решения вопросов в данной сфере. Так, в мировой практике принято различать три основных вида инвестиционного кредитования - кредитование с правом полного, частичного и без права регресса. Рассмотрим каждый вид в отдельности.

Если коммерческому банку, который выступает в роли кредитора, удается сохранить за собой право полного регресса к инициатору относительно всех обязательств по инвестиционному проекту, то предоставленные на подобных условиях кредитные ресурсы приравниваются к обычному обеспеченному кредиту. В этом случае фактически не осуществляется разделение рисков, так как инициатор несет всю полноту ответственности по всем рискам инвестиционного проекта. По мнению авторов, данный подход к организации инвестиционного кредитования является наиболее целесообразным, в частности, когда инвестиционный проект небольшой по масштабам (не нуждается в дополнительных расходах) или выступает звеном инвестиционной программы.

Наибольшее распространение в международной практике получило инвестиционное кредитование с правом частичного регресса. В этом случае риски инвестиционного проекта распределяются 
между участниками таким образом, чтобы каждый риск был принят той стороной, которая бы смогла наилучшим образом провести его оценку и осуществить мероприятия по минимизации. По мнению авторов, объективным примером является структура распределения рисков, когда ответственность учредителей за погашение кредита распространялась лишь на период строительства и ввода объекта в действие, т.е. в инвестиционной фазе проекта, а кредиторы возьмут на себя все риски после того, как объект инвестирования начнет действовать.

Рассмотрим последний вид. При кредитовании проекта без права регресса кредиторы берут на себя полную ответственность за реализацию проекта. Этот вид инвестиционного кредитования отличается от прочих высокими ценовыми параметрами и редко встречается на практике. Вместе с тем, следует отметить, число инвестиционных проектов, кредитуемых в развитых странах без права регресса, увеличивается. По мнению авторов, это связано главным образом с ростом конкуренции среди финансовых институтов на рынке кредитно-инвестиционных продуктов, а также с совершенствованием методик разработки и повышением качества исполнения бизнес-планов параллельно с использованием эффективных и динамичных методов управления реализацией инвестиционных решений.

По мнению авторов, в настоящее время с учетом экономического развития и возможностей национальной банковской системы в Российской Федерации целесообразно развивать операции инвестиционного кредитования с правом частичного регресса.

При изучении субъектного подхода, следует отметить, что при инвестиционном кредитовании в качестве кредиторов могут выступать субъекты - коммерческие банки, предприятия, осуществляющие поставку, покупатели планируемой к производству продукции, государственные органы, пенсионные фонды, инвестиционные и лизинговые компании и прочие. В связи с этим, инвестиционное кредитование предоставляет объективную возможность использования нескольких источников заемного капитала, что нередко является необходимым условием реализации крупных инвестиционных проектов. При этом может быть получен доступ к источникам кредитных ресурсов, обладающим низкими ценовыми параметрами, например, 
таким, как средства международных финансовых рынков, государственные программы кредитования экспорта, долгосрочные кредиты иностранных банковских групп или Международного банка реконструкции и развития и т.д.

В разрезе практического функционирования привлечение расширенного круга потенциальных кредиторов способствует организации ими консорциума с выделением ведущего кредитора-агента, представляющего интересы всего сообщества. В подобном случае кредитные ресурсы обычно передаются специально создаваемой самостоятельной управляющей компании. По мнению авторов, это является основным преимуществом для учредителей (собственников), так как они получают кредитные ресурсы без отражения задолженности на своем балансе, поскольку она относится на баланс специальной компании. В этом случае кредит не ухудшает показатели финансового состояния учредителя - в связи с тем, что обязательства, как гарантия планомерного завершения строительства, залог и другие, обычно носящие временный характер, выделяются отдельной строкой за балансом учредителя и исчезают из него по истечении срока их действия.

Рассматривая положительные стороны инвестиционного кредитования, следует учитывать, что это продукт деятельности коммерческого банка. Принимая во внимание этот момент, необходимо отметить, что банк берет на себя часть рисков инвестиционного проекта, и тем самым обусловливает определенные особенности инвестиционного кредитования, которые с позиции учредителей (собственников) являются недостатками по сравнению с обычным кредитованием. Основной, по мнению авторов, особенностью является то, что стоимость инвестиционного кредитования выше стоимости обычного кредитования. Банковский процент за пользование инвестиционным кредитом складывается из рыночной процентной ставки, комиссий за обязательство предоставить кредит и за резервирование средств, а также из надбавки к базовой ставке процента за согласие банка взять на себя часть рисков проекта.

Изучая инвестиционное кредитование с позиции движения различного рода документов, можно выделить следующую особенность. В отличие от стандартного кредитования банк имеет право 


\section{П.П. Князев, М.Н. Клименко, Д.В. Моторнюк}

дополнительно запросить различную информацию об инвестиционном проекте. Среди которых могут быть: бизнес-план или техникоэкономическое обоснование; технические данные и параметры; расчеты прибыли, затрат, себестоимости продукции и т.п. Достаточно часто коммерческие банки требуют проведения экспертизы с привлечением независимых специалистов.

Рассматривая практический аспект осуществления операций инвестиционного кредитования, необходимо определить следующую особенность - наличие, качество и адекватный объем обеспечения. По мнению авторов, нахождение объективного решения и исключение существования данной проблемы предполагает решение совокупности взаимосвязанных задач. Наиболее важными из которых являются: необходимость получения четкого представления о вероятном изменении качества предмета обеспечения во времени; анализ возможности снижения стоимости предмета обеспечения; существование потенциальных сложностей с реализацией предмета обеспечения в случае невозврата кредитных ресурсов; необходимость учета объективной возможности заемщика предоставить качественное обеспечение в материальном виде и т.д.

Оценим, какую роль играет для банка обеспечение кредита. При проведении операций инвестиционного кредитования коммерческий банк должен руководствоваться более широкими, чем обычно принято при краткосрочном кредитовании, представлениями о видах обеспечения долгосрочных кредитов и их качестве. В качестве видов обеспечения, которые кредитор может принимать в расчет при принятии решения о выдаче долгосрочного кредита заемщику, образуют 2 группы. Рассмотрим эти группы обеспечения.

Группа первая - традиционные для банковской практики имущественные виды обеспечения. Они регулируются нормами Гражданского кодекса Российской Федерации. Согласно ст. 329 Кодекса, исполнение обязательств может обеспечиваться неустойкой, залогом, удержанием имущества должника, поручительством, банковской гарантией, задатком и другими способами, предусмотренными законом или договором. По мнению авторов, не все из перечисленных способов одинаково значимы, адекватны и объективны для обеспечения 
инвестиционных кредитов. Одновременно с этим, законодательное поле оставило субъектам кредитной сделки возможность использовать в качестве обеспечения и другие способы. Тем самым коммерческому банку фактически дается право разрабатывать и предлагать заемщикам различные подходы, позволяющие определить и получить обеспечение, которое повышало бы уверенность в целесообразности участия банка в финансировании инвестиционного проекта.

Вторая группа видов обеспечения, как правило, не может быть оценена конкретной денежной суммой, которую кредитор может получить в случае невозврата кредитных ресурсов или неполучения платы за пользование кредитом. Элементы данной группы можно назвать информационными видами обеспечения. Внутри данной группы можно выделить две подгруппы. Первая подгруппа - это известные в маркетинге и ценообразовании конкурентные преимущества, приобретенные заемщиком за период деятельности на рынке и которые в деловом аспекте рассматриваются как залог его будущих новых достижений. Вторая подгруппа - это сведения о реализации инвестиционного проекта, а именно информация о самом проекте; технико-экономическом обосновании инвестирования и различных проведенных технико-экономических исследованиях; результатах обследования заемщика специалистами коммерческого банка; результатах анализа бизнес-плана реализации инвестиционного проекта. По мнению авторов, в рамках использования второй группы обеспечения, можно получить объективную информацию о качестве и профессионализме менеджмента заемщика, об эффективности маркетинговых мероприятий, о вероятности своевременной реализации проекта и т.д. Следовательно, недостаточность предлагаемого заемщиком материального обеспечения инвестиционного кредита не должна быть бесспорным основанием для отказа в предоставлении такого кредита. Это определяет необходимость владения специалистов коммерческого банка методами анализа и оценки видов информационного обеспечения. Что, по мнению авторов, является объективным основанием для увеличения доли коммерческого банка в будущей выгоде от реализации инвестиционного проекта. 


\section{П.П. Князев, М.Н. Клименко, Д.В. Моторнюк}

С позиции коммерческого банка важной особенностью инвестиционного кредитования являются модели и технологии оценки рисков долгосрочного кредитования, а также методы их минимизации. В рамках организации риск-менеджмента коммерческим банкам необходимо иметь реальное представление о той системе рисков, которая связана с инвестиционным кредитованием в целом или с финансированием конкретного инвестиционного проекта. В настоящее время основным выступает вопрос о связанных непосредственно с работой заемщиков рисках для коммерческих банков. В этой связи, по мнению авторов, специалистам коммерческих банков необходимо иметь достоверное представление о реальных источниках риска невозврата заемщиком представленных ему кредитных средств на цели реализации инвестиционного проекта.

Рассмотрим систему факторов риска инвестиционного кредитования, объективно существующую в деятельности потенциального заемщика, представив ее в схематичном виде (рис. 11).

В рамках субъектной составляющей факторы риска можно разделить на две группы: внешние - независящие от заемщика и определяемые средой его функционирования, и внутренние - непосредственно связанные с осуществлением заемщиком деятельности.

Первой группой являются внешние факторы риска. Рассмотрим каждую подгруппу подробнее.

Риски, связанные с мерами государственного регулирования, находятся в следующих сферах: материально-техническое снабжение; охрана окружающей среды; проектные и иные нормативы; производственные нормативы; землепользование и использование природных ресурсов; экспорт и импорт; ценообразование; налогообложение. Данные риски имеют фактическое отображение в рамках законодательного поля и административного управления экономическими процессами в государстве. По мнению авторов, значимость этих факторов определяется возможностью прогнозирования адекватных и объективных нововведений со стороны государственных органов, которые могут повлечь задержку или невозможность осуществления инвестиционного проекта, как на стадии его разработки, так и на стадии реализации и непосредственного финансирования. 


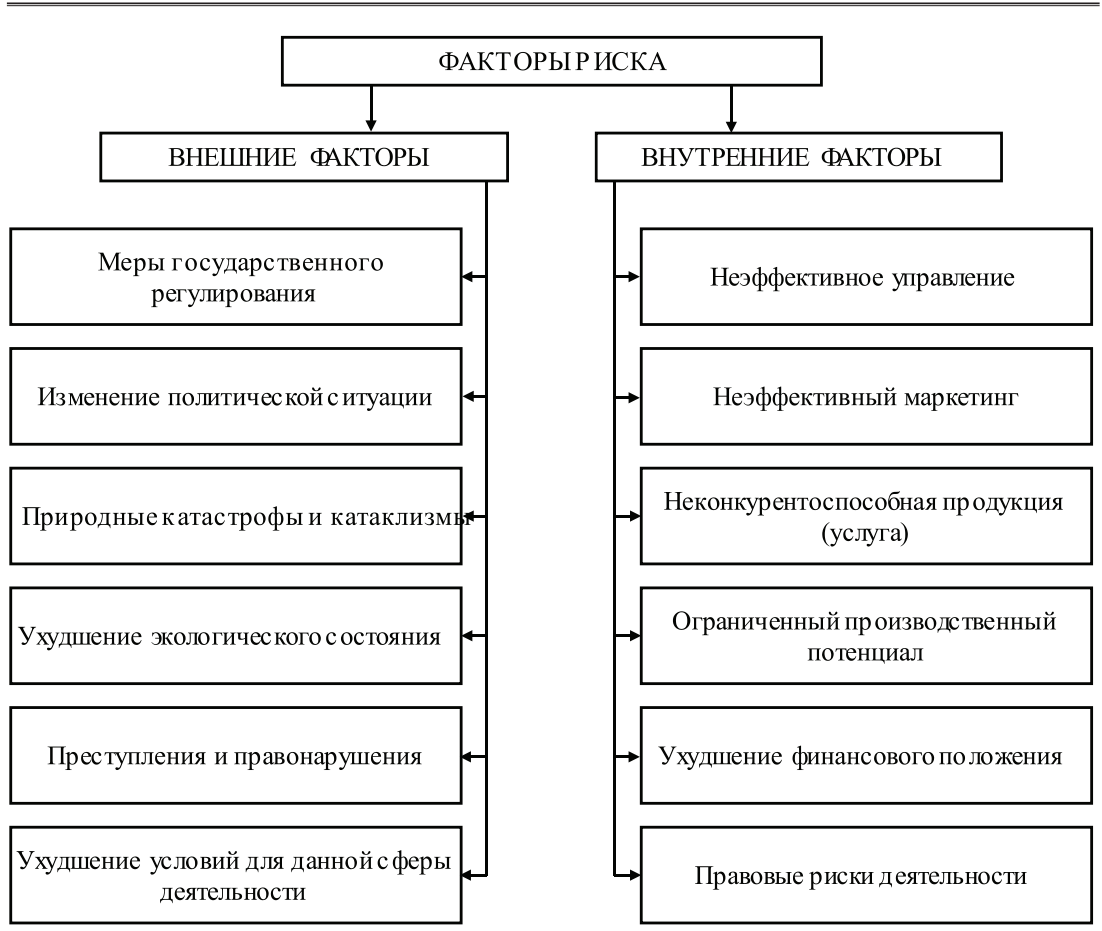

Рис. 11. Факторы риска при инвестиционном кредитовании

Не менее важным, с позиции возможного влияния на процесс инвестирования, является изменение политической ситуации. С позиции авторов, основными рисками данной подгруппы являются смена политической обстановки, которая в последствие повлечет значительные изменения в национальной экономике, а также изменения, повлекшие за собой политическую нестабильность и вызвав тем самым кризисные явления отраслевого или макроэкономического масштаба.

С практической позиции осуществления инвестиционного кредитования важными являются мероприятия по оценке факторов риска, относящихся к подгруппам природных катастроф и катаклизмов, а также ухудшения экологического состояния. По мнению авторов, речь идет об анализе существующей информации о потенциальной 


\section{П.П. Князев, М.Н. Клименко, Д.В. Моторнюк}

возможности наступления указанных событий. Что в свою очередь требует дополнительных разработок и исследований - следовательно расходов.

Рассматривая подгруппу факторов риска, связанных с преступлениями и правонарушениями, авторы считают целесообразным анализировать при реализации инвестиционных решений, как общую криминогенную обстановку на территории, так и возможность действий преступного характера со стороны заинтересованных субъектов, в том числе конкурентов.

Последняя подгруппа включает факторы риска, связанные с ухудшением условий для сферы деятельности заемщика, либо сферы будущего использования результатов инвестиционного решения. По мнению авторов, в рамках данной подгруппы основными представляются риски, определяющие значительную угрозу реализации инвестиционного проекта, инвесторов и кредиторов проекта, либо непосредственно заемщика. Подобными явлениями могут выступать: банкротство подрядчиков и контрагентов; повышение стоимости сырья или топливно-энергетических ресурсов; изменение требований потребителей, в том числе носящие иррациональный характер; изменение конкурентного взаимодействия (ослабление или усиление); неблагоприятная динамика макроэкономических показателей, которая в значительно степени будет иметь отрицательные последствия.

Эти факторы рисков не зависят от непосредственной деятельности хозяйствующего субъекта. Их также целесообразно принимать во внимание и учитывать в отношении любой группы аналогичных или однородных заемщиков, нарабатывая наиболее возможный объем оперативной информации.

Второй группой факторов являются внутренние, т. е. непосредственно связанные с деятельностью хозяйствующего субъекта. Рассмотрим каждую подгруппу.

В качестве первого внутреннего фактора риска, по мнению авторов, следует рассматривать неэффективное управление. Смысловое содержание выражается отсутствием или недостаточной квалификацией менеджмента хозяйствующего субъекта, осуществляющего текущее и стратегическое управление. В данном контексте под 
неэффективным управлением можно определить необъективное установление плановых показателей, а также не достижение результатов. При неэффективном управлении риски возникают вследствие неудовлетворительного состояния следующих подсистем и элементов системы управления: анализ состояния предприятия; состояние планирования; система контроля; распределение прав и ответственности в системе управления; использование современных методов и средств управления; квалификация руководителей и ведущих специалистов; качество организационно-управленческой документации. В современной практике неэффективным управлением можно также частично определять ситуации, когда топ-менеджерами хозяйствующего субъекта являются непосредственные владельцы бизнеса.

Следующим внутренним фактором является неэффективный маркетинг. Полное или периодичное отсутствие в хозяйствующем субъекте, планирующем к реализации инвестиционные решения (проекты), эффективного маркетинга в большинстве случаев создает проблемы, как с реализацией проекта, так и с возвратом средств, полученных на заемной основе. Если система маркетинга в хозяйствующем субъекте налажен и действует эффективно, то обязательно ведется работа по следующим направлениям: изучение всех групп потребителей; исследование мотивов поведения потребителя; анализ рынка предприятия; исследование продукта; анализ форм и каналов реализации; анализ объема товарооборота предприятия; изучение конкурентов; исследование рекламной деятельности; способы эффективного продвижения товара; изучение рыночного сектора и т.д. По мнению авторов, эффективная система маркетинга является основным катализатором потенциальной инвестиционной активности хозяйствующего субъекта.

Рассматривая группу внутренних факторов, следует также отметить, что неконкурентоспособная продукция является серьезным источником рисков ввиду возможного нарушения следующих элементов системы управления хозяйствующего субъекта: управление качеством; управление себестоимостью; разработка конкурентоспособной продукции; кооперация и сотрудничество; соблюдение стандартов и нормативов; стратегия обеспечения конкурентоспособности. 


\section{П.П. Князев, М.Н. Клименко, Д.В. Моторнюк}

В достаточной степени сложным является фактор ограниченного производственного потенциала. Подобная ситуация в хозяйствующем субъекте создает повышенные риски ввиду неудовлетворительного состояния следующих элементов: обеспеченность основными средствами; обеспеченность нематериальными активами; обеспеченность оборотными средствами; организация производства; организация труда. По мнению авторов, фактор ограниченности производственного потенциала является одним из основных сдерживающих момент расширения инвестиционной активности хозяйствующих субъектов.

В рамках отражения объективного состояния деятельности хозяйствующего субъекта важное место занимает фактор риска, связанный с финансовым положением. На данный фактор негативно влияют сбои в создании рационального финансового механизма, недоработки в финансовой политике и нарушения в оперативном управлении финансами.

Последним фактором являются правовые риски деятельности. Их источниками могут быть различные правоотношения, в том числе лицензии, патентное право, невыполнение контрактов, судебные процессы с внешними партнерами, внутренние судебные процессы, форс-мажорные обстоятельства. По мнению авторов, правовые ограничения активизации инвестиционной деятельности играют отрицательную роль при реализации проектов и расширении деятельности хозяйствующего субъекта.

Совокупность набора факторов внешнего и внутреннего характера, или влияние одного из них, может отрицательно повлиять как на ход реализации инвестиционных инициатив, так и поставить под вопрос возможность их осуществления в целом.

При проведении операций инвестиционного кредитования особое значение принимает риск-менеджмент, работающий в кредитной организации. Долгосрочные кредитные операции накладывают определенные расширенные требования к оценке и прогнозированию рисковых результатов. В этой связи, значительное место в деятельности коммерческих банков по реализации инвестиционных решений занимает управление техническим, коммерческим, экономическим 
и политическим рисками, которые могут оказать влияние на инвестиционный проект как на первой его фазе - в период строительства, так и на второй фазе - в период производства.

Наиболее актуальным для инвестиционного кредитования является риск незавершения строительства, т.е. прерывание реализации на инвестиционной фазе. Итогом возникновения этого риска определяются инциденты, которые могут нанести полный или частичный физический урон проекту, трудностями генерального подрядчика, изменениями в плане проектно-строительный работ, невозможностью завершения проекта из-за расхождений между планируемыми финансовыми показателями и фактическими, сложившимися к окончанию инвестиционной фазы и непосредственному началу производства в результате радикальных изменений в экономической обстановке.

При реализации инвестиционных инициатив определяющим фактором являются сметные возможности. Ограничение по объему инвестиционных ресурсов определяют важность учета и планирования риска увеличения инвестиционной стоимости. Риск перерасхода может наступить в связи с задержками, постоянным модифицированием проекта, недооценкой строительных затрат. По мнению авторов, целесообразным является планирование объема средств фондированных с целью финансирования непредвиденных расходов в случае сметного удорожания реализации инвестиционного проекта.

Инвестиционная фаза реализации считается завершенной только после выполнения определенных, ранее установленных критериев. В современной практике инвестирования с привлечением кредитных организаций окончание инвестиционной фазы определяется независимыми консультантами коммерческих банков. После непосредственного начала производственной фазы коммерческие банки, выступающие источниками инвестиционных ресурсов, могут столкнуться с производственным, рыночным, финансовым и политическим рисками. Рассмотрим каждый риск в отдельности.

Производственный риск может быть связан с техническими и технологическими проблемами (неадекватный дизайн проекта, слабости инженерного обеспечения и т.д.) или с экономическими проблемами (увеличение производственных затрат, сокращение 


\section{П.П. Князев, М.Н. Клименко, Д.В. Моторнюк}

поставок). В настоящее время целесообразно, по мнению авторов, чтобы данный риск был принят на себя частично кредитором частично заемщиком, в степени зависящей от масштабов инвестиционного проекта.

Рыночный риск может возникнуть из-за неправильной оценки рынка (общего размера, сегментация и деление на сектора), неконкурентности производимой продукции, снижения цен, ограничения возможностей продажи (например, аннулирование длительных контрактов о продаже). Этот риск может быть ограничен, но не ликвидирован полностью, при помощи разумной осторожности, при установлении цен, детального анализа контрактов о продаже и тщательного изучения рынка. В рамках реализации инвестиционных инициатив, по мнению авторов, основным ответственным за данный риск субъектом должен являться заемщик. Однако в связи с тем, что кредитор в большинстве случаев принимает решение о финансировании на основе информации, предоставленной инициатором проекта, эффективность планирования этого риска должна изучаться субъектом источником инвестиционных ресурсов.

Финансовый риск связан с возможным увеличением затрат на текущее финансирование инвестиционного проекта. Этот риск можно минимизировать путем заключения ограниченных договоров, лимитирующих вложений, дивидендов и заемных полисов. При осуществлении операций инвестиционного кредитования коммерческие банки рассчитывают на положительный денежный поток для погашения кредитных ресурсов. Решение об окончании реализации инвестиционного проекта может принести коммерческому банку убытки в виде недополучения процентного дохода и невозврата заемных средств. Поэтому, по мнению авторов, с правовой точки зрения сделка по кредитованию инвестиционных инициатив должна быть реализована таким образом, чтобы коммерческий банк имел возможность требовать продолжения деятельности до тех пор, пока инвестиционный проект способен приносить доход, достаточный для оплаты всего объема затрат, даже если инициатор проекта пожелает прекратить его в связи с низкой выгодой.

Существенное влияние на развитие инвестиционного кредитования может оказать политическая обстановка в стране. Заемщики стремятся 
к такой финансовой структуре, которая позволяет им сместить хотя бы часть политического риска иностранных проектов на коммерческие банки. Это перемещение риска является одним из факторов прогресса международного инвестиционного кредитования. В некоторых случаях заемщики, которые не обращаются к отечественному инвестиционному кредитованию, стремятся к международному инвестиционному кредитованию только для того, чтобы покрыть политический риск и готовы нести технический и коммерческий риски сами. Политический риск, от которого стремятся избавиться заемщики, может повлиять как на заемщика или заемные обязательства (экспроприация, национализация), так и на экономическую обстановку вокруг проекта и соответственно на его доходы (налоги, норма производства, вынужденная распродажа, навязанные цены, изменения в промышленных соглашениях).

Для минимизации рисков инвестиционного кредитования коммерческие банки должны следовать определенным базовым правилам, к числу которых относятся: тщательный анализ всевозможных аспектов инвестиционного проекта, в том числе с помощью независимых консультантов; в определенной степени пессимистичный подход к определению суммы капиталовложений, учитывающий потенциальные издержки; использование защитного коэффициента, определяющего сумму безоборотного займа, выплаты по которому обеспечиваются денежным потоком проекта; поиск общего интереса, связывающего заемщика и кредитора.

Таким образом, система рисков, связанных с деятельностью любого участника схемы инвестирования, как кредитора, так и заемщика, очень сложна и любой из ее элементов может стать причиной незавершения инвестиционных инициатив, невозврата кредитных ресурсов, не говоря уже о весьма возможном сочетании воздействия нескольких элементов (или факторов риска) одновременно. Отсюда, по мнению авторов, вытекает объективная необходимость тщательной проработки механизмов и инструментов, реализованных в кредитной политике банка, а также таких ее аспектов, как система анализа и планирования рисковых результатов в деятельности заемщиков, модифицирующая модель оценки возможности кредитования. 


\section{Гдава 2. ОПРЕДЕДЯЮЩИЕ НАПРАВ АЕНИЯ СОВЕРШЕНСТВОВАНИЯ МЕХАНИЗМА РЕАЯИЗАЦИИ ИНВЕСТИЦИОННОГО КРЕДИТОВАНИЯ}

\section{1. Адгоритм инвестиционно-кредитного администрирования в деятельности коммерческого банка}

В учебном пособии авторами изучена действующая технология проведения операций инвестиционного кредитования в российских коммерческих банках. В практике рассмотрения инвестиционных проектов и принятия решения о предоставлении кредитных ресурсов существуют моменты, не позволяющие активно развивать данные операции. Среди них сдерживающие расширение деятельности коммерческих банков ограниченность ресурсной базой, невыполнением нормативов Центрального банка Российской Федерации; нехватка квалифицированного персонала; открылись проблемы несовершенства внутренних бизнес-процессов.

В учебном пособии авторами предложены направления совершенствования инвестиционного кредитования, разработана методика инвестиционно-кредитного администрирования коммерческого банка.

Актуальность представляемых преобразований определяется следующим. Основным из принципиальных моментов, определяющих эволюцию каждого хозяйствующего субъекта, является необходимость постоянных качественных изменений внутренних бизнеспроцессов. Практика показывает, что как только останавливаются или уменьшаются темпы развития, одномоментно начинается потеря клиентских или конкурентных позиций.

Постоянные изменения стали одним из отличительных знаков рыночной экономики современного этапа развития цивилизационных процессов. Они затрагивают практически все области экономической жизни. В подобных рамках, по мнению авторов, первыми должны реагировать на данные преобразования финансовые институты, в частности, коммерческие банки. 
Непрерывно изменяющаяся внешняя среда обусловливает для коммерческих банков необходимость следовать всем новейшим тенденциям. С другой стороны, существует мнение о том, что в определенной степени необходимо придерживаться консервативной политики. С авторской позиции, подобное направление является ограниченно или частично оправданным. Консерватизм был обязателен во многих сферах деятельности, но в настоящей экономической ситуации он не отражает трансформаций и эволюционных изменений экономических процессов. Это иллюстрируется на примере таких, как считалось ранее, консервативных сфер бизнеса, как банковское дело. Сегодня эта сфера финансового бизнеса отвергает большинство из традиционных подходов и активно меняет практику своей работы, постоянно внедряя новые подходы и технологии. По мнению авторов, это связано, прежде всего с тем, что, не отслеживая тенденций рынка, запросов потребителей и новейших технологических достижений, коммерческому банку невозможно удержать рыночные позиции.

Определяющей причиной совершенствования становятся глобальные изменения в научно-технической и технологических сферах. Именно они принципиально изменили экономическое пространство, создав ситуацию, при которой потенциальное предложение на большинстве рынков, в том числе банковском, существенно превышает спрос.

Следующая важная причина, активизирующая коммерческие банки на постоянные изменения, конкурентная борьба. Финансовые рынки стали прозрачны и открыты. В этой связи, на информационном банковском рынке все действия заметны и предсказуемы. В подобной ситуации достаточно менеджменту коммерческого банка реализовать неправильные управленческие решения или понизить качество предлагаемых услуг, кредитная организация сразу начинает терять клиентскую базу. В то же время, авторы отмечают, что даже высокоразвитому банку необходимо совершенствоваться, так как все положительное в его работе и технологиях достаточно быстро становится известным на рынке и активно внедряется конкурентами. Поэтому, чтобы находиться в активной позиции, необходимо постоянное изменение внутренних бизнес-процессов. 


\section{П.П. Князев, М.Н. Клименко, Д.В. Моторнюк}

На протяжении последних нескольких десятилетий в финансовой сфере развитых стран менялось представление о целях деятельности коммерческих банков. Первоначально основной целью деятельности кредитной организаций понималась прибыль. В ситуации развития и увеличения объемов рынка финансовых продуктов приоритеты в банковском менеджменте сменились, и основной целью была провозглашена доля рынка. Коммерческие банки полагали, что высокие прибыли уже не могут обеспечить им стабильности и их главной стратегической целью должно быть расширение рыночной доли. Но и эта концепция сменилась новой. В современной ситуации ведущие экономисты и ученые провозгласили основной целью достижение качества банковского продукта, предоставляемого клиенту. Если кредитная организация в состоянии обеспечить высокое качество услуг, то увеличится прибыль и расширится доля на рынке.

По мнению авторов, помимо внешних существуют и внутренние причины, создающие необходимость постоянных изменений бизнес-процессов. Если коммерческий банк в момент своего основания был построен по самой оптимальной схеме, то через некоторое время утрачивает исходную оптимальность, приобретает функциональную и тактическую несогласованность во внутренних бизнес-процессах.

Появление негативных моментов связано с особенностями организации деятельности каждого конкретного коммерческого банка. Как правило, они кроются в несовершенстве действующих технологий и механизмов ведения деятельности кредитной организации и принятии управленческих решений. Все это приводит к деформации базисных принципов и ориентиров развития коммерческого банка.

В деятельности зарубежных коммерческих банков решение этой проблемы является одним из первостепенных направлений повышения качества услуг и достижения целевых итоговых показателей. Считается, что кредитная организация не реже какого-либо определенного периода в зависимости от своих размеров и особенностей должна производить на основе детального анализа текущей ситуации полный или частичный реинжиниринг своей деятельности. Программа таких изменений включает различные направления преобразований: реструктуризация; построение новой концепции 
взаимоотношений, мотивации и менеджмента; смена части специалистов; стратегическая переориентация; модернизация технологической и информационной базы; реинжиниринг основных и вспомогательных бизнес-процессов, системы управления в соответствии со стратегическими целями и т. п.

Это, по мнению авторов, объясняет необходимость постоянных изменений, актуальность которых в российских условиях еще выше, так как в отличие от зарубежных стран кардинальные изменения в национальной экономике происходят более стремительными темпами.

Одним из важнейших направлений расширения и совершенствования деятельности коммерческого банка является инвестиционное кредитование. В зависимости от масштабов деятельности и специфических аспектов осуществления отдельных операций в каждом коммерческом банке действует конкретный порядок предоставления инвестиционных кредитов. В определенных случаях меняется лингвистическая составляющая, однако экономический смысл остается единым. Основное отрицательное воздействие оказывают проблемы первого уровня, а точнее - внутренние бизнес-процессы, т.е. те методики, технологии и инструментарий, используемые для анализа инициатив и принятия инвестиционных решений. Проблемы, ограничивающие развитие данных операций банковского кредитования, такие как нехватка ресурсов, специалистов и технической базы, являются трудностями второго порядка.

Авторами предлагается методика администрирования инвестиционного кредитования, адаптируемая к деятельности кредитной организации, независимо от масштабов проводимых операций. Методика разработана на основе теоретических и практических аспектов, учитывающих специфику и адекватную поэтапность операций инвестиционного кредитования. Ее применение позволит кредитующему подразделению коммерческого банка значительно повысить объемы и эффективность предоставления инвестиционных кредитов, уменьшить временной параметр при рассмотрении инвестиционных инициатив.

В соответствии с данной методикой для коммерческого банка инвестиционным считается проект, предусматривающий привлечение денежных средств в создание нового предприятия/производства 


\section{П.П. Князев, М.Н. Клименко, Д.В. Моторнюк}

(или объекта) или расширение, реконструкцию, модернизацию, капитальный ремонт или иное изменение объекта с целью получения выручки при коммерческой эксплуатации предприятия/производства (или объекта), из которой покрываются расходы по обслуживанию привлеченных кредитных ресурсов и возврату основного долга.

Через инвестиционное кредитование рассматривается участие коммерческого банка в инвестиционном проекте в форме предоставления кредита на срок более одного года, при котором источником возврата кредита является вся хозяйственная и финансовая деятельность заемщика, включая доходы, генерируемые инвестиционным проектом непосредственно.

Первоначально представим состав комиссионных платежей. При кредитовании инвестиционных проектов коммерческие банки взимают с заемщика в зависимости от видов, характера и сложности, выполняемых операций различные комиссионные платежи. В частности, плата за открытие кредитной линии, ссудного счета, пользование лимитом кредитной линии, резервирование ресурсов, управление, организацию финансирования и экспертизу проекта, неполное исполнение условий кредитного договора в части требований, предъявляемых к его обеспечению.

Возможно взимание и других платежей за услуги коммерческого банка, предусмотренных внутренними нормативными документами, например, сборником тарифов на оказание услуг и проведение операций. В зависимости от особенностей различных видов кредитования и проведения отдельных операций, заемщиком могут производиться и другие платежи за обслуживание кредита (плата за структурирование сделки и обеспечения, плата за изменение условий типовой кредитной документации, плата за проверку залога с выездом на место его расположения и т.д.).

В связи с тем, что инвестиционные кредиты в большинстве случаев предоставляются на длительный срок, существует специфика взимания процентных платежей за пользованием кредитными ресурсами.

Уплата процентов за пользование кредитом производится ежемесячно или ежеквартально. Размер процентной ставки по кредиту может быть дифференцирован и меняться в зависимости от ежемесячных (ежеквартальных) кредитовых оборотов по счетам заемщика, открытым в коммерческом банке. 
Этап І. Получение заявки на предоставление кредитных ресурсов. Экспресс анализ.

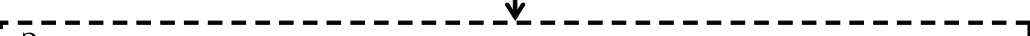
Заполнение потенциальным заемщиком дополнительных документов по инвестиционному проекту.

\section{Этап II.}

Предварительная оценка эффективности инвестиционного проекта. i - - I инвестиционного проекта.

Этап III. Проведение финансового анализа текущей деятельности потенциального заемщика.

Этап IV. Анализ основных параметров инвестиционного проекта.

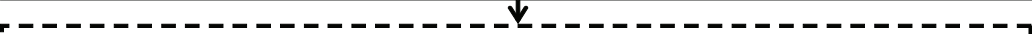
I Получение информации о текущей стадии реализации инвестиционного

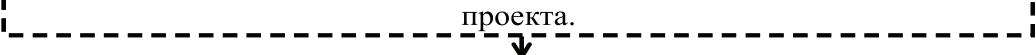

Этап V. Анализ условий сделок по инвестиционному проекту.

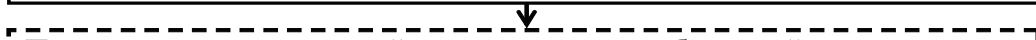
П Получение разрешительной документации, необходимой для реализации I_-_- - - - - - - - - инвестиционного проекта.

Этап VI. Анализ финансовых параметров инвестиционного проекта. Оценка рисков.

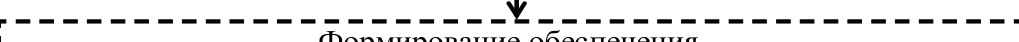
Формирование обеспечения.
Получение информации от специализированных подразделений.

Этап VII. Рассмотрение вопроса о кредитовании коллегиальным органом коммерческого банка.

r- - - - - - - - - - - - - - - - - - - - - - - - - - -

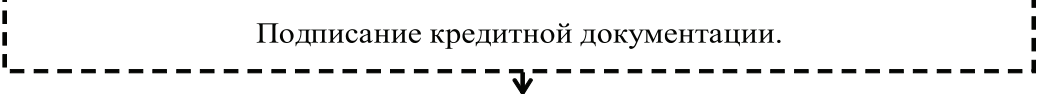

Этап VIII. Предоставление кредитных ресурсов.

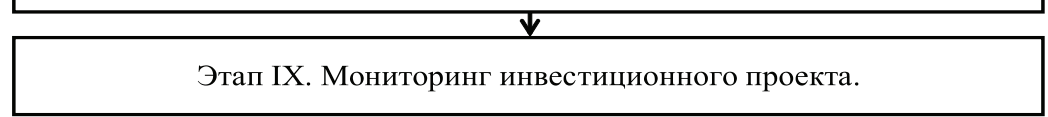

Рис. 12. Методика инвестиционно-кредитного администрирования 


\section{П.П. Князев, М.Н. Клименко, Д.В. Моторнюк}

В целях поддержания конкурентоспособного уровня процентных ставок по долгосрочным кредитам, предоставляемым на цели кредитования инвестиционных проектов, возможно снижение процентной ставки до величины не ниже минимального уровня процентных ставок, по мере сокращения срока, оставшегося до даты последнего платежа в погашение кредита.

При этом использование указанного механизма может быть увязано с моментом окончания инвестиционной фазы проекта, финансируемого коммерческим банком или с моментом достижения заемщиком определенных, сформулированных в кредитной документации параметров по инвестиционному проекту, которые свидетельствуют о существенном снижении риска непогашения кредита.

На первом этапе при обращении в коммерческий банк инициатор проекта (потенциальный заемщик) направляет заявку на предоставление инвестиционного кредита, в которой указывается цель, сумма, сроки кредитования и возможное обеспечение.

Заявка на кредитование направляется для предварительной оценки в кредитующее подразделение коммерческого банка. В течение непродолжительного периода, обычно в течение 2 рабочих дней с момента получения заявки, специалист банка направляет инициатору проекта (потенциальному заемщику) для заполнения специальные документы:

- схематичный бизнес-план инвестиционного проекта, который содержит в краткой форме информацию об инициаторе проекта и о содержании самого проекта, с указанием основных параметров;

- информационные формы, содержащие числовые показатели предполагаемого к реализации инвестиционного проекта.

В рамках второго этапа на основании полученных данных и существенных стоимостных параметрах, используя применяемые в коммерческом банке технологии, выполняется предварительная оценка коммерческой эффективности инвестиционного проекта и анализ финансового состояния потенциального заемщика.

По результатам предварительной оценки коммерческой эффективности проекта и финансового состояния клиента, переговоров с инициатором инвестиционного проекта (потенциальным заемщиком), анализа наличия или отсутствия определенных факторов, при существовании которых участие банка в финансировании проекта является высокорискованным, готовится предложение 
о целесообразности продолжения работы над проектом и форме кредитования. Выделим две группы факторов отклонения положительных предложений. Первая группа универсальна и действует как для инвестиционного кредитования, так и для проектного финансирования. Вторая группа стоп-факторов накладывает дополнительные, более жёсткие требования к характеристикам инвестиционного проекта и применяется при проектном финансировании (рис. 13,14).

В рамках третьего этапа на основе рассмотрения финансовой отчетности выполняется финансовый анализ потенциального заемщика за определенный период времени (как правило, за 3-5 лет).

Далее на четвертом этапе рассмотрим производственный цикл инвестиционного проекта. Проводится анализ маркетингового исследования рынка, обоснования конкурентоспособности предполагаемой к выпуску продукции (услуг) и будущей сбытовой стратегии потенциального заемщика.

Дополнительно определим, в какой фазе реализации находится инвестиционный проект в настоящее время, насколько активно идет его осуществление, изучаются документы, которые на данной фазе проекта должны быть оформлены. На основе рыночной конъюнктуры, опыта и деловой репутации проверяется правильность выбора партнеров-исполнителей. Рекомендуется при крупномасштабных проектах, стоимость которых превышает 10 млн долл. США, выбор партнеров осуществлять по результатам тендера.

На пятом этапе специалисты коммерческого банка анализируют условия сделок по инвестиционному проекту (контрактов/договоров или проектов этих документов) в целях снижения уровня проектных рисков, распределения их между участниками проекта и исключения неприемлемых для кредитной организации условий.

В дальнейшем проверяется получение потенциальным заемщиком разрешительной документации, необходимой для реализации инвестиционного проекта. Форма и состав разрешительной документации должны соответствовать действующему федеральному и региональному законодательству, отраслевым и иным стандартам, нормам и правилам. При большом объеме нормативных документов, определяющих требования к разрешительной документации, анализ разрешительной документации по проекту может проводиться с участием специалистов 
юридической службы коммерческого банка. Для крупномасштабных инвестиционных проектов могут привлекаться сторонние консультационные организации и органы государственного надзора.

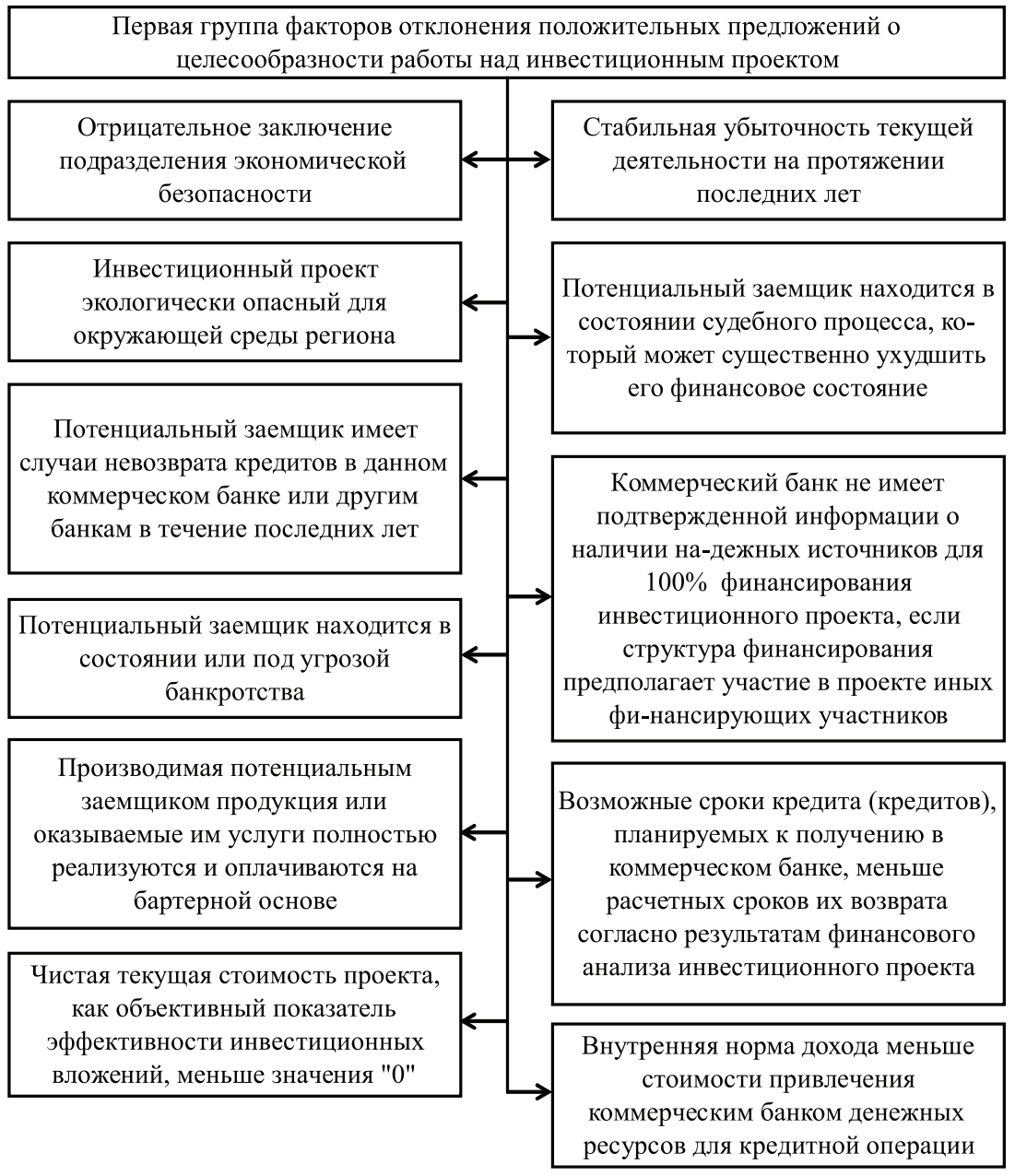

Рис. 13. Первая группа факторов отклонения положительных предложений о целесообразности работы над инвестиционным проектом 
Вторая группа факторов отклонения положительных предложений о целесообразности работы над инвестиционным проектом

Инвестиционный проект находится в регионе повышенной нестабильности

$$
\begin{gathered}
\text { Ограниченность прогнозируемого } \\
\text { сбыта продукции, генерируемой } \\
\text { инвестиционным проектом }
\end{gathered}
$$

Отсутствие адекватной условиям и сложности реализации инвестиционного проекта управленческой команды менеджеров
Отсутствие собственных средств заемщика или других участников проекта в структуре финансирования инвестиционного проекта

Рис. 14. Вторая группа факторов отклонения положительных предложений о целесообразности работы над инвестиционным проектом

В рамках шестого этапа на основе полученных числовых данных и после уточнения условий финансирования всеми участниками инвестиционного проекта, платежных условий всех контрактов, потребностей в оборотном капитале, затрат и поступлений по проекту в обязательном порядке проводится финансовый анализ проекта.

После изучения технико-экономических параметров инвестиционного проекта проводится анализ рисков. При анализе должны быть выявлены специфические и наиболее серьезные риски проекта (финансовые, технические, маркетинговые, проектные, производственные, политические, и т.д.), учтено распределение рисков между участниками проекта, предложены необходимые меры для снижения кредитного риска коммерческого банка.

В данном случае кредитный риск коммерческого банка предполагает вероятность того, что банк понесёт финансовые потери вследствие кредитования инвестиционного проекта. Вероятность зависит от специфических проектных рисков и рисков, сопутствующих текущей деятельности заемщика. Эти риски обусловлены наступлением в ходе реализации инвестиционного проекта неблагоприятных ситуаций, следствием которых будет являться невыполнение заёмщиком 


\section{П.П. Князев, М.Н. Клименко, Д.В. Моторнюк}

своих обязательств перед банком или необходимость дополнительных расходов, что в свою очередь снизит инвестиционную рентабельность вложений кредитных ресурсов.

Для принятия решения о кредитовании инвестиционного проекта коммерческому банку необходимо выявить наиболее типичные для данного проекта риски, оценить размер риска (величину вероятности), рассмотреть последствия наступления неблагоприятной ситуации для реализации проекта в целях оптимального хода обслуживания задолженности перед кредитной организацией. Целесообразно осуществление мер по минимизации рассматриваемых рисков, с предварительной оценкой необходимых масштабов мероприятий по ограничению рисков. По результатам комплексной оценки рисков, с учётом мер по минимизации рисков, необходимо сделать выводы о том, насколько уровень рисков по инвестиционному проекту приемлем для коммерческого банка, выводы о требуемом уровне обеспечения по кредиту (гарантии) и других условиях кредитования проекта или определить условия, при выполнении которых проект может быть принят к кредитованию.

Для целей практического анализа авторами предлагается классификация рисков на количественные (оценка которых возможна методами количественного анализа) и качественные (влияние которых на показатели проекта трудно выразить численными величинами), внутренние по отношению к участникам проекта и внешние, риски на инвестиционной и на производственной фазе проекта, страхуемые (покрываемые за счёт гарантий, страхования, резервов и пр.) и не страхуемые. В большинстве случаев следует использовать строго систематизированную классификацию рисков, основанную на источнике их возникновения (с чем связан риск), так называемый перечень наиболее типичных рисков инвестиционной деятельности с точки зрения кредитующего коммерческого банка.

Авторами в приложении 1 представлен набор рисков, включенный в методику администрирования, при инвестиционном кредитовании и меры по их минимизации.

Кредитующее подразделение коммерческого банка должно максимально использовать численные методы оценки влияния риска на экономические показатели инвестиционного проекта. 
По мере разработки структуры финансирования, коммерческой схемы реализации и анализа рисков инвестиционного проекта формируется обеспечение своевременного и полного исполнения обязательств заемщика по кредиту коммерческого банка. При этом возможные варианты обеспечения должны оцениваться с точки зрения:

- наличия прав заемщика и/или третьего лица на предлагаемое обеспечение;

- потенциальной ликвидности этого обеспечения;

- возможности его использования в качестве основного, дополнительного или вспомогательного обеспечения.

Обеспечение, которое имеет величину и ликвидность, достаточную для покрытия всей суммы основного долга и процентов (или значительной части суммы) фиксируется как основное. На него в первую очередь будет обращаться взыскание в случае нарушения заемщиком своих обязательств перед коммерческим банком.

Исходя из значимости и целесообразности, основанных на практических аспектах, в качестве основного обеспечения могут быть представлены:

1) залог недвижимости (производственной и непроизводственной);

2) залог оборудования, транспортных средств, другого имущества;

3) банковские гарантии;

4) поручительства платежеспособных предприятий и организаций;

5) залог имущественных прав на недвижимость (в том числе земли);

6) залог прав по инвестиционным контрактам, прав на объекты незавершенного строительства;

7) средства на депозитном счете заемщика или его учредителей в коммерческом банке;

8) залог ценных бумаг (государственные, корпоративных эмитентов, собственных обязательств кредитной организации);

9) поручительства Министерства финансов Российской Федерации или органов исполнительной власти субъектов Российской Федерации.

Если необходимо увеличить общую сумму обеспечения, то помимо основного заемщик предоставляет дополнительное обеспечение. В качестве последнего может использоваться любое из вышеперечисленных видов обеспечения, но его ликвидность, как правило, ниже 


\section{П.П. Князев, М.Н. Клименко, Д.В. Моторнюк}

основного обеспечения и взыскание на дополнительное обеспечение обращается только в случае нехватки основного обеспечения для погашения задолженности.

Перед переходом к следующему этапу рассмотрения инвестиционного проекта осуществляется получение информации о заемщике и других участниках проекта от подразделения экономической безопасности коммерческого банка. Заключение данного подразделения должно содержать выводы о деловой репутации заемщика и других участниках инвестиционного проекта, их руководителей, а также информацию об отсутствии факторов, при наличии которых участие кредитной организации в кредитовании проекта является высокорискованным.

На основе предложений потенциального заемщика анализируется структура финансирования инвестиционного проекта. Структура должна отражать все источники инвестиционных ресурсов, условия и формы финансирования проекта.

На седьмом этапе после того, как определены условия кредитования инвестиционного проекта коммерческим банком и достигнута ясность по вложениям средств остальных финансирующих участников проекта, формируется окончательный вариант структуры финансирования, и после анализа всей необходимой информации и заключения ответственных служб коммерческого банка, вопрос об участии кредитной организации в кредитовании инвестиционного проекта выносится на коллегиальный орган, в ответственность которого входит рассмотрение и принятие решений о предоставлении инвестиционных кредитов. В соответствии с положительным решением данного органа и на основе типовых форм готовится кредитный договор и иная кредитная документация.

В кредитном договоре в обязательном порядке указываются предварительные условия предоставления инвестиционного кредита (оформление залогов, гарантий, поручительств, финансируемых договоров или контрактов, открытие аккредитивов при финансировании экспортных проектов и другие условия предоставления кредита, указанные в решении кредитного комитета и до выполнения которых перечисление денежных средств по кредиту не допускается). 
Затем осуществляется открытие ссудного счета. Для проведения операций по выдаче кредита проверяется правильность оформления предоставленных заемщиком платежных документов и приложений к ним, необходимых для осуществления операций по счетам в соответствии с целевым назначением кредита.

При осуществлении операций инвестиционного кредитования чрезвычайно важной является процедура кредитного мониторинга. Кредитный мониторинг включает контроль целевого использования кредита, графика реализации проекта и структуры его финансирования. Данная процедура должна проводиться только в период предоставления кредитных ресурсов.

На основании рассмотренной методики инвестиционно-кредитного администрирования должно осуществляется инвестиционное кредитование на современном этапе развития банковских технологий. Специфика инвестиционного кредитования закладывается в деятельность конкретного кредитного института и осуществление реального инвестиционного проекта.

Предложенная авторами методика инвестиционно-кредитного администрирования позволяет усовершенствовать деятельность коммерческого банка при осуществлении операций инвестиционного кредитования.

Выделим положительные моменты внедрения методики инвестиционно-кредитного администрирования в деятельности кредитной организации.

Инвестиционно-кредитное администрирование, в форме структурированной методики, четко регламентирует сроки и ответственность в рамках функционирования внутреннего бизнес-процесса при кредитовании инвестиционного проекта. Поэтапное моделирование исключает возможность появления непроанализированных рисковых событий, способных нанести финансовый урон коммерческому банку или инвестиционному проекту. Основное содержание строится на последовательном анализе возможных рисков участия коммерческого банка в кредитовании инвестиционного проекта, это позволяет осуществлять мероприятия и предложения по хеджированию потенциальных рисков до принятия решения о начале рассмотрения 


\section{П.П. Князев, М.Н. Клименко, Д.В. Моторнюк}

и анализа инвестиционной инициативы. При рациональном использовании данной методики инвестиционно-кредитного администрирования уменьшится временной период, необходимый для принятия коммерческим банком решения об участии в кредитовании или отказе от предоставления кредитных ресурсов по инвестиционному проекту.

Заключительным этапом представляемой авторами методики инвестиционно-кредитного администрирования является проведение мониторинга инвестиционного проекта на этапе инвестиционной фазы до момента полного погашения задолженности по кредиту перед коммерческим банком.

\section{2. Методика инвестиционно-кредитной экспертизы с применением стандарт-факторного анадиза и модели адаптивных показателей}

Авторами на основе теоретических и практических аспектов разработана система мониторинга инвестиционного проекта, применимая в кредитной организации. Система оценки и получения адекватных выводов о течении инвестиционного проекта позволяет своевременно проводить соответствующие мероприятия для предотвращения отрицательных ситуаций, как для коммерческого банка, так и для участников и инициаторов проекта.

В рамках схематичного подхода система мониторинга выглядит следующим образом (приложение 2):

1. Изменения в структуре акционерного капитала компании-заемщика (сделки свыше $2 \%$ от уставного капитала).

2. Изменения в составе руководящего персонала предприятия и персонала, ответственного за реализацию инвестиционного проекта.

3. Основные условия инвестиционного кредитования (заключенные кредитные договоры в рамках инвестиционного проекта).

4. Структура финансирования с учетом целевого использования (в соответствии с графиком платежей по контрактам).

5. Освоение капитальных вложений (по справкам о темпах выполнения работ на основании процентовок).

6. Анализ финансово-хозяйственной деятельности предприятия и показателей инвестиционного проекта. 
7. Обеспечение по предоставленным кредитным ресурсам.

8. Изменения в отрасли, в которой осуществляется инвестиционный проект.

9. Основные выводы о дальнейшем сотрудничестве и взаимодействии коммерческого банка и заемщика.

В преамбуле к форме мониторинга инвестиционного проекта указываются следующие данные в табличной форме:

- Наименование инвестиционного проекта.

- Контрольная дата мониторинга (указывается дата, по состоянию на которую проводится мониторинг).

- Суть инвестиционного проекта (описывается цель, с которой реализуется проект, основные составляющие).

Первым разделом формы мониторинга описываются изменения или их отсутствие в структуре акционерного капитала компании-заемщика, проектной компании или инициатора инвестиционного проекта. В табличной виде приводится информация о сделках свыше $2 \%$ от уставного капитала вышеназванных хозяйствующих субъектов. Числовой порог получен из практических источников на основе анализа стартовой величины движения пакета имущественных ценных бумаг, которая может давать повод о прогнозировании возможной смены собственников, в т. ч. путем недружественного поглощения или слияния.

Информация формулируется и структурируется относительно следующих параметров: наименование акционера, уступившего или приобретшего долю в уставном капитале; перешедшая доля уставного капитала; дата перехода права собственности; чьи интересы представляет покупатель доли уставного капитала (в случае, если покупателем выступает финансовый агент).

Второй раздел отражает изменения в составе руководящего персонала компании-заемщика, проектной компании или инициатора инвестиционного проекта и персонала, ответственного за реализацию проекта. Изменения в составе топ-менеджмента со стороны заемщика может повлиять на взаимоотношения с коммерческим банком. В большинстве случаев, когда происходят подобные изменения, сотрудничество с кредитной организацией завершается погашением 


\section{П.П. Князев, М.Н. Клименко, Д.В. Моторнюк}

задолженности по инвестиционному кредиту или процедурой банкротства. Однако, возможны случаи, когда руководящий состав меняется в стратегических целях. Но подобные изменения должны быть проведены до реализации инвестиционных инициатив. Важным моментом является изменение в составе персонала, ответственного за реализацию инвестиционного проекта в рамках выполнения строительно-монтажных и специализированных работ, научных исследований и внедрения новейших технологий.

В третьем разделе описываются основные условия инвестиционного кредитования, в рамках всех заключенных кредитных договоров для финансирования данного инвестиционного проекта. Указывается вид кредитной документации (кредитный договор, договор об открытии кредитной линии, генеральное рамочное соглашение и др.), даты заключения и окончания действия кредитной документации, лимит кредитной задолженности, процентная ставка за пользование кредитными ресурсами, остаток по основному долгу на дату проведения мониторинга, а также целевое использование кредитных ресурсов в разрезе всей кредитной документации. Информация структурированная подобным образом позволяет увидеть комплексную картину задолженности перед коммерческим банком.

В четвертом разделе формы мониторинга инвестиционного проекта анализируется структура финансирования с учетом целевого использования (в соответствии с графиком платежей по контрактам). В рамках отчетных периодов (обычно ежеквартально) структурируется информация о финансировании расходов по реализации инвестиционного проекта из кредитных (заемных и собственных источников) в разрезе статей - оборудование, строительно-монтажные работы, проектные действия и прочие. Дополнительно структура финансирования с учетом целевого использования таблично расписывается по каждому конкретному кредитному договору с указанием следующей информации: наименование поставщика, подрядчика, агента; перечень поставляемого оборудования, комплектующих, материалов, выполняемых работ и т.д.; номер, дата и сумма по контракту (договору); срок поставки, выполнения работ, предоставления услуг; документы, подтверждающие целевое использование кредитных 
ресурсов (счета за выполненные работы, авансовые счета, накладные, акты выполненных работ, акты приемки в эксплуатацию и пр.); данные платежных поручений коммерческого банка (номер, дата, сумма):

а) с ссудного счета на расчетный счет;

б) с расчетного счета по целевому использованию.

В случае каких-либо отклонений в форме мониторинга инвестиционного проекта необходимо указать и проанализировать причины данных изменений.

Пятый раздел формы мониторинга описывает освоение общих капитальных вложений (по справкам о темпах выполнения работ на основании процентовок) без учета источника средств. Структурирование проводится по следующим параметрам: этапы выполнения работ (проектная часть, строительно-монтажные работы, поставка и монтаж оборудования, ввод в эксплуатацию); плановая дата начала и окончания работ; плановое выполнение в процентном отношении; фактическое выполнение в процентном отношении; фактическое отклонение в процентном отношении.

В данном разделе в случае наличия любых отклонений описываются причины их повлекшие, а также фиксируется информация о проведенных выездах специалистов коммерческого банка на место реализации инвестиционного проекта, с указанием визуальных выводов.

В шестом разделе проводится анализ финансово-хозяйственной деятельности компании-заемщика, проектной компании или инициатора инвестиционного проекта и показателей инвестиционного проекта. Информация структурируется по следующим пунктам:

1. Финансовые показатели деятельности: выручка от реализации; себестоимость реализованной продукции; прибыль (убыток) от реализации; операционное сальдо (проценты; прочие); внереализационное сальдо; прибыль (убыток) до налогообложения; налоги, выплачиваемые из прибыли, и другие обязательные платежи; прибыль (убыток) после налогообложения.

2. Структура активной и пассивной частей баланса: внеоборотные активы, в т.ч. основные средства, незавершенное строительство, долгосрочные финансовые вложения; оборотные активы, в т. ч. запасы, НДС, дебиторская задолженность, краткосрочные финансовые 


\section{П.П. Князев, М.Н. Клименко, Д.В. Моторнюк}

вложения, денежные средства, прочие оборотные активы; капитал и резервы, в т.ч. уставный капитал, добавочный капитал, резервный капитал, нераспределенная прибыль отчетного года; долгосрочные пассивы - кредиты и займы со сроком погашения более 12 месяцев; краткосрочные пассивы - кредиты и займы со сроком погашения менее 12 месяцев, кредиторская задолженность, прочие краткосрочные пассивы; валюта баланса.

3. Коэффициенты ликвидности и рентабельности.

4. Класс кредитоспособности.

5. Показатели инвестиционного проекта: выручка от реализации по каждой отдельной товарной группе; выручка от реализации, всего; прибыль от реализации; чистая прибыль.

6. Объемы реализации продукции (в натуральном выражении) по товарным группам.

7. Действующие на дату проведения мониторинга кредитные договоры, договоры лизинга: инвестиционные кредиты; кредиты на пополнение оборотных средств; лизинговые соглашения.

В шестом разделе формы мониторинга инвестиционного проекта указывается информация о заложенных активах, переданных в обеспечение по предоставленным коммерческим банком кредитным ресурсам. Структурирование построено на основе каждого конкретного договора залога, с указанием номера, даты, стоимости заложенного имущества, даты последнего осмотра и вывода о состоянии на дату проведения мониторинга. По итогам анализа делаются выводы о необходимости переоценки, замены предмета залога, продлении страхования и т.д.

Седьмой раздел консолидирует информацию об изменениях в отрасли, в которой осуществляется инвестиционный проект, по параметрам - отсутствуют, незначительные, существенные, применяемым к следующим аспектам: общие изменения в отрасли, носящие конъюнктурный характер; изменения в составе и ротации потребителей; по основным поставщикам сырья или сопутствующих услуг; по непосредственным конкурентам; доли рынка компании-заемщика, проектной компании или инициатора инвестиционного проекта. 
Последний раздел консолидирует основные выводы о дальнейшем сотрудничестве и взаимодействии коммерческого банка и заемщика по следующим составляющим: изменения в структуре акционерного капитала: отсутствуют, незначительные, существенные; в составе руководящего персонала: отсутствуют, незначительные, существенные; случаи не целевого использования кредита: отсутствуют, присутствуют; график выборки кредита: соблюдается, нарушается; график платежей по контрактам: соблюдается, нарушается; график освоения капитальных вложений: соблюдается, нарушается; оценка финансового состояния (коэффициенты ликвидности): ухудшилось, в норме, улучшилось; структура баланса предприятия: ухудшилась, в норме, улучшилась; показатели финансово-хозяйственной деятельности (план/факт): выполняется, не выполняется; показатели производственной деятельности (в натуральном выражении) (план/факт): выполняется, не выполняется; задолженность по займам, кредитам, лизингу: после начала финансирования проекта рост/снижение до $50 \%$, от 51 до $100 \%$, свыше $100 \%$; состояние обеспечения: удовлетворительное, хорошее, отличное; изменения в отрасли: отсутствуют, незначительные, существенные; наличие полного пакета документов по инвестиционному проекту: в наличии, не в наличии.

На основе полученных выводов формируется итоговое заключение, содержащее предложения по дальнейшему сотрудничеству на прежнем статусе взаимодействия, а также в необходимости по изменению условий кредитования, повлекшее за собой пересчет финансовой модели инвестиционного проекта в случае значительных отклонений от плановых показателей и существенного влияния произошедших изменений на перспективы реализации проекта, необходимый для минимизации или исключения возможности наступления кредитного риска для коммерческого банка.

Авторами в учебном пособии разработана процедура инвестиционно-кредитной экспертизы инвестиционного проекта, кредитуемого коммерческим банком. Необходимость проведения экспертизы определяется трудоемкостью и значительными затратами времени на проведение полного мониторинга с использованием выше предложенной авторами системы. 


\section{П.П. Князев, М.Н. Клименко, Д.В. Моторнюк}

В целях повышения эффективности и объективного сокращения действий специалистов кредитующего подразделения коммерческого банка следует ранжировать кредитуемые инвестиционные проекты по степени необходимости проведения полного мониторинга.

Целью инвестиционно-кредитной экспертизы инвестиционного проекта является оценка возможности неисполнения кредитных обязательств со стороны заемщика или наступления отрицательных параметров реализации проекта.

В рамках экспертной модели определяется три объектных уровня экспертизы, к которым может относиться компания-заемщик, проектная компания или инициатор инвестиционного проекта.

Представим первый объектный уровень экспертизы. Подразумевается, что компания-заемщик, проектная компания или инициатор инвестиционного проекта, со стороны которой не ожидается неисполнения обязательств. Подверженность воздействию неблагоприятных перемен в финансовых и экономических условиях реализации инвестиционного проекта незначительна. Денежный поток, генерируемый инвестиционным проектом, имеет устойчивую тенденцию роста. Возможность неисполнения кредитных обязательств со стороны заемщика или наступления отрицательных параметров реализации проекта оценивается как маловероятная.

Второй объектный уровень экспертизы предполагает, что компания-заемщик, проектная компания или инициатор инвестиционного проекта, которая обладает устойчивой способностью исполнять обязательства в настоящее время, но в связи с наличием неудовлетворительных прогнозов с течением времени вероятность неисполнения кредитных обязательств со стороны заемщика или наступления отрицательных параметров реализации проекта возрастает. Денежный поток, генерируемый инвестиционным проектом, подвержен колебаниям. Данная возможность оценивается как умеренная.

Третий объектный уровень - компания-заемщик, проектная компания или инициатор инвестиционного проекта, периодически несвоевременно исполняет обязательства перед коммерческим банком. Допускались просроченные платежи по одному или нескольким 
обязательствам. Денежный поток, генерируемый инвестиционным проектом, неустойчив, вероятность его сокращения, в случае неблагоприятных перемен в финансовых и экономических условиях, высокая. Возможность неисполнения кредитных обязательств со стороны заемщика или наступления отрицательных параметров реализации проекта оценивается как высокая.

Рассмотрим совокупность стандарт-факторов, влияющих на процесс инвестиционно-кредитной экспертизы, связанные со структурой акционерного капитала и внутренней структурой; с кредитной историей и деловой репутацией; с финансовым состоянием; с эффективностью управления; с позицией в отрасли и регионе, производственным оснащением и уровнем использования современных технологий; с выполнением графика реализации инвестиционного проекта и его точного соответствия первоначальным параметрам.

Анализ влияния указанных стандарт-факторов, как предлагают авторы, должен проводится на основании следующей информационно-документальной базы:

1. Учредительные документы (устав, учредительный договор).

2. Сведения об акционерах (участниках, пайщиках, членах) на момент проведения экспертизы и данных об их изменении за последний отчетный период.

3. Данные о дочерних и зависимых организациях.

4. Бухгалтерская отчетность (в отдельных случаях используется управленческая отчетность, заверенная в утвержденном коммерческом банке порядке), в том числе консолидированная в разрезе холдинговой структуры.

5. Информация подразделений коммерческого банка, осуществляющих операции с финансовыми инструментами, в случае если заемщик пользуется иными услугами и банковскими продуктами.

6. Сведения подразделения экономической безопасности о фактах или возможности наступления событий, повлекших за собой финансовые потери и снижение деловой репутации заемщика.

7. Материалы Федеральной службы государственной статистики (общий объем реализации, сальдированный финансовый результат и другие данные в разрезе отраслей, регионов). 


\section{П.П. Князев, М.Н. Клименко, Д.В. Моторнюк}

8. Информация аудиторских компаний, проводивших обязательный или добровольный аудит финансовой отчетности и финансово-хозяйственной деятельности, а также информационных и рейтинговых агентств.

По результатам анализа влияние каждого стандарт-фактора оценивается как низкое, среднее и высокое в соответствии с основными параметрами, определенными предлагаемой экспертной моделью инвестиционного проекта.

Проведем оценку влияния стандарт-факторов, связанных со структурой акционерного капитала и внутренней структурой компании-заемщика, проектной компании или инициатора проекта. Необходимость оценки данных стандарт-факторов объясняется возможностью влияния учредителей, акционеров (собственников) или других лиц на принятие финансовых и управленческих решений по наиболее важным аспектам деятельности компании-заемщика, проектной компании или инициатора проекта. Также это может быть связано с заинтересованностью в изъятии денежных ресурсов, переводу имущественных активов в другие компании, а также необходимостью оказывать не прибыльным дочерним структурам или подразделениям финансовую помощь и содействие.

Сформулируем классификацию основных стандарт-факторов, связанных со структурой акционерного капитала и внутренней структурой компании-заемщика, проектной компании или инициатора проекта. Она строится по следующим направлениям:

1. Степень концентрации акционерного капитала: степень зависимости компании-заемщика, проектной компании или инициатора проекта от политической конъюнктуры; возможность действий топменеджмента в собственных интересах, противоречащих интересам собственников; возможность возникновения спорной ситуации за право оперативного управления компании-заемщика, проектной компании или инициатора проекта несколькими собственниками; влияние, оказываемое собственником, который осуществляет оперативное управление компании-заемщика, проектной компании или инициатора проекта, на деятельность хозяйствующего субъекта, и возможность возникновения конфронтации с остальными акционерами. 
2. Возможность изменений в структуре собственников: оценка возможности и характера потенциального поглощения:

а) мероприятия по фиктивному или умышленному банкротству компании-заемщика, проектной компании или инициатора проекта, в т. ч. в случае недружественного поглощения;

б) снижение или фиксирование операционной и инвестиционной деятельности вследствие смещения центра приложения управленческих решений топ-менеджмента на спорной ситуации;

в) перемещение предыдущими собственниками имущественных активов и денежных ресурсов компании-заемщика, проектной компании или инициатора проекта в контролируемые ими структуры; оценка возможности смены топ-менеджеров, проводимая на основе анализа информации о снижении эффективности управления, операционной и инвестиционной деятельности, смене приоритетных направлений текущей деятельности и развития.

3. Дивидендная политика: оценка возможности влияния на оперативную деятельность компании-заемщика, проектной компании или инициатора проекта собственниками, владеющими привилегированными акциями, в случае невыплаты дивидендов; оценка взаимоотношений топ-менеджмента с собственниками, которые могут оказать воздействие на формирование финансовых потоков компании-заемщика, проектной компании или инициатора проекта при недостаточном размере дивидендов.

4. Характер хозяйственных и финансовых отношений со стратегическими партнерами, т.е. с контрагентами совместно с которыми имеется или осуществляется создание совместной организации, и/или имеются долгосрочные значительные соглашения о совместной деятельности, сроком действия более 1 года и объемом инвестиций более $50 \%$ чистых активов компании-заемщика, проектной компании или инициатора проекта: оценка стратегической значимости партнерства; информационная транспорентность проводимых со стратегическими партнерами операций и сделок; возможное соприкосновения состава топ-менеджмента; оценка фактов взаимодействия в прошлых периодах в целях Расширения и развития; оценка вероятности использования имущественных активов и денежных ресурсов для вливания в деятельность партнера. 


\section{П.П. Князев, М.Н. Клименко, Д.В. Моторнюк}

Авторы предлагают влияние стандарт-факторов экспертизы инвестиционного проекта, связанных со структурой акционерного капитала оценивать по следующей градационной шкале:

Низкое влияние - в случае наличия у компании-заемщика, проектной компании или инициатора проекта крупного акционера или стратегического партнера, оказывающего положительное влияние на деятельность с потенциальным проведением финансовых вливаний. Отсутствие информации о возможном изменении в структуре собственников и противоречий в вопросах, касающихся оперативного управления и принятия стратегических решений. Среднее влияние - в случае наличия незначительных противоречий в вопросах, касающихся оперативного управления и принятия стратегических решений между собственниками или со стратегическими партнерами, или возможности изменения в составе акционеров, негативного влияния основного владельца на деятельность компании-заемщика, проектной компании или инициатора проекта, или отсутствия стратегического инвестора, способного при необходимости оказать финансовую поддержку. Высокое влияние - в случае значительного оттока имущественных активов и денежных средств из компании-заемщика, проектной компании или инициатора проекта под влиянием крупного акционера. Потенциальная возможность недружественного поглощения или необходимости использования ресурсов для поддержки партнера.

С помощью стандарт-факторов, связанных с внутренней структурой оценивается влияние неустойчивости и неэффективности внутренней структуры компании-заемщика, проектной компании или инициатора проекта. Более подробно, как полагают авторы, это возможность потери контроля над дочерними или зависимыми компаниями: прямые финансовые убытки, нарушение производственного цикла, невозможность контроля при проведении дочерними компаниями значительных финансовых сделок, уменьшение консолидированного денежного потока. Кроме того, это возможность оттока имущественных активов и денежных средств в связи с оказанием финансовой помощи дочерним и зависимым компаниям. 
Предлагается влияние стандарт-факторов, связанных с внутренней структурой оценивать по следующей градационной шкале:

Низкое влияние - в случае стабильного финансового положения дочерних и зависимых компаний, осуществления реализации дочерней или зависимой нерентабельной компании. Среднее влияние - угроза потери дочерней и зависимой компании, не оказывающей существенного влияния на деятельность, наличия незначительных финансовых потерь, сокращения консолидированного денежного потока или возможных финансовых трудностей у элементов внутренней структуры, что может негативно отразиться на денежном потоке компании-заемщика, проектной компании или инициатора проекта. Высокое влияние возникает в случае угрозы потери дочерней и зависимой компании, оказывающей существенное влияние на деятельность, наличия значительных финансовых потерь, сокращения консолидированного денежного потока.

Представим оценку влияния стандарт-факторов, связанных с кредитной историей и деловой репутацией компании-заемщика, проектной компании или инициатора проекта. Необходимость проведения анализа объясняется возможностью непосредственного или косвенного влияния этих моментов на финансовые результаты текущей деятельности и инвестиционного проекта, являющимися гарантией выполнения обязательств перед коммерческим банком.

Классификация и оценка основных страндарт-факторов экспертизы инвестиционного проекта, связанных с кредитной историей и деловой репутацией компании-заемщика, проектной компании или инициатора проекта производятся по определенным направлениям. К примеру, стандарт-факторы, связанные с кредитной историей оценивают факты неисполнения компанией-заемщиком, проектной компанией или инициатором проекта своих обязательств перед кредиторами и их влияние на текущую деятельность и дальнейшую реализацию инвестиционного проекта. В частности, это факты просроченных платежей, невозврата или реструктуризации задолженности по кредитным ресурсам, полученным в данном или других коммерческих банков. Дополнительно факты полного или частичного неисполнения обязательств по долговым ценным бумагам; факты неисполнения обязательств перед поставщиками и другими кредиторами. 


\section{П.П. Князев, М.Н. Клименко, Д.В. Моторнюк}

Влияние рассматриваемых стандарт-факторов, связанных с кредитной историей, авторы предлагают оценивать по следующей градационной шкале:

Низкое влияние - в случае наличия продолжительной положительной кредитной истории компании-заемщика, проектной компании или инициатора проекта в коммерческом банке и отсутствия фактов неисполнения своих обязательств перед другими кредиторами, в том числе по долговым ценным бумагам. Среднее влияние - в случае продолжительной положительной кредитной истории компании-заемщика, проектной компании или инициатора проекта в коммерческом банке и единичных фактов нарушения своих обязательств перед другими кредиторами, имевших место на протяжении анализируемого периода или не погашенных на дату проведения экспертизы, или полного отсутствия кредитной истории в кредитной организации. Высокое влияние - в случае отсутствия (наличия непродолжительной положительной) кредитной истории компании-заемщика, проектной компании или инициатора проекта в коммерческом банке и наличия фактов неоднократного неисполнения своих обязательств перед другими кредиторами, не погашенных на дату проведения экспертизы, а также в случае существования фактов несвоевременного погашения основного долга или процентов по кредитам в коммерческом банке.

Стандарт-факторы, связанные с деловой репутацией, оценивают факты наличия негативной информации о деловой репутации компании-заемщика, проектной компании или инициатора проекта и ее влияние на дальнейшую способность отвечать по обязательствам. Авторы их распределяют на факты, связанные с компрометирующими ситуациями, связанными с собственниками или топ-менеджерами, а также с вероятностью их связи с криминальными структурами; факты, связанные с ведением судебных разбирательств или иных санкций в отношении компании-заемщика, проектной компании или инициатора проекта, его собственников или топ-менеджеров.

Влияние стандарт-факторов, связанных с деловой репутацией нужно оценивать по следующей градационной шкале:

Низкое влияние в случае отсутствия информации о санкциях, судебных разбирательствах, компрометирующих ситуаций в отношении 
компании-заемщика, проектной компании или инициатора проекта, о связи его собственников или топ-менеджеров с криминальными структурами. Среднее влияние в случае наличия информации о возможных санкциях, судебных разбирательствах и т.п., последствия которых могут оказать существенное влияние на финансовые результаты деятельности и реализацию инвестиционного проекта, но отсутствует подтверждение данной информации подразделением экономической безопасности коммерческого банка, отсутствия информация об аресте счетов или о наличии исполнительных листов. Высокое влияние в случае подтверждения подразделением экономической безопасности коммерческого банка данной информации.

Рассмотрим оценку влияния стандарт-факторов, связанных с финансовым состоянием и эффективностью текущей деятельности компании-заемщика, проектной компании или инициатора проекта.

Определим необходимость оценки данных стандарт-факторов. Она объясняется важностью идентификации негативных тенденций изменения финансового состояния и показателей текущей деятельности компании-заемщика, проектной компании или инициатора проекта, способных повлиять на исполнение имеющихся обязательств и реализацию инвестиционного проекта.

Классифицировать представляемые стандарт-факторы необходимо по следующим направлениям. В первую очередь, это стандартфакторы, связанные с финансовым состоянием, где на начальном этапе оценивается совокупность показателей, характеризующих наличие, размещение и использование финансовых ресурсов, влияние финансового состояния компании-заемщика, проектной компании или инициатора проекта на способность к погашению обязательств. Оценка производится на основании бухгалтерской отчетности, трансформированной в соответствие с аналитической группировкой и включает расчет и анализ следующих показателей:

1. $\mathrm{K}_{\mathrm{ABT}}-$ коэффициент автономии (уровень самофинансирования);

2. $\mathrm{K}_{\mathrm{p}}$ - операционный рычаг;

3. $\mathrm{K}_{\text {сос }}$ - коэффициент обеспеченности собственными оборотными средствами;

4. $\mathrm{K}_{\text {тек }}$ - коэффициент текущей ликвидности; 
5. К $_{\text {АБс }}$ - коэффициент абсолютной ликвидности;

6. $\mathrm{K}_{\text {рент }}-$ коэффициент рентабельности активов;

7. $\mathrm{K}_{\text {оБ }}$ - коэффициент оборачиваемости активов.

Таблица 1

Расчетные формулы коэффициентов

\begin{tabular}{|c|c|}
\hline Коэффициент & Расчетная формула \\
\hline \multirow[t]{2}{*}{$\mathrm{K}_{\mathrm{ABT}}$} & Собственный капитал \\
\hline & Обязательства + Собственный капитал \\
\hline \multirow[t]{2}{*}{$\mathrm{K}_{\mathrm{p}}$} & Текущие активы \\
\hline & Активы \\
\hline \multirow{2}{*}{$\mathrm{K}_{\mathrm{COC}}$} & Собственный капитал - Внеоборотные активы \\
\hline & Оборотные активы \\
\hline \multirow[t]{2}{*}{$\mathrm{K}_{\mathrm{TEK}}$} & Текущие активы \\
\hline & Краткосрочные обязательства \\
\hline \multirow[t]{2}{*}{$\mathrm{K}_{\mathrm{ABC}}$} & Денежные средства \\
\hline & Краткосрочные обязательства \\
\hline \multirow[t]{2}{*}{$K_{\text {PEHT }}$} & Прибыль до налогообложения \\
\hline & Средняя стоимость активов \\
\hline \multirow[t]{2}{*}{$\mathrm{K}_{\text {ОБ }}$} & Выручка (нетто) \\
\hline & Средняя стоимость активов \\
\hline
\end{tabular}

В зависимости от фактических результатов расчета по каждому коэффициенту определяется его величина.

В соответствии с принципом, заложенным в расчете данных коэффициентов, чем выше фактическое значение коэффициента, тем выше оценка финансового состояния компании-заемщика, проектной компании или инициатора проекта.

Следующим этапом является сопоставление размера коэффициентов и характеристики финансового состояния. 
Сопоставление размера коэффициентов и характеристики финансового состояния

\begin{tabular}{|l|l|}
\hline \multicolumn{1}{|c|}{ Величина коэффициента } & \multicolumn{1}{c|}{ Финансовое состояние } \\
\hline Очень низкий & Предельное неблагополучие \\
\hline Низкий & Неблагополучие \\
\hline Средний & Среднее качество \\
\hline Высокий & Относительное благополучие \\
\hline Очень высокий & Благополучие \\
\hline
\end{tabular}

По результатам проведенного анализа влияние данных стандартфакторов экспертизы инвестиционного проекта оценивается по градационной шкале в зависимости от финансового состояния компании-заемщика, проектной компании или инициатора проекта.

Таблица 3

Оценка влияния стандарт-факторов экспертизы в зависимости от финансового состояния

\begin{tabular}{|l|c|}
\hline \multicolumn{1}{|c|}{ Финансовое состояние } & Влияние факторов мониторинга \\
\cline { 1 - 1 } Предельное неблагополучие & Высокое \\
\cline { 1 - 1 } Неблагополучие & Среднее \\
\cline { 1 - 1 } Среднее качество & Низкое \\
\cline { 1 - 1 } Относительное благополучие & Сльгполуче \\
\hline
\end{tabular}

Если рассматривать стандарт-факторы экспертизы, связанные с эффективностью текущей деятельности, то на последующем этапе нужно оценивать возможность ухудшения финансового состояния компании-заемщика, проектной компании или инициатора проекта в будущем. Среди них возможные причины константных или временных 
отрицательных тенденций снижения показателей оценки финансового состояния; снижение эффективности текущей деятельности компании-заемщика, проектной компании или инициатора проекта. Это может происходить за счет превышения темпа роста дебиторской задолженности и краткосрочных обязательств над темпом роста выручки от реализации, а также снижения значения показателей рентабельности продукции и оборачиваемости активов.

Таблица 4

Расчет показателей оборачиваемости

\begin{tabular}{|c|c|c|}
\hline Показатель & $\mathrm{Ha}$ & Расчетная формула \\
\hline $\begin{array}{l}\text { Оборачивае- } \\
\text { мость текущих } \\
\text { активов }\end{array}$ & $\begin{array}{l}\text { Продолжительность } \\
\text { одного оборота теку- } \\
\text { щих активов }\end{array}$ & $\begin{array}{c}\text { Средняя величина } \\
\frac{\text { текущих активов (квартальная) }}{\text { Объем реализации за день }}\end{array}$ \\
\hline $\begin{array}{l}\text { Оборачи- } \\
\text { ваемость } \\
\text { собственного } \\
\text { капитала }\end{array}$ & $\begin{array}{l}\text { Продолжительность } \\
\text { одного оборота денеж- } \\
\text { ных средств, которыми } \\
\text { рискуют акционеры }\end{array}$ & $\begin{array}{c}\text { Средняя величина } \\
\frac{\text { собственного капитала (квартал) }}{\text { Объем реализации за день }}\end{array}$ \\
\hline $\begin{array}{l}\text { Оборачивае- } \\
\text { мость матери- } \\
\text { ально-произ- } \\
\text { водственных } \\
\text { запасов, в том } \\
\text { числе: } \\
\text { производ- } \\
\text { ственных } \\
\text { запасов; }\end{array}$ & $\begin{array}{l}\text { Продолжительность цик- } \\
\text { ла, в течение которого } \\
\text { материально-производ- } \\
\text { ственные запасы пре- } \\
\text { вращаются в денежную } \\
\text { наличность, в том числе: } \\
\text { производственные } \\
\text { запасы; }\end{array}$ & $\begin{array}{c}\text { Средняя стоимость } \\
\text { материально-производственных } \\
\text { запасов (квартальная) } \\
\text { Себестоимость реализованной } \\
\text { продукции, соответствующая } \\
\text { объему реализации за день } \\
\text { Средняя стоимость } \\
\text { производственных запасов } \\
\text { Себестоимость реализованной } \\
\text { продукции, соответствующая } \\
\text { объему реализации за день } \\
\text { Средняя } \\
\text { стоимость готовой продукции } \\
\text { Себестоимость реализованной } \\
\text { продукции, соответствующая } \\
\text { объему реализации за день }\end{array}$ \\
\hline
\end{tabular}


Общеизвестно, что показатели оборачиваемости активов отражают скорость обращения активов компании-заемщика, проектной компании или инициатора проекта в денежную форму, оказывающую непосредственное влияние на платежеспособность. Для целей анализа оборачиваемости следует производить расчет показателей оборачиваемости текущих активов, собственного капитала и материально-производственных запасов.

Влияние этих стандарт-факторов можно оценивать по следующей градационной шкале:

Низкое влияние в случае если не наблюдается отрицательных тенденций. Среднее влияние в случае если наблюдаются отдельные отрицательные тенденции, не имеющие константного характера. Высокое влияние в случае если наблюдаются отрицательные тенденции, имеющие константный устойчивый характер.

Далее проведем оценку влияния стандарт-факторов, связанных с эффективностью управления компании-заемщика, проектной компании или инициатора проекта, соответствием требованиям финансовой прозрачности и качеству предоставления информации, а также влиянием налогового риска. Необходимость оценки данных стандарт-факторов экспертизы объясняется возможностью ухудшения финансовых взаимоотношений компании-заемщика, проектной компании или инициатора проекта с контрагентами вследствие неэффективного управления и вероятностью необъективной оценки коммерческим банком финансовой отчетности.

С помощью этих стандарт-факторов следует оценивать управление денежным хозяйством, финансовыми и операционными рисками текущей деятельности и реализации инвестиционного проекта, а также персоналом компании, задействованном в текущей деятельности и в проектной группе.

Влияние этих стандарт-факторов экспертизы, связанных с эффективностью управления, представляется по следующей градационной шкале:

Низкое влияние в случае осуществления последовательной и согласованной политики управления денежными денежным хозяйством, финансовыми и операционными рисками, а также при наличии устойчивого состава топ-менеджеров и сотрудников проектной 
группы, осуществляющей реализацию инвестиционного проекта. Среднее влияние в случае осуществления неэффективной политики управления денежными денежным хозяйством, финансовыми и операционными рисками, итогами которой являются недостижение поставленных целей деятельности, а также в результате отсутствия устойчивой группы специалистов. Высокое влияние в случае наличия отрицательной информации при оценке указанных аспектов.

Коммерческий банк рассматривает соответствие требованиям финансовой прозрачности и качеству предоставления информации. В частности, если компания-заемщик, проектная компания или инициатор проекта входят в холдинговую структуру, необходимо предоставление консолидированной отчетности. Положительным моментом является наличие бухгалтерской отчетности, подготовленной по Международным стандартам финансовой отчетности, подтвержденной в установленном порядке независимой аудиторской компанией. Дополнительно может публиковаться информация о текущей деятельности и реализации инвестиционного проекта. Важным моментом является достоверность финансовой информации и предоставление всех необходимых массивов данных в коммерческий банк.

Влияние этих стандарт-факторов можно оценивать по следующей градационной шкале:

Низкое влияние в случае предоставления всей требуемой коммерческим банком информации, с обеспечением прозрачности текущей деятельности компании-заемщика, проектной компании или инициатора проекта и реализации инвестиционного проекта. Среднее влияние в случае частичной информационной непрозрачности отдельных аспектов текущей деятельности компании-заемщика, проектной компании или инициатора проекта. Высокое влияние в случае полной информационной непрозрачности текущей деятельности.

Стандарт-факторы экспертизы, связанные с влиянием налогового риска, можно представлять, если есть реструктуризированная или просроченная задолженность перед бюджетной системой, итоговые результаты налоговых проверок, штрафные санкции.

По градационной шкале низкое влияние будет в случае отсутствия у компании-заемщика, проектной компании или инициатора 
проекта задолженности перед бюджетной системой за анализируемый период и штрафных санкций. Среднее влияние в случае наличия незначительной просроченной задолженности перед бюджетной системой, погашение которой осуществляется в соответствии с утвержденным графиком. Высокое влияние в случае наличия весомой просроченной задолженности, которая своевременно не погашается, не согласован график ее реструктуризации.

Представим оценку влияния стандарт-факторов, связанных с позицией в отрасли и регионе, производственным оснащением и уровнем использования современных технологий.

Эти стандарт-факторы чрезвычайно важны. Авторы считают, что это объясняется непосредственной зависимостью финансового результата текущей деятельности компании-заемщика, проектной компании или инициатора проекта и реализации инвестиционного проекта от рыночной позиции и высокого уровня технической и технологической оснащенности.

Через стандарт-факторы, связанные с позицией в отрасли и регионе оценивается возможность и влияние сокращения занимаемого рыночного сегмента на способность компании-заемщика, проектной компании или инициатора проекта отвечать по обязательствам и реализацию инвестиционного проекта. При этом учитывается уровень конкуренции в отрасли и на региональном сегменте рынка в частности - анализ позиций основных отраслевых и региональных конкурентов и агрессивности их политики по расширению доли рынка. Существенное значение имеет неустойчивость и постоянная трансформация занимаемой доли рынка. Также определяется уровень диверсификации потребителей и поставщиков продукции - оценка зависимости от ограниченного числа потребителей и поставщиков.

Влияние этих стандарт-факторов оценивается как низкое в случае, если компания-заемщик, проектная компания или инициатор проекта устойчиво занимает фиксированный рыночный сегмент, имеет расширенную сеть поставщиков и потребителей. В случае если компания-заемщик, проектная компания или инициатор проекта не занимает лидирующих рыночных, но имеет значительное число поставщиков сырья и потребителей продукции при высоком уровне 
конкуренции, авторы считают влияние средним. Соответственно как высокое в случае, если наблюдается неустойчивость или постоянное снижение положения на рынке, существует значительная зависимость от неплатежеспособных поставщиков и потребителей, сопровождаемая высоким уровнем конкуренции.

Посредством стандарт-факторов экспертизы, связанных с производственным оснащением и уровнем использования современных технологий оценивается влияние на уровень технической и технологической оснащенности. Проводится анализ вероятности появления технического или технологического отставания компании-заемщика, проектной компании или инициатора проекта от основных конкурентов. Одновременно изучаются масштабы использования современных технологий, в сравнительном аспекте со среднеотраслевой ситуацией. Обязательным, по мнению авторов, является наличие программы инвестиционных вложений, в том числе на развитие материально-технической базы, разработанной с учетом приемлемой степени риска, отраслевых особенностей и специфики текущей деятельности и реализации инвестиционного проекта.

Влияние рассмотренных стандарт-факторов оценивается как низкое в случае отсутствия технического или технологического отставания от конкурентов, нахождения на уровне среднеотраслевой ситуации, наличия у компании-заемщика, проектной компании или инициатора проекта программы инвестиционных вложений. Среднюю оценку проставляем в случае наличия незначительного технического или технологического отставания от среднеотраслевого уровня и уровня конкурентов, при наличии программы инвестиционных вложений со значительными объемами затрат, направленными на преодоление данного несоответствия, в т.ч. освоение новых направлений деятельности. Высокое влияние возникает в случае значительного технического или технологического отставания компании-заемщика, проектной компании или инициатора проекта от среднеотраслевого уровня или от уровня конкурентов, а также при существовании законсервированных производственных мощностей. 
Значимый интерес возникает у коммерческого банка при оценке влияния стандарт-факторов, связанных с выполнением графика реализации инвестиционного проекта и его точного соответствия первоначальным параметрам. Необходимость оценки данных стандарт-факторов экспертизы объясняется прямой взаимосвязью реализации инвестиционного проекта и величины кредитного риска коммерческого банка, транслирующего возможность компании-заемщика, проектной компании или инициатора проекта своевременно и в полном объеме выполнять обязательства. Эти стандарт-факторы несут вероятность изменения первоначальных проектных параметров, что может оказать отрицательное воздействие вследствие увеличения сроков или объемов расходов.

К числу названных стандарт-факторов авторы относят: выполнение графика реализации по мероприятиям и финансовым контрольным точкам, т.е. своевременное выполнение поставки и необходимых работ следующее параллельному расходованию денежных ресурсов; изменение контрагентов, осуществляющих реализацию инвестиционного проекта (генерального подрядчика, поставщиков и т.д.); кардинальная трансформация первоначальных параметров инвестиционного проекта, касающаяся его масштабов, технической и технологической сторон.

Авторами данные стандарт-факторы оцениваются как низкие в случае, если реализация инвестиционного проекта проводится в рамках графика, в соответствие с мероприятиями и финансовыми контрольными точками, по первоначальным параметрам, фиксированным при принятии коммерческим банком решения о предоставлении кредитных ресурсов. Среднее влияние - если реализация инвестиционного проекта проводится со смещением во времени и незначительным удорожанием, полученным по форс-мажорным обстоятельствам, потребовавшим частичное изменение первоначальных параметров. Высокое влияние - если реализация инвестиционного проекта проводится с кардинальным изменением графика и первоначальных параметров, что может являться причиной невыполнения компанией-заемщиком, проектной компанией или инициатором проекта обязательств перед коммерческим банком. 
Значимость факторов, для включения компании-заемщика, проектной компании или инициатора проекта в группу мониторинга

\begin{tabular}{|c|c|}
\hline Стандарт-факторы экспертизы & $\begin{array}{l}\text { Значимость для } \\
\text { определения уров- } \\
\text { ня экспертизы }\end{array}$ \\
\hline 1 & 2 \\
\hline \multicolumn{2}{|c|}{$\begin{array}{l}\text { Факторы, связанные со структурой акционерного капитала и внутренней } \\
\text { структурой компании-заемщика, проектной компании или инициатора проекта }\end{array}$} \\
\hline Структура акционерного капитала & $5 \%$ \\
\hline Внутренняя структура & $5 \%$ \\
\hline \multicolumn{2}{|c|}{$\begin{array}{c}\text { Факторы, связанные с кредитной историей и деловой репутацией } \\
\text { компании-заемщика, проектной компании или инициатора проекта }\end{array}$} \\
\hline Кредитная история & $5 \%$ \\
\hline Деловая репутация & $5 \%$ \\
\hline \multicolumn{2}{|c|}{$\begin{array}{c}\text { Факторы, связанные с финансовым состоянием и эффективностью } \\
\text { текущей деятельности компании-заемщика, проектной компании } \\
\text { или инициатора проекта }\end{array}$} \\
\hline Финансовое состояние & $15 \%$ \\
\hline Эффективность текущей деятельности & $15 \%$ \\
\hline \multicolumn{2}{|c|}{$\begin{array}{c}\text { Факторы, связанные с эффективностью управления компании-заемщика, } \\
\text { проектной компании или инициатора проекта, соответствием } \\
\text { требованиям финансовой прозрачности и качеству предоставления } \\
\text { информации, а также влиянием налогового риска }\end{array}$} \\
\hline Эффективность управления & $10 \%$ \\
\hline $\begin{array}{l}\text { Финансовая прозрачность и качество предоставле- } \\
\text { ния информации }\end{array}$ & $10 \%$ \\
\hline Налоговый риск & $5 \%$ \\
\hline
\end{tabular}


Окончание табл . 5

\begin{tabular}{|l|c|}
\hline \multicolumn{1}{|c|}{1} & 2 \\
\hline \multicolumn{2}{|c|}{$\begin{array}{c}\text { Факторы, связанные с позицией в отрасли и регионе, производственным } \\
\text { оснащением и уровнем использования современных технологий }\end{array}$} \\
\hline $\begin{array}{l}\text { Позиция в отрасли и регионе } \\
\text { Производственное оснащение и уровень использова- } \\
\text { ния современных технологий }\end{array}$ & $5 \%$ \\
\hline $\begin{array}{l}\text { Факторы, связанные с выполнением графика реализации инвестиционного } \\
\text { проекта и его точного соответствия первоначальным параметрам, } \\
\text { фиксированным при принятии коммерческим банком решения }\end{array}$ \\
\hline \multicolumn{2}{|c|}{ о предоставлении кредитных ресурсов } \\
\hline $\begin{array}{l}\text { Выполнение графика реализации инвестиционного про- } \\
\text { екта, точное соответствие первоначальным параметрам }\end{array}$ \\
\hline
\end{tabular}

Подведем итоги комплексной оценки стандарт-факторов. Авторы считают важным провести дифференциацию компаний-заемщиков, проектных компаний или инициаторов проекта по уровню факторного влияния.

Установим адаптивный показатель определения уровня экспертизы $\boldsymbol{A}$ с учетом влияния всех рассмотренных стандарт-факторов на способность компании-заемщика, проектной компании или инициатора проекта исполнять обязательства перед коммерческим банком.

Показатель $A$ определяется по формуле:

$$
A=0,025 \times F_{1}+0,25 \times F_{2}+0,50 \times F_{3}+0,70 \times F_{4}+0,87 \times F_{5}+0,98 \times F_{6},
$$

где $F_{i}$ - количество попаданий в $i$ - группу, взвешенное с учетом значимости стандарт-фактора.

В зависимости от фактического значения, которое принимает адаптивный показатель $A$, осуществляется отнесение компании-заемщика, проектной компании или инициатора проекта к определенной группе экспертизы. 


\section{РЕКОМЕНДУЕМАЯ ЛИТЕРАТУРА}

1. Анализ финансового состояния и инвестиционной привлекательности предприятия: Учеб. пособие / Э.И. Крылов, В.М. Власова, М.Г. Егорова и др. - М.: Финансы и статистика, 2013. - 192 с.

2. Бабич А.М., Павлова Л.Н. Финансы. Денежное обращение. Кредит. - М., 2016. - 312 с.

3. Балабанов И.Т. Основы финансового менеджмента. М.: Финансы и статистика, 2016. - 235 с.

4. Банковское дело. / Под ред. О.И. Лаврушина. - М., 2018. - 469 с.

5. Банковское дело: управление и технологии. / Под ред. проф. А.М. Тавасиева. - М., 2017. - 895 с.

6. Беренс В., Хавронек П.М. Руководство по оценке эффективности инвестиций / Пер, с англ. М.: Инфра - М, 2005. - 287с.

7. Бернар И., Колли Ж.-К. Толковый экономический и финансовый словарь: Пер. с фр.: В 2т. - М., 2004. - 1200 с.

8. Бизнес: Оксфордский толковый словарь: англо-русский. - М.: Прогресс-Академия; изд-во РГГУ, 2005. - 623 с.

9. Бизнес-планирование: Учебник/ Под ред. В.М. Попова и С.И. Ляпунова. - М.: Финансы и статистика, 2016. - 672 с.

10. Бланк И.А. Инвестиционный менеджмент. Учеб. курс. Киев: Ника-Центр, Эльга, 2010. - 456 с.

11. Боди Зви, Мертон Роберт. Финансы: Пер. с англ.: Учеб. пособие. - М.: Издательский дом «Вильямс», 2018. - 592 с.

12. Большаков С.В. Основы управления финансами: Учебное пособие. М.: ИД ФБК - ПРЕСС, 2015. - 368 с.

13. Бочаров В.В. Инвестиции. Учеб. для вузов. СПб: Питер, 2016. - 343 c.

14. Брейли Р., Майерс С. Принципы корпоративных финансов: Пер. с англ. М: 3 АО ««Олимп-Бизнес», 2007. - 654 с. 
15. Бригхем Ю., Гапенски Л. Финансовый менеджмент: Пер. с англ. / Под ред. В.В. Ковалева. СПб.: Экономическая школа, 2007. - 943 с.

16. Ван.Хорн.Дж. Основы управления финансами: Пер. с англ. М.: Финансы и статистика, 2006. - 453 с.

17. Галаненко В.П., Самарина Г.П., Страхова О.А. Бизнес - планирование. СПб.: Питер, 2014. - 205 с.

18. Гитман Л.Дж., Джонк М.Д. Основы инвестирования. М.: Дело, 2007. -345 c.

19. Доунс Д., Гудман Д. Финансово-инвестиционный словарь. М.: ИНФРА-М, 2007. - 348 с.

20. Инвестиции: Учебник / Под ред. В.В. Ковалева, В.В. Иванова, В.А. Лялина. М.: 2016. - 440 с.

21. Коссов В.В. Бизнес - план: обоснование решений: Учебное пособие. М.: ГУ ВШЭ, 2017. - 272 с.

22. Деньги, кредит, банки. Под ред. О.И. Лаврушина. - М., 2017. -420 c.

23. Леонтьев В.Е., Радковская Н.П. Финансы, деньги, кредит и банки. - СПб., 2013. - 598 с.

24. Макконнелл К.Р., Брю С.Л. Экономикс: В 2 т. - М.: Республика, 2012.

25. Мескон М., Альберт М., Хедоури Ф. Основы менеджмента / Пер, с англ. М.: Дело, 2005. - 701 с.

26. Островская О.М. Банковское дело: Толковый словарь. - М., 2009.-399 c.

27. Розенберг Дж.М. Инвестиции: Терминологический словарь. М.: Инфра М, 2007. - 740 с.

28. Сенчагов В.К., Архипов А.И. и др. Финансы, денежное обращение и кредит. - М., 2017. - 655 с.

29. Словарь современной экономической теории Макмиллана. М.: Инфра-М, 2007. - 855 с. 
30. Современный финансово-кредитный словарь / Под ред. М.Г. Лапусты, П.С.Никольского. М.: ИНФРА-М, 2009. - 325 с.

31. Современный экономический словарь / Под ред. Райзберг Б.А. - М.: Инфра М, 2007. - 553 с.

32. Финансы. Денежное обращение. Кредит. Под ред. проф. Г.Б. Поляка. - М., 2016. - 498 с.

33. Финансы. Денежное обращение. Кредит: Учебник для вузов / Л.А. Дробозина, Л.Д. Окунева, Л.Д. Андросова и др.; Под ред. проф. Л.А. Дробозиной. М.:ЮНИТИ, 2015.-.479 с.

34. Финансы и кредит. / Под ред. проф. М.В. Романовского, проф. Г.Н. Белоглазовой. - М., 2018. - 623 с.

35. Финансы: Учебник для вузов. Под ред. проф. М.В. Романовского, проф. О.В. Врублевской, проф. Б.М. Сабанти. М.: Издательство «Перспектива; Издательство Юрайт», 2006. - 520 с.

36. Финансово-кредитный энциклопедический словарь / Колл. авторов; Под общ. ред. А.Г. Грязновой. - М., 2012. - 785 с.

37. Шарп У.Ф., Александер Г.Дж., Бэйли Дж. Инвестиции: Пер. с англ. М.: Инфра-М, 2007. - 321 с.

38. http://government.ru.

39. http://minpromtorg.gov.ru.

40. https://www.minfin.ru/ru.

41. http://economy.gov.ru/minec/main.

42. http://www.gks.ru.

43. https://www.cbr.ru. 


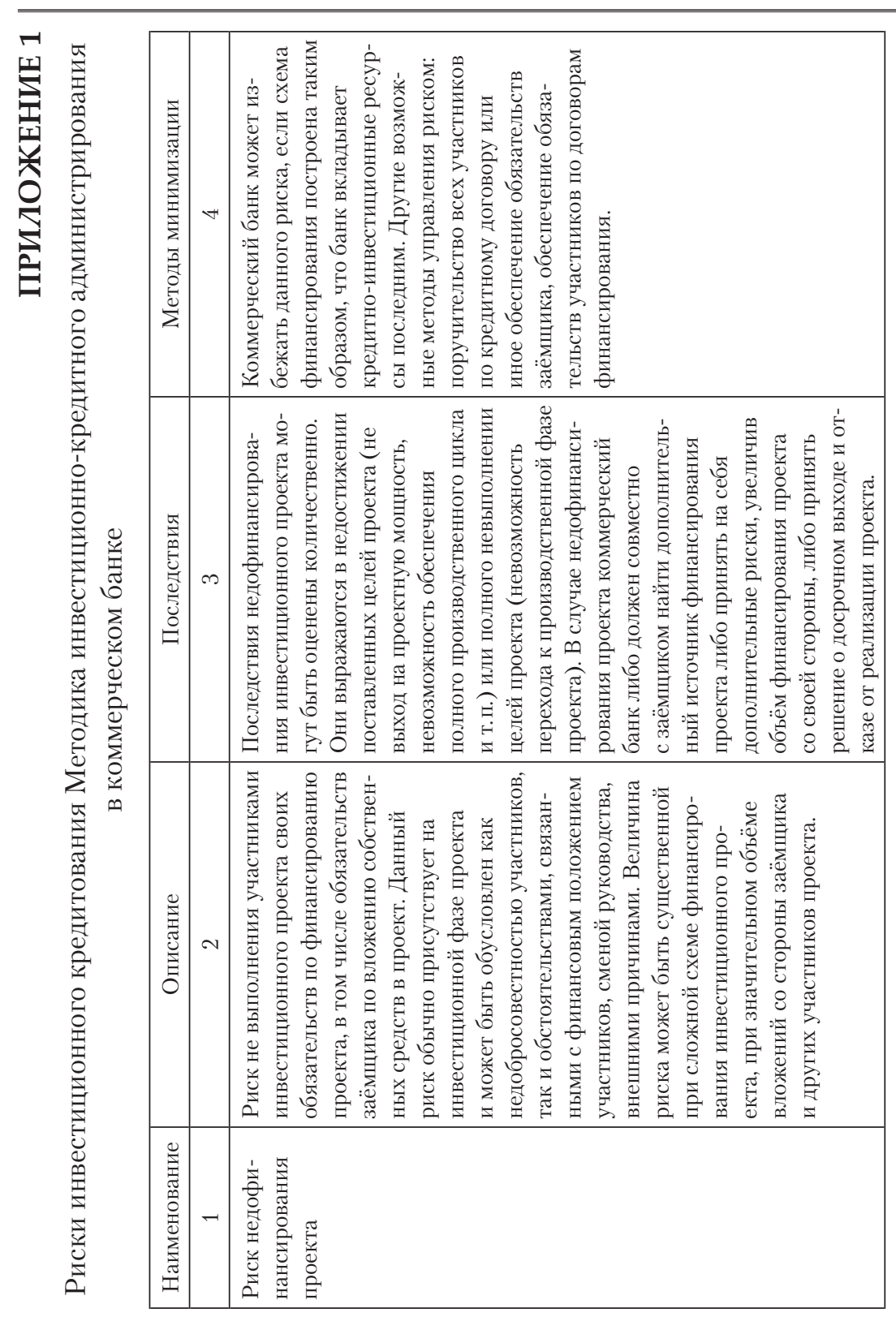




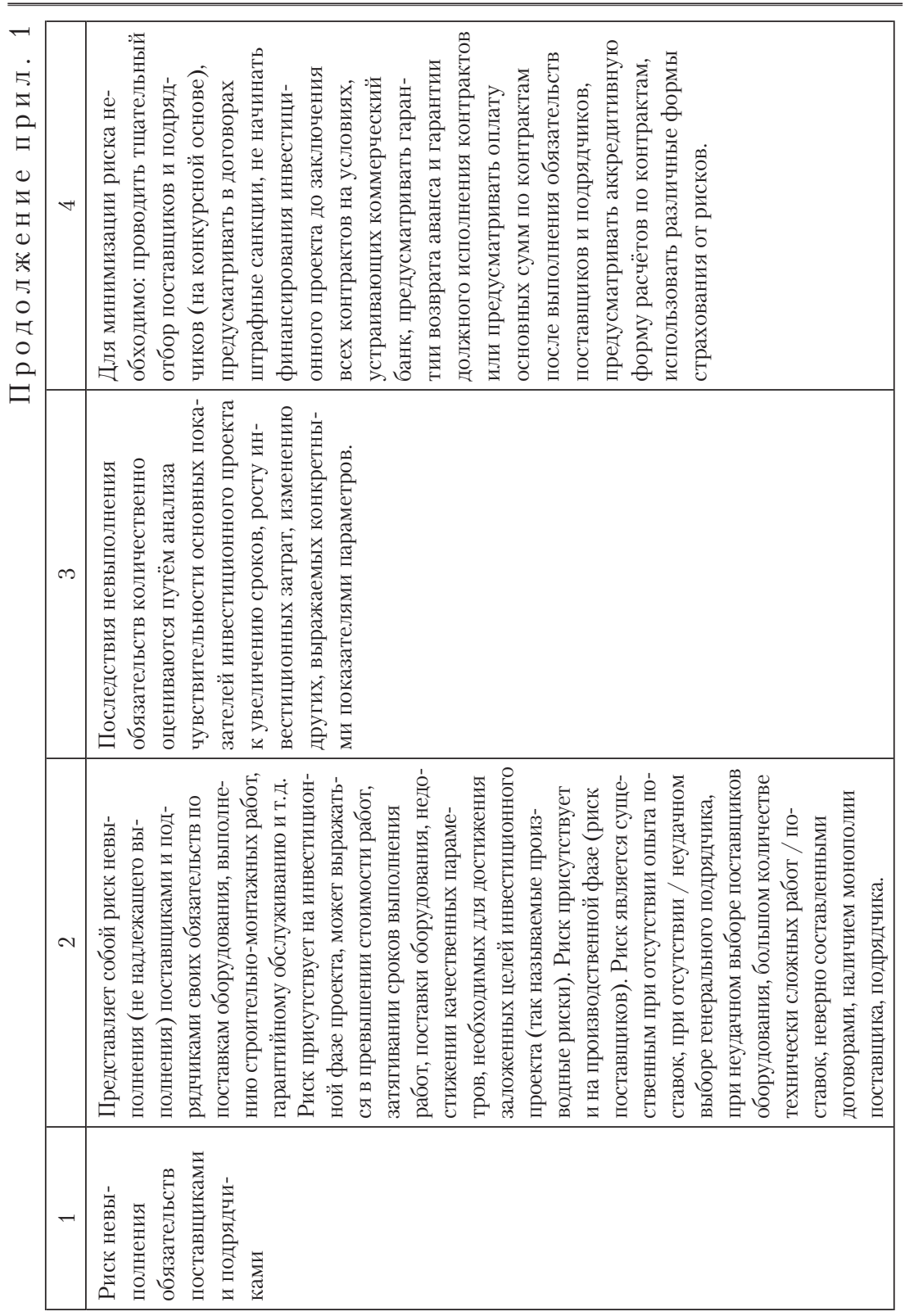




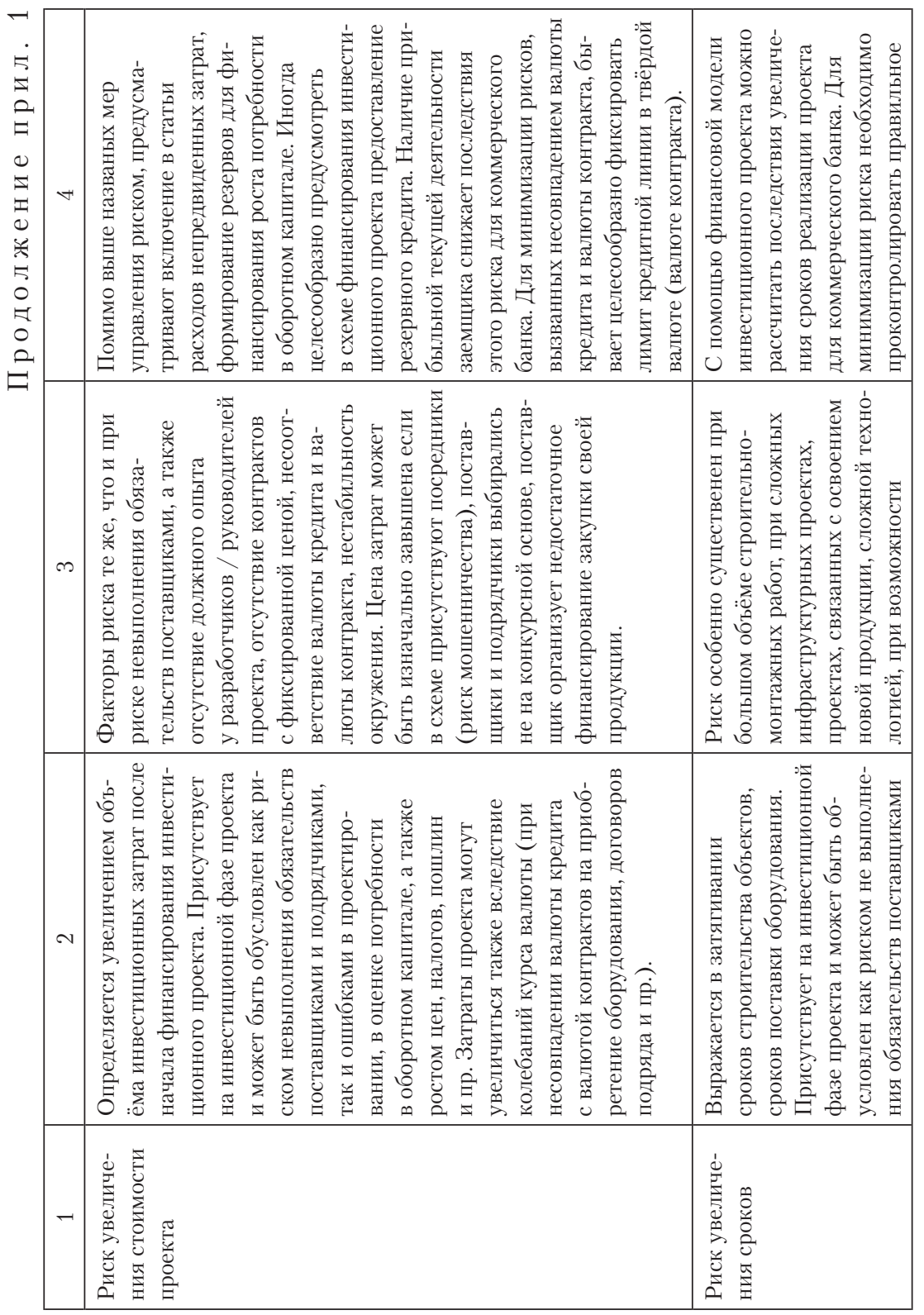




\section{П.П. Князев, М.Н. Клименко, Д.В. Моторнюк}

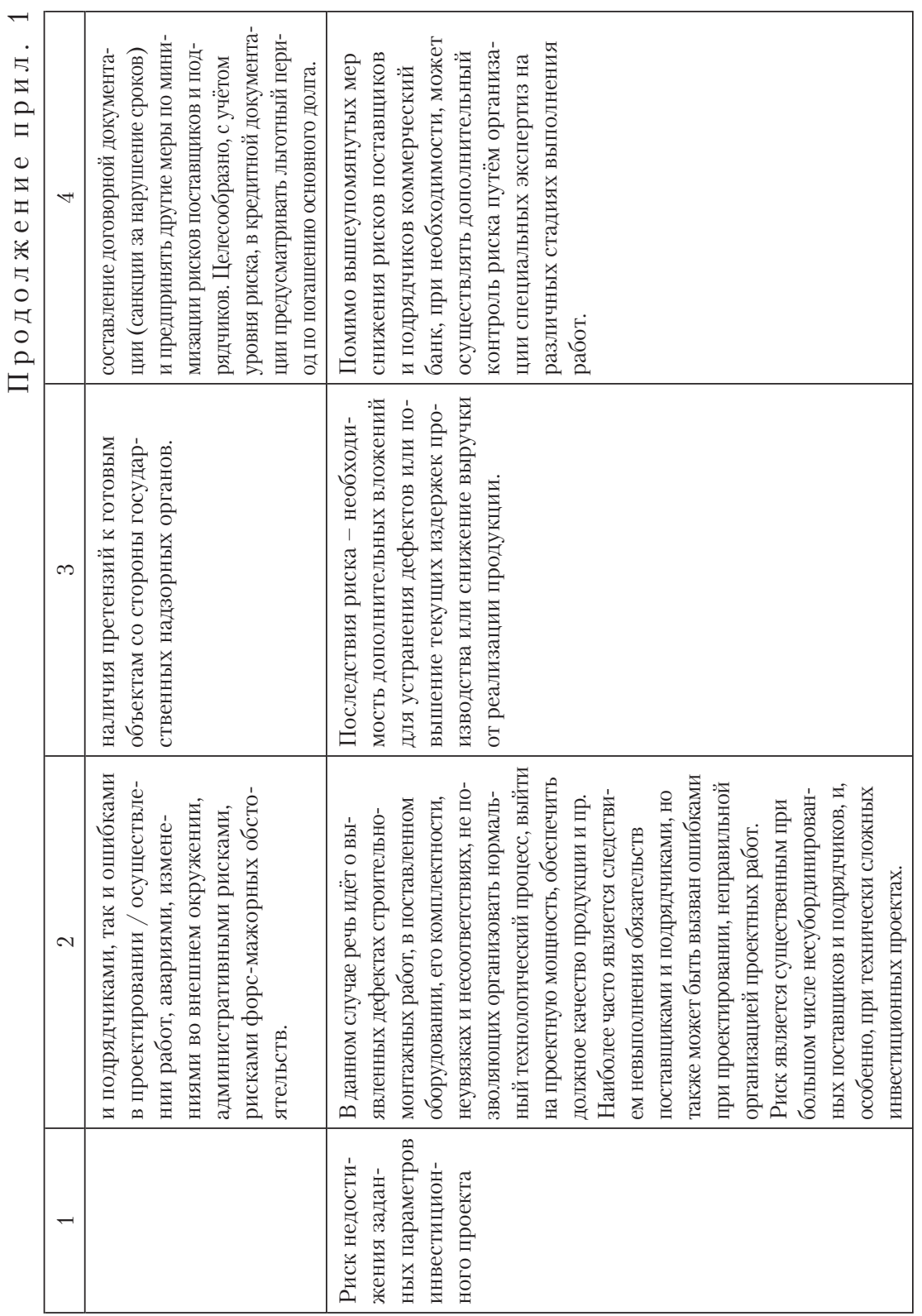




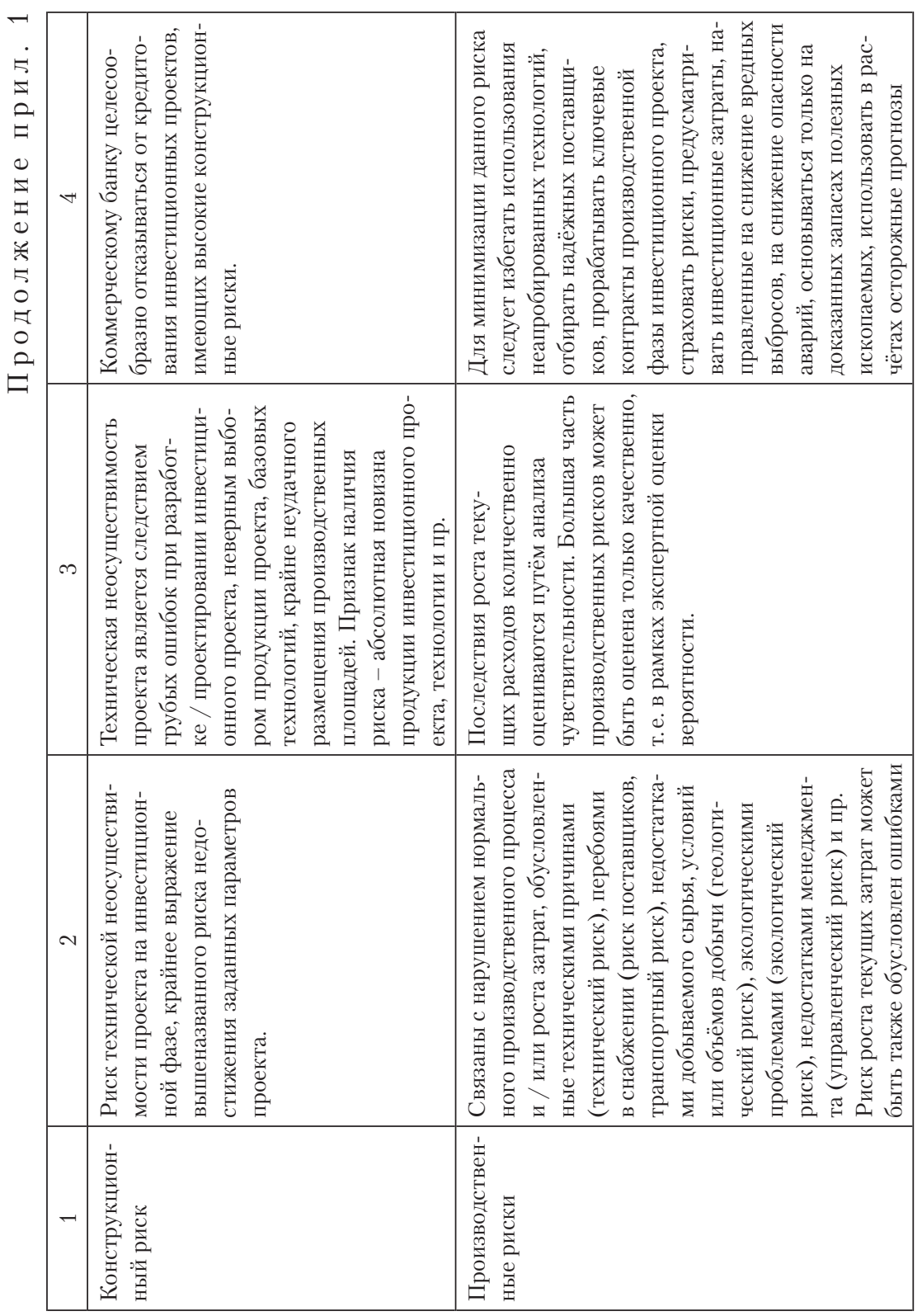




\section{П.П. Князев, М.Н. Клименко, Д.В. Моторнюк}

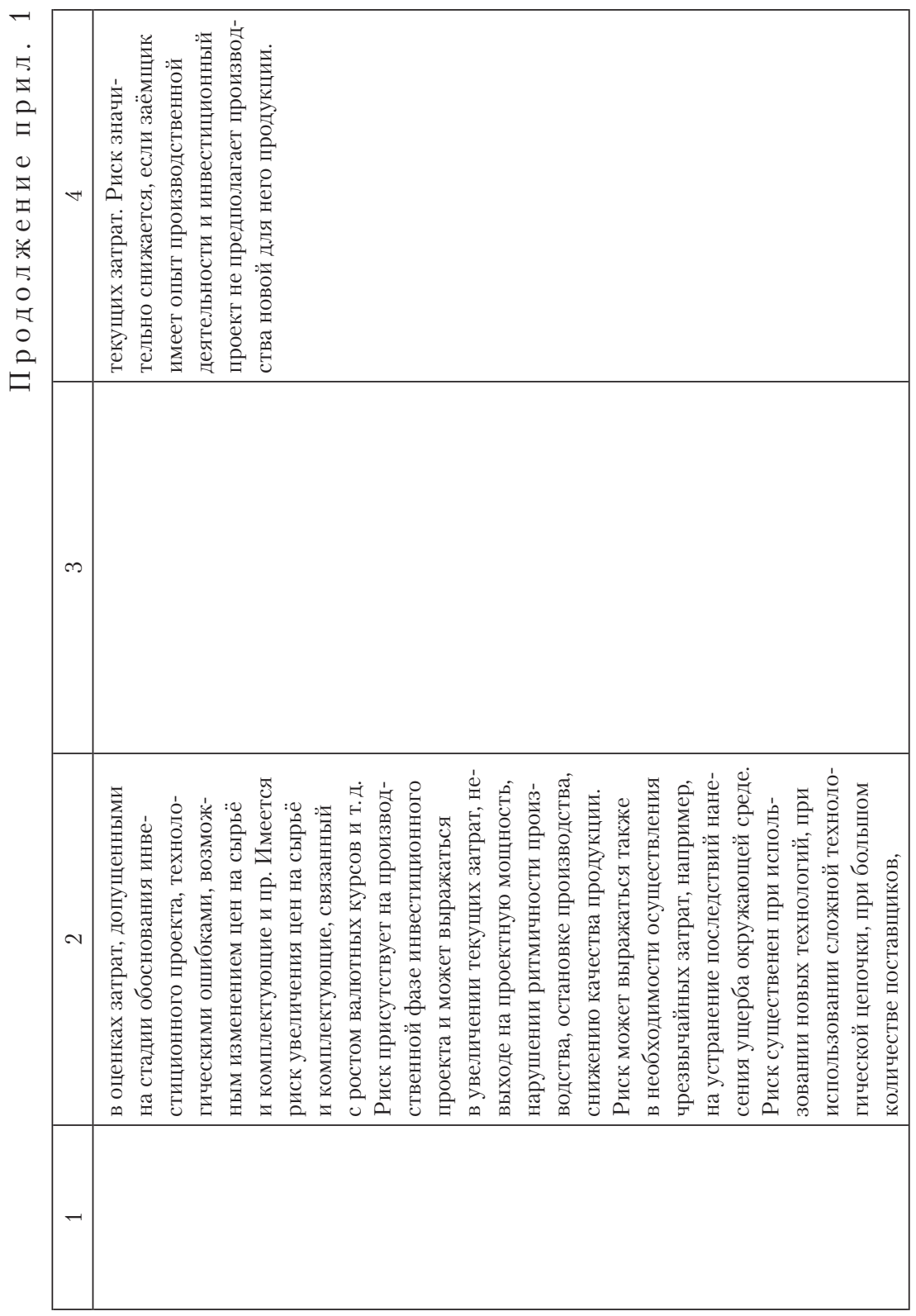




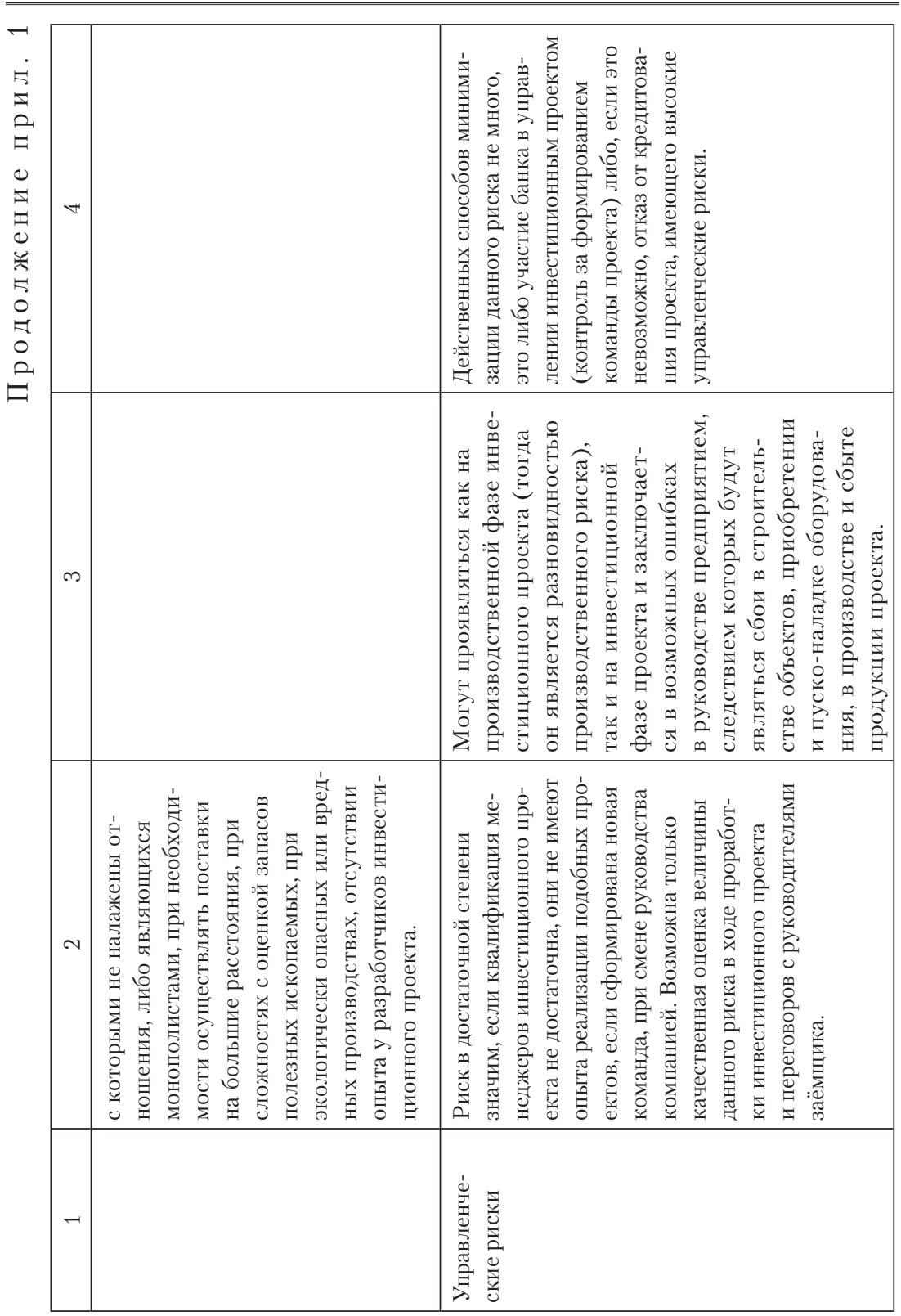




\section{П.П. Князев, М.Н. Клименко, Д.В. Моторнюк}

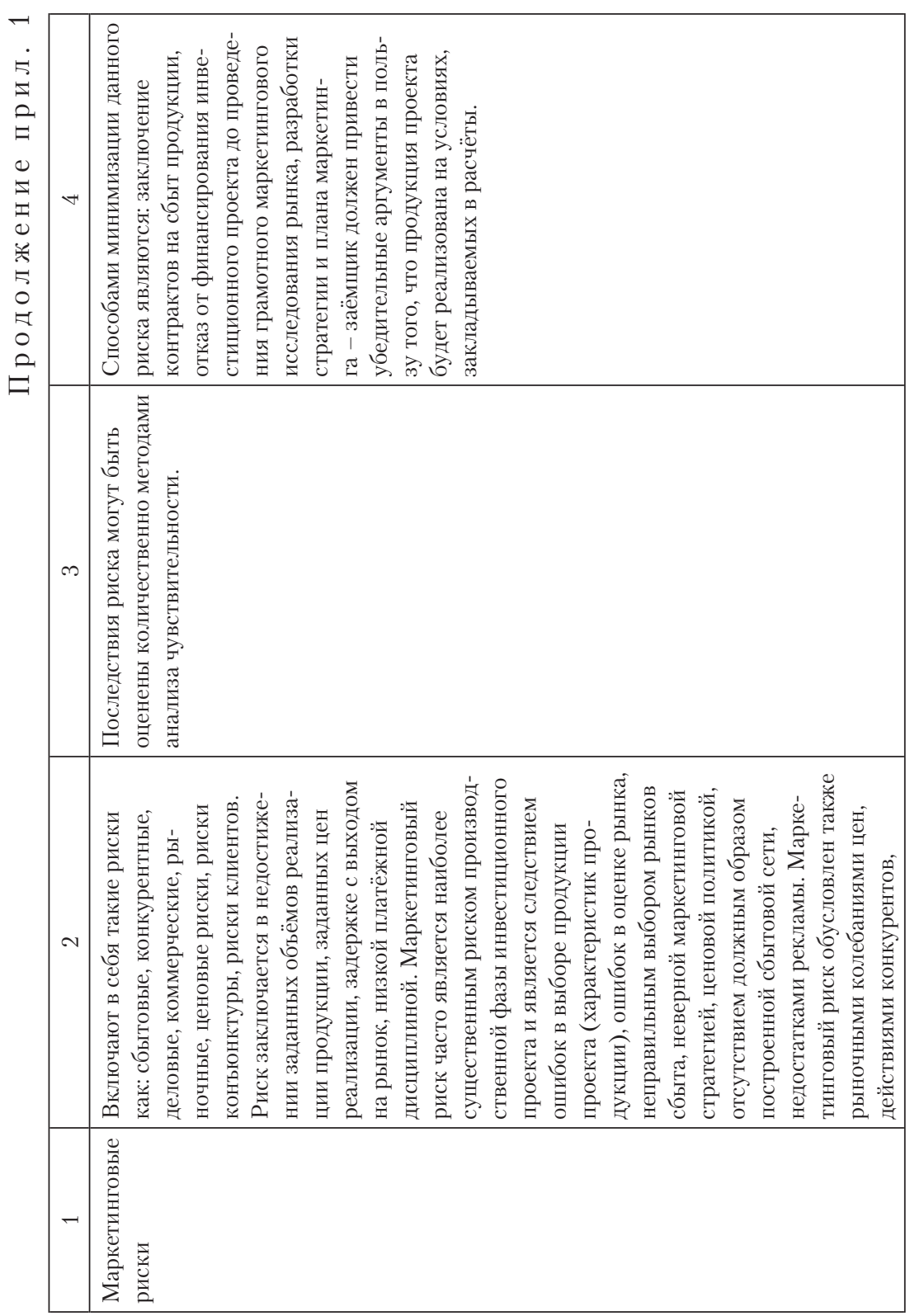




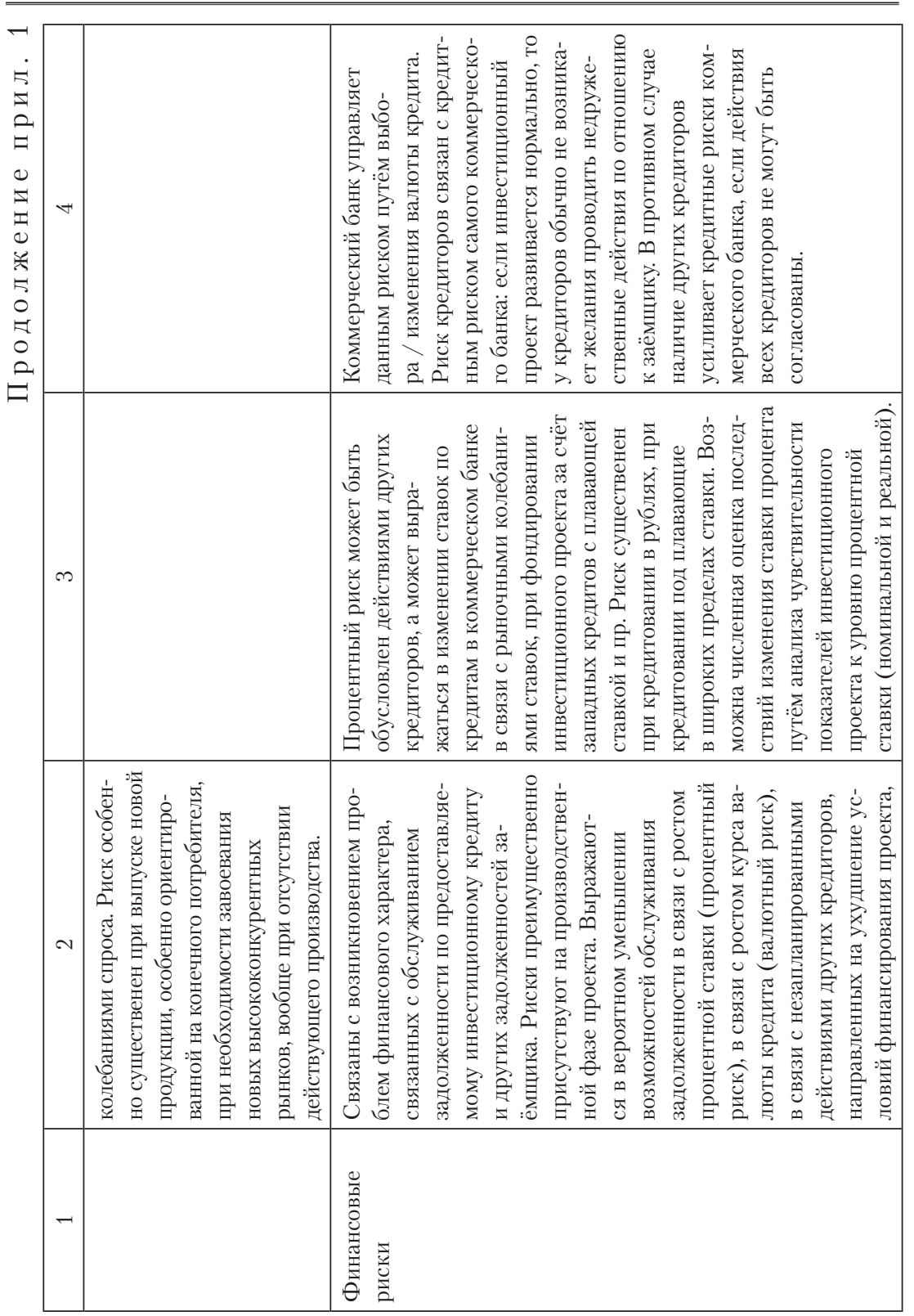




\section{П.П. Князев, М.Н. Клименко, Д.В. Моторнюк}

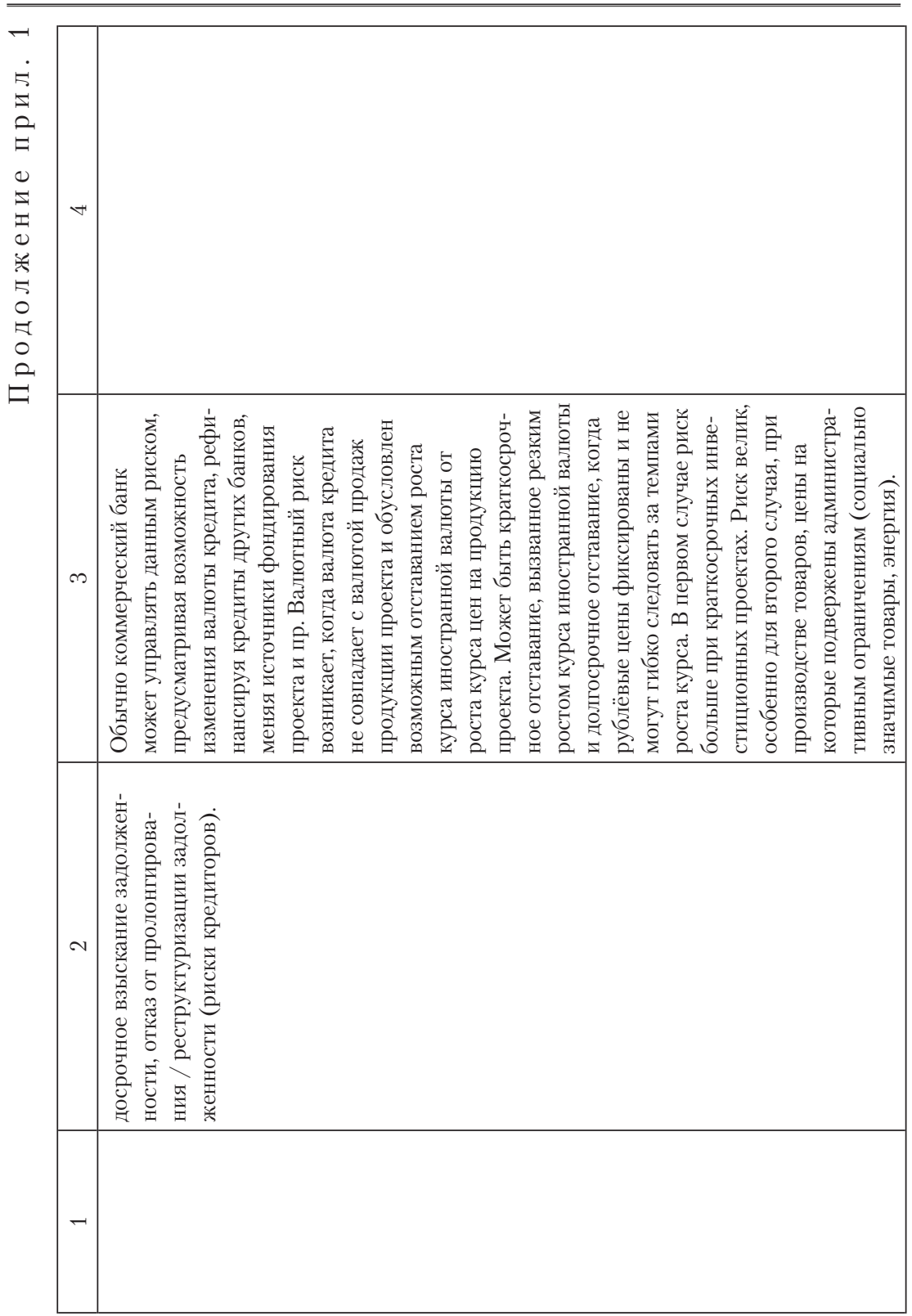




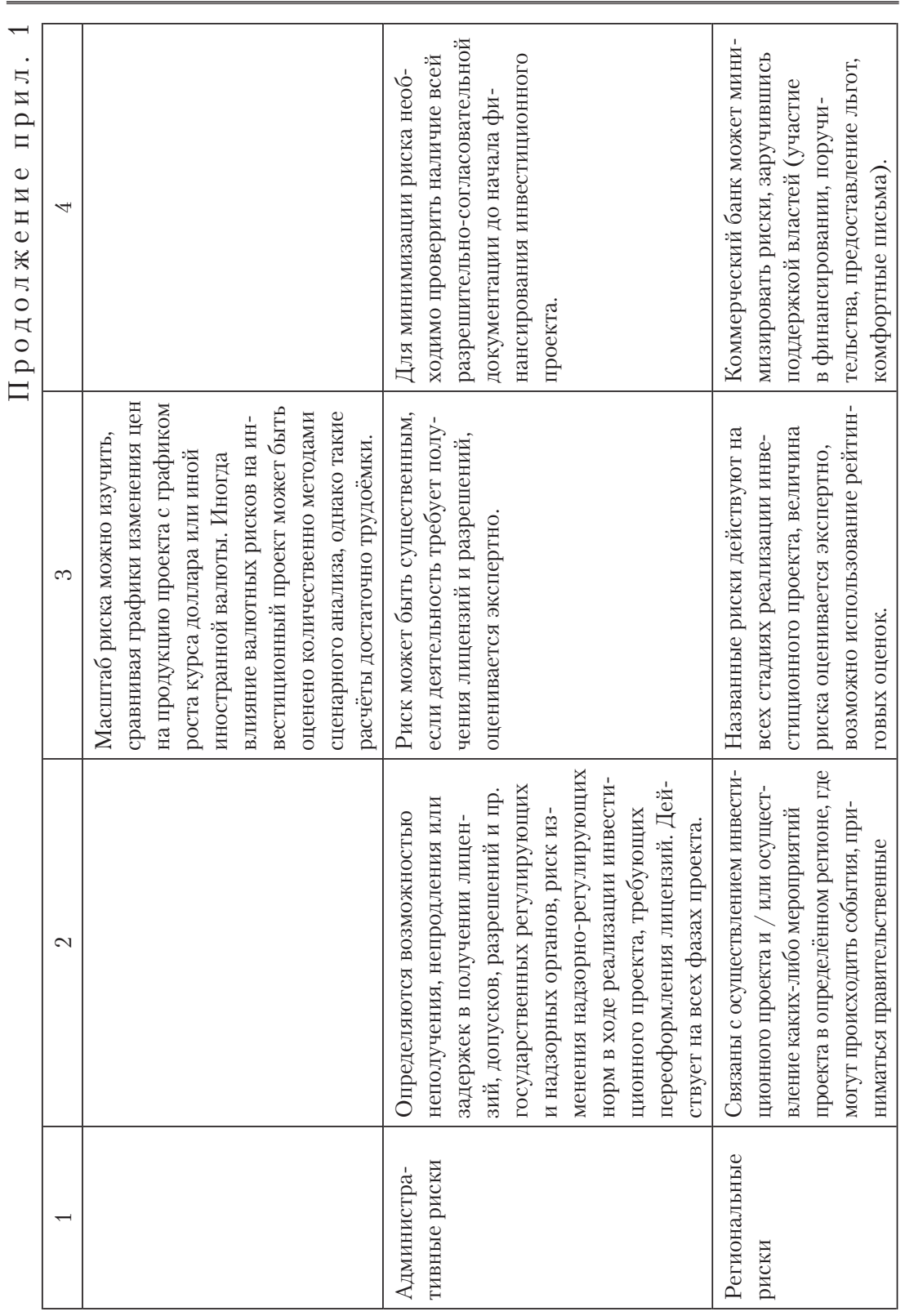




\section{П.П. Князев, М.Н. Клименко, Д.В. Моторнюк}

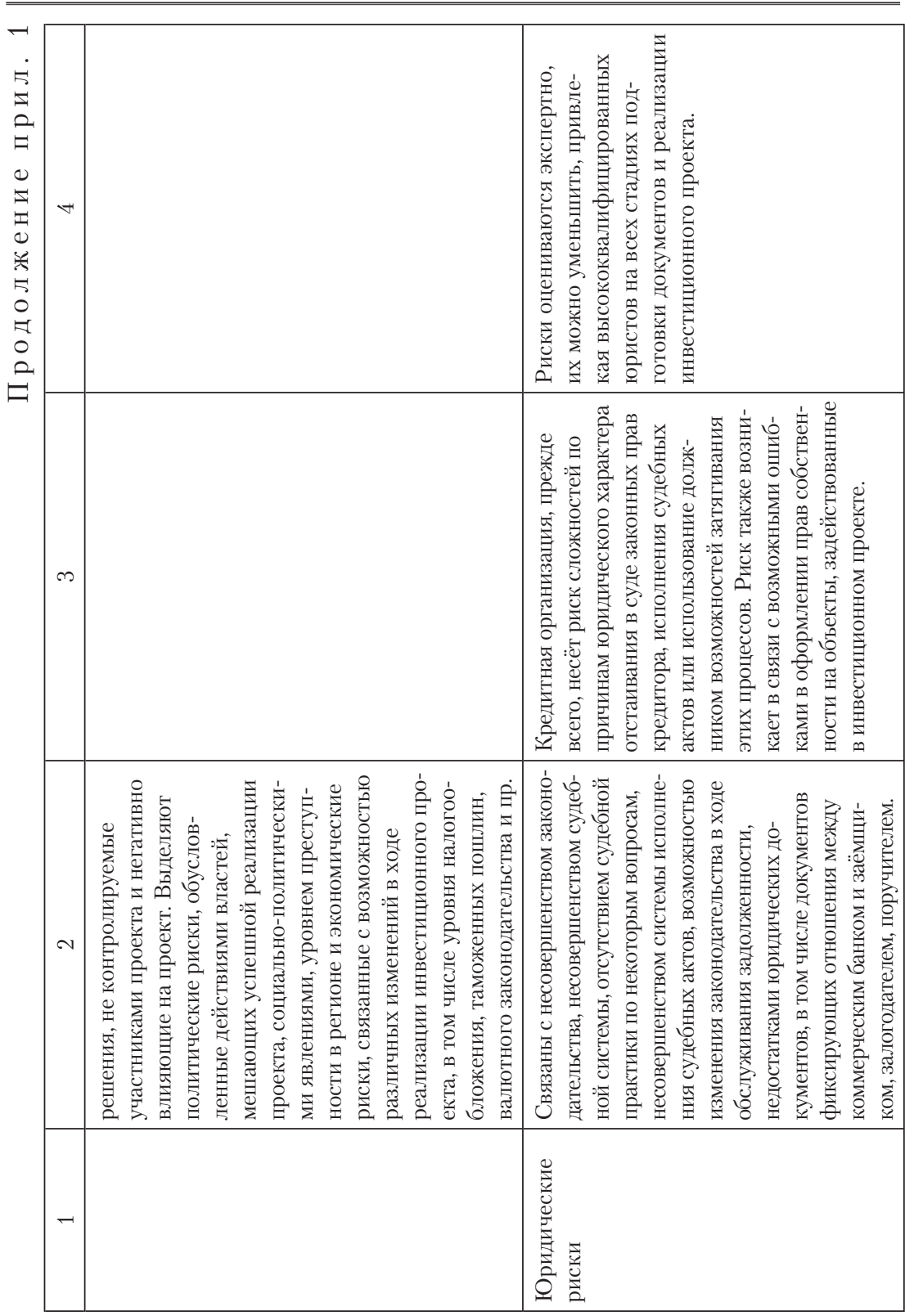




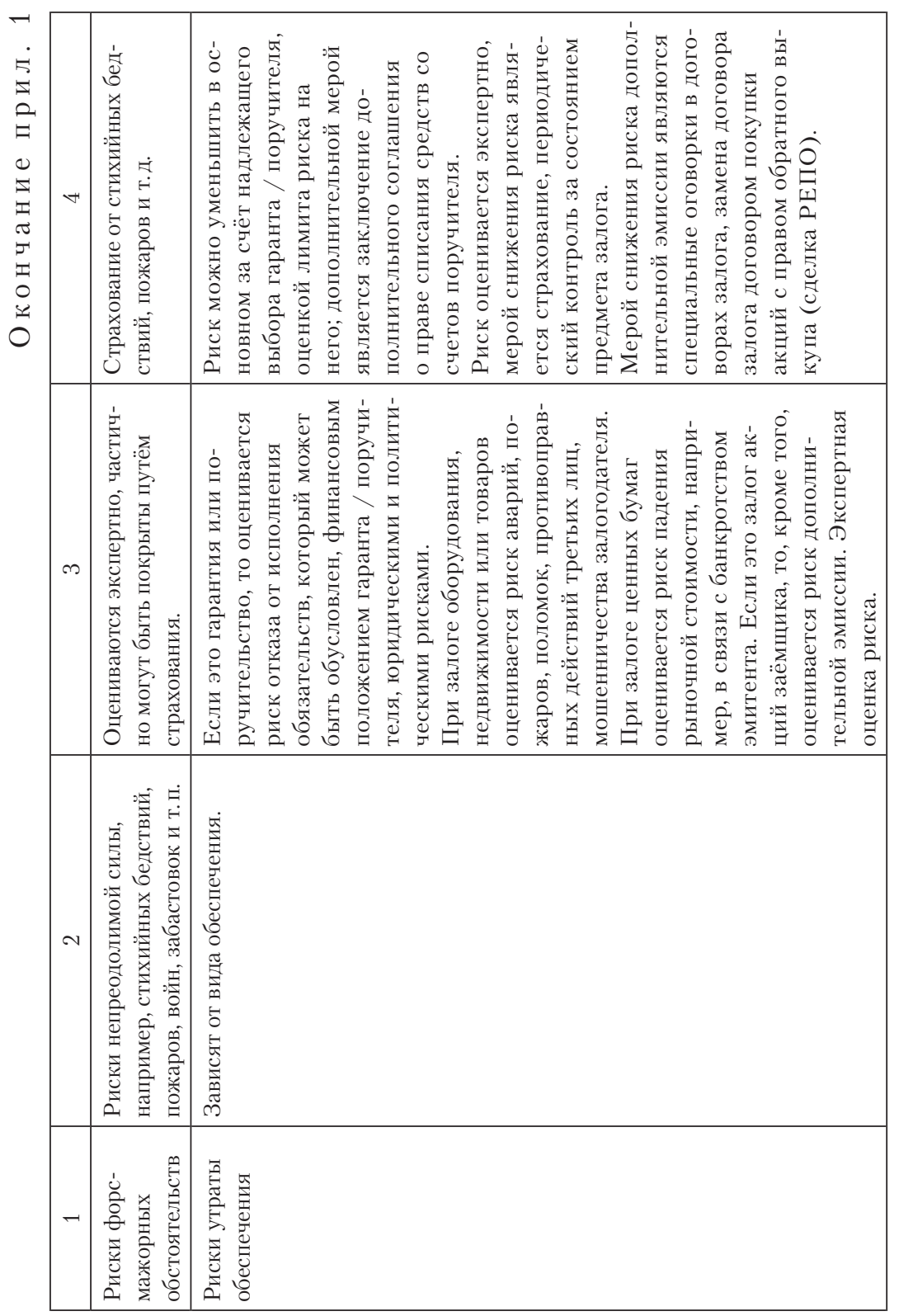




\section{П.П. Князев, М.Н. Клименко, Д.В. Моторнюк}

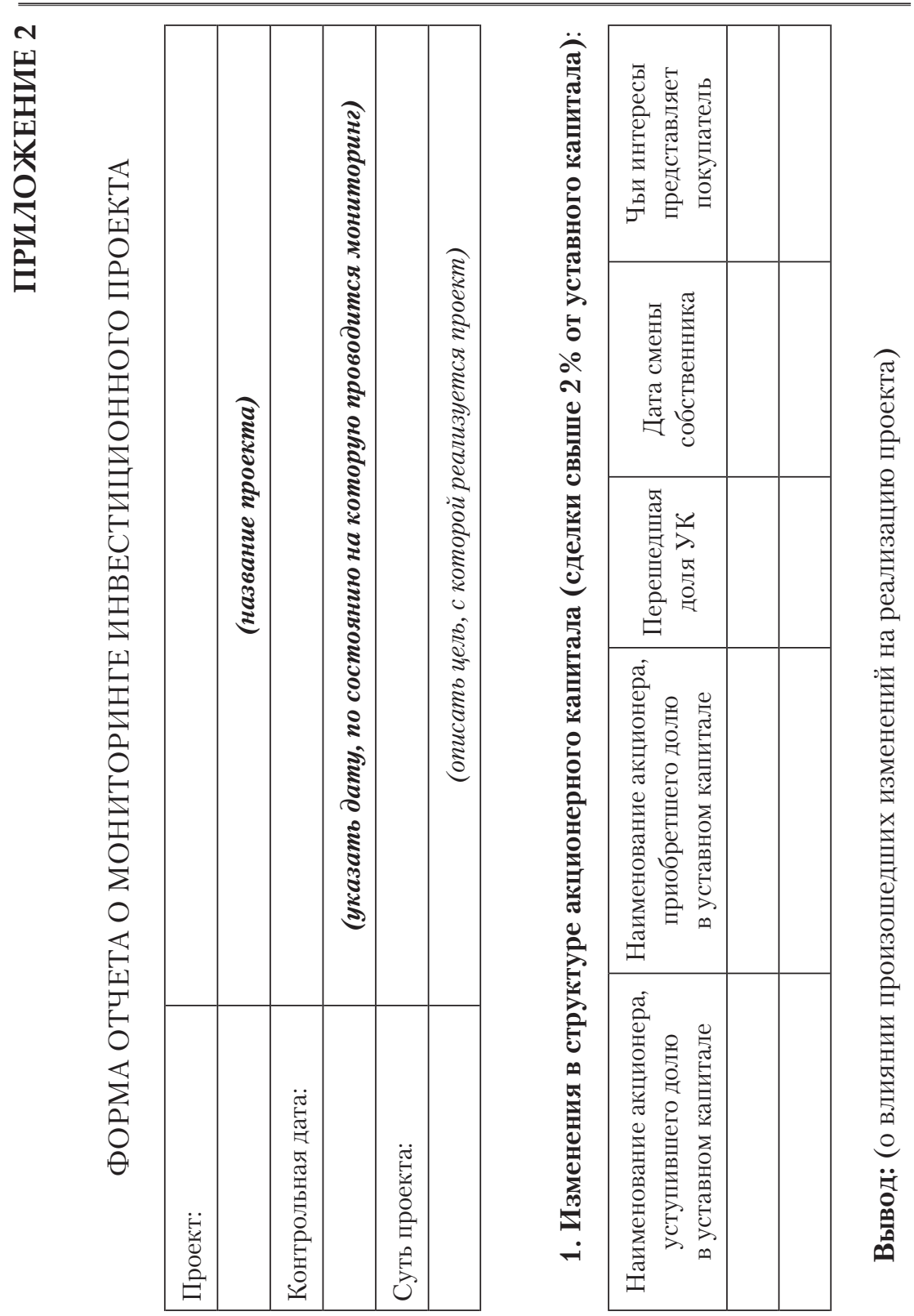



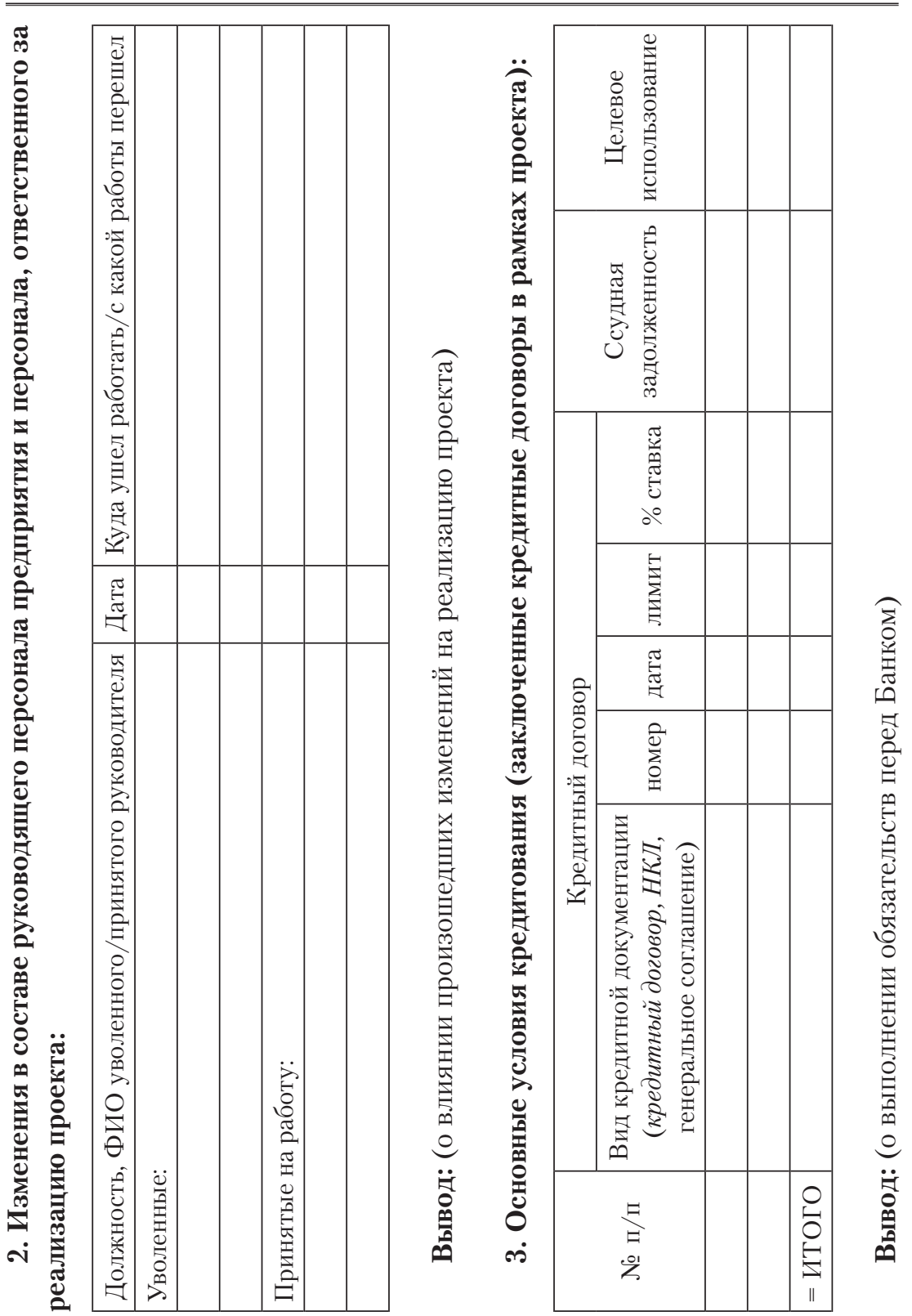


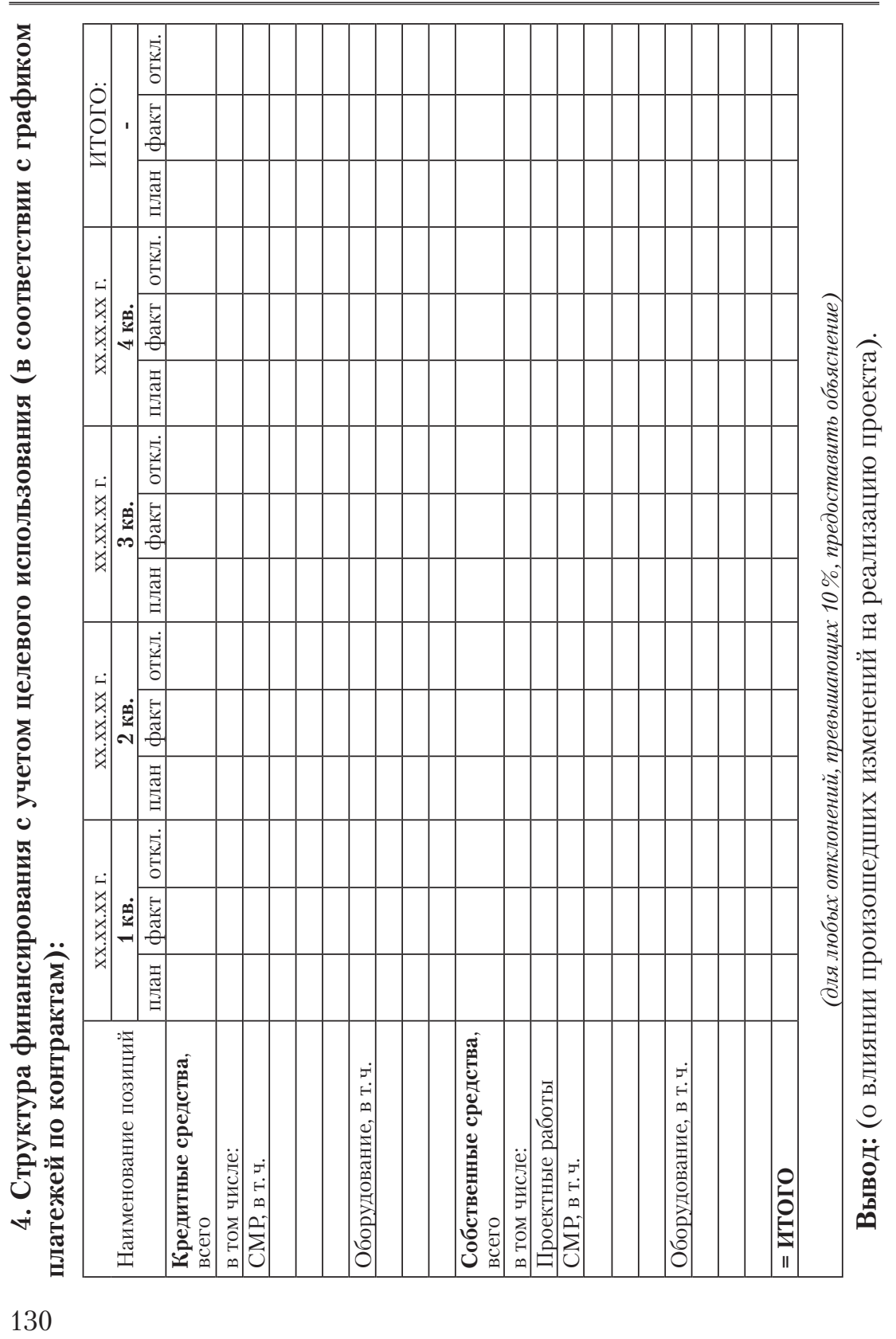




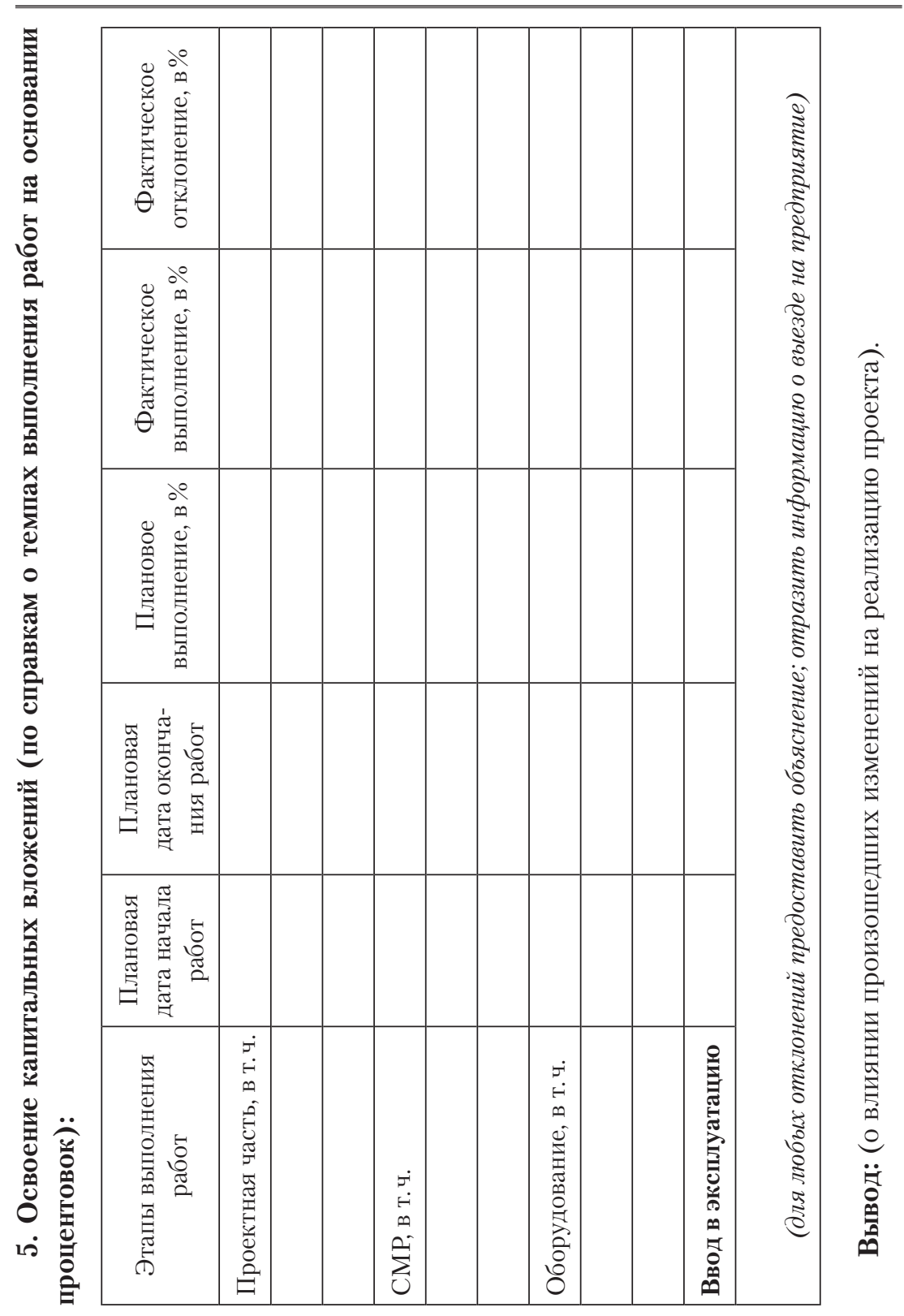




\section{П.П. Князев, М.Н. Клименко, Д.В. Моторнюк}

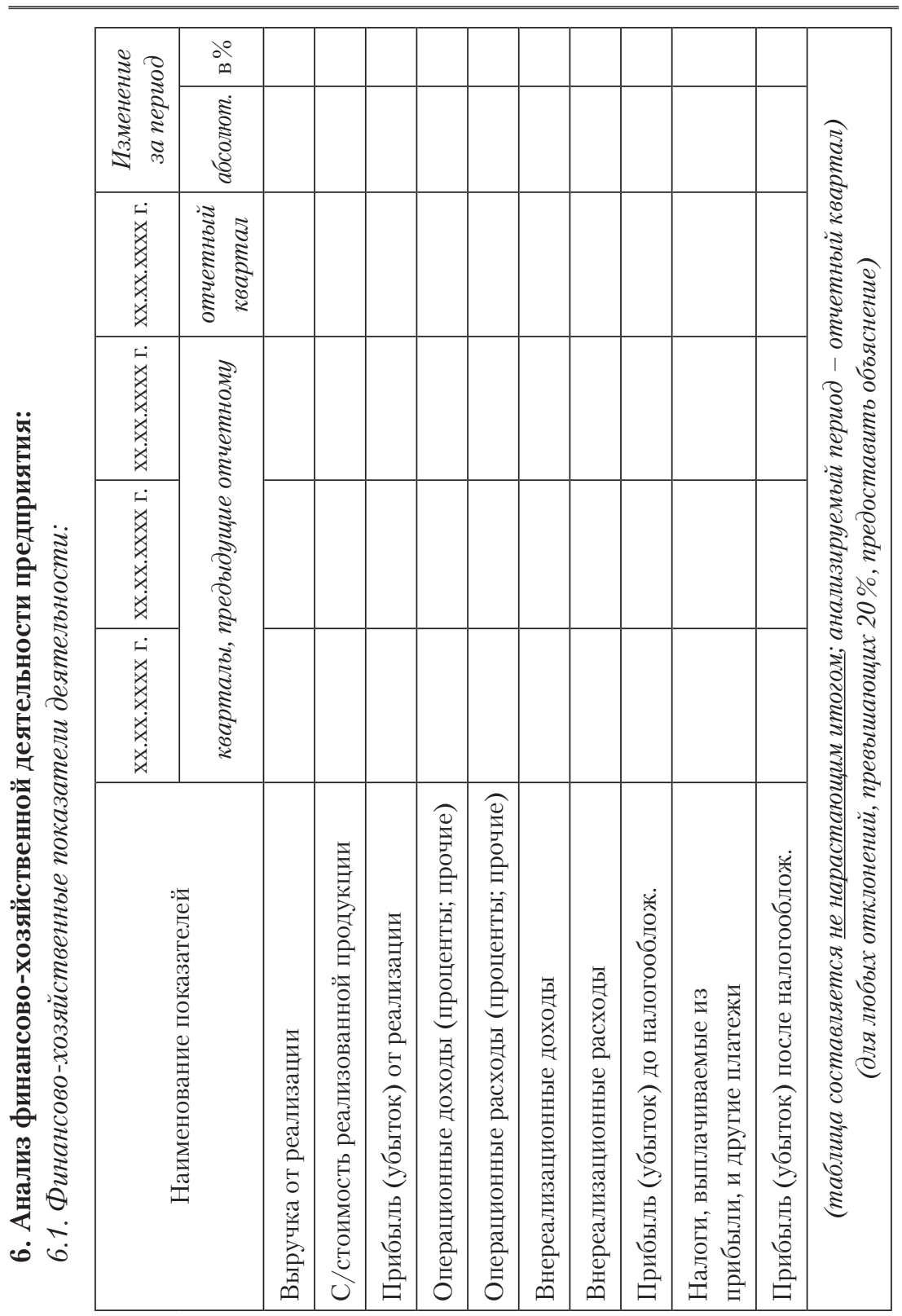


Прихожения

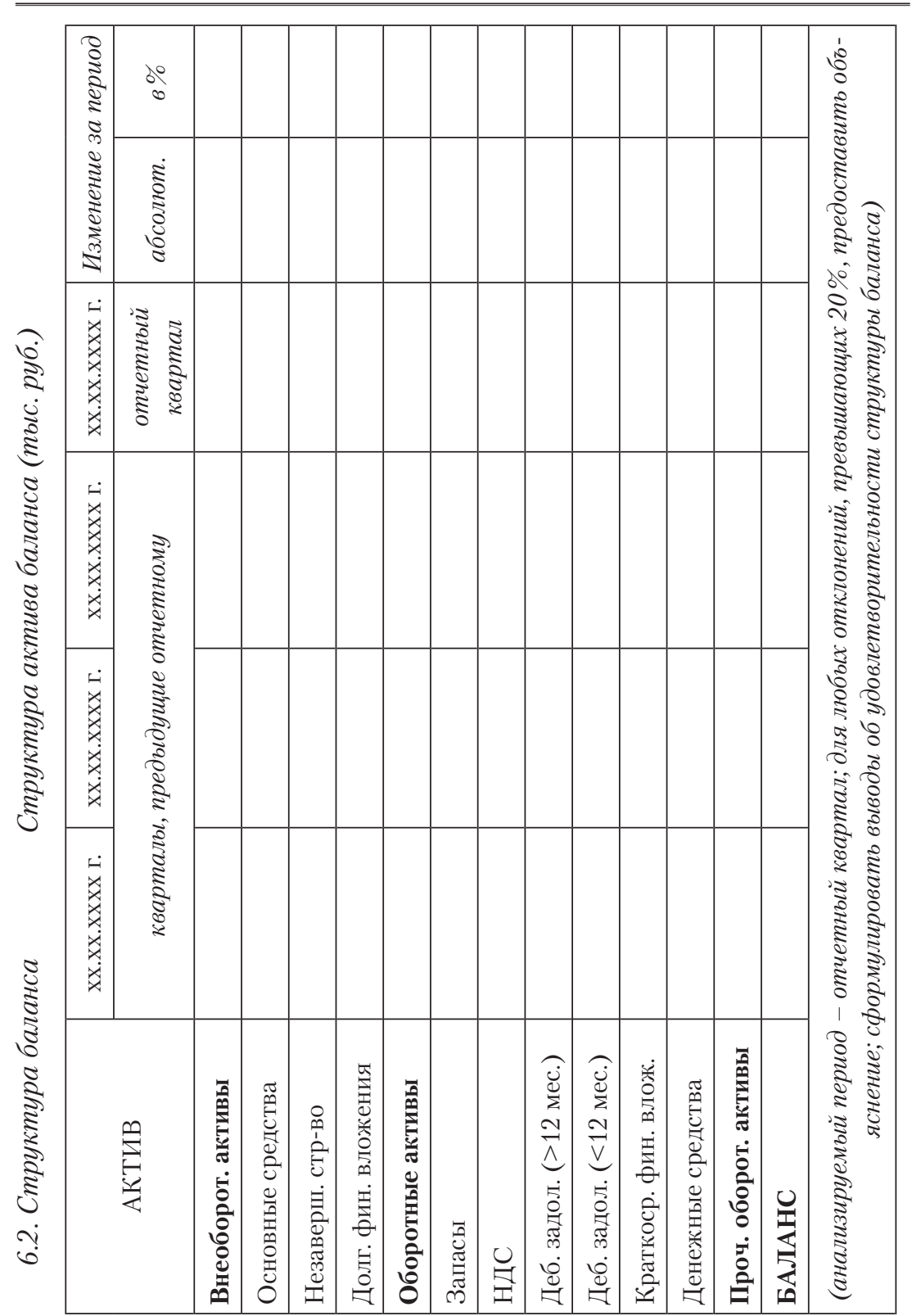


П.П. Князев, М.Н. Клименко, Д.В. Моторнюк

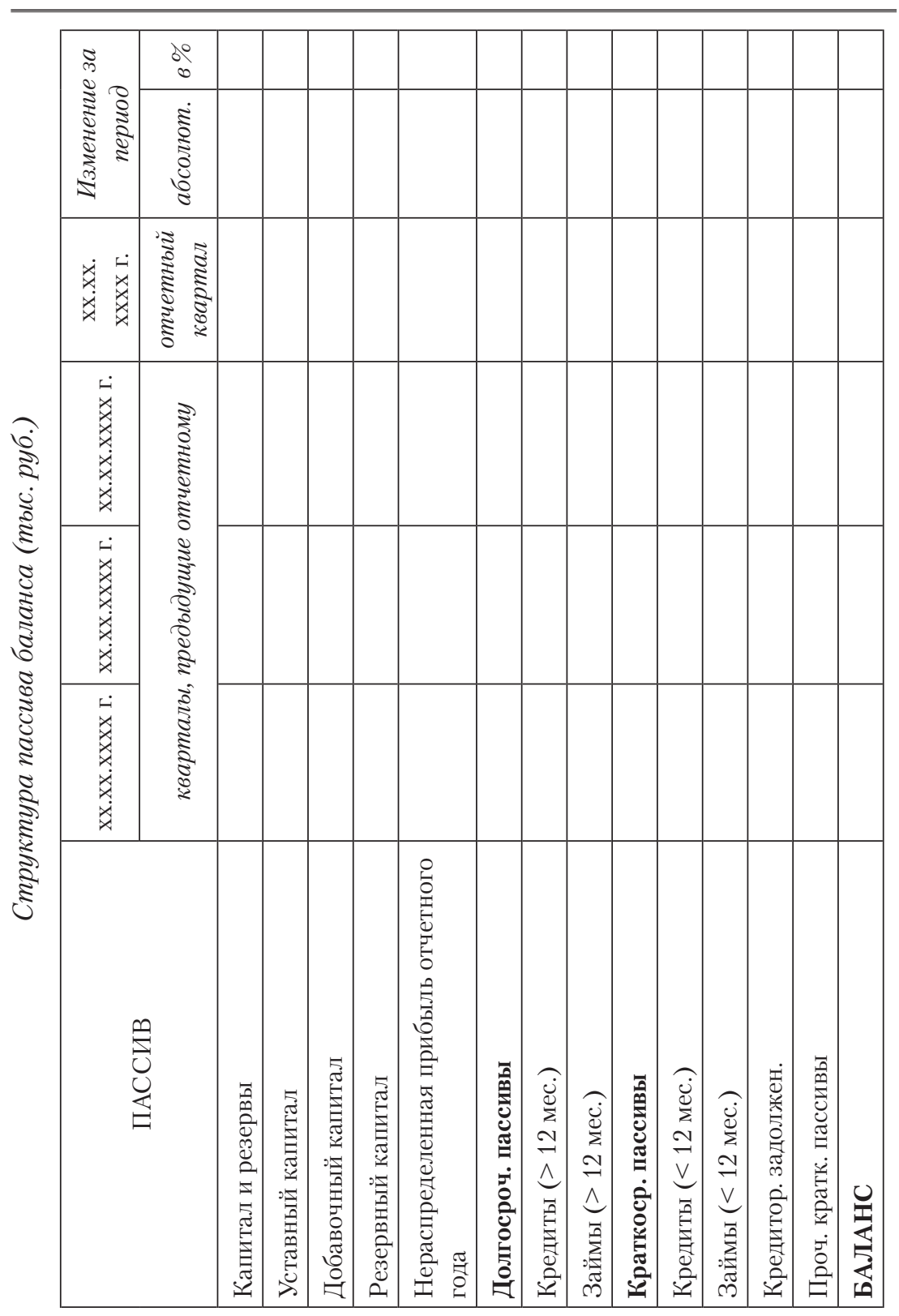



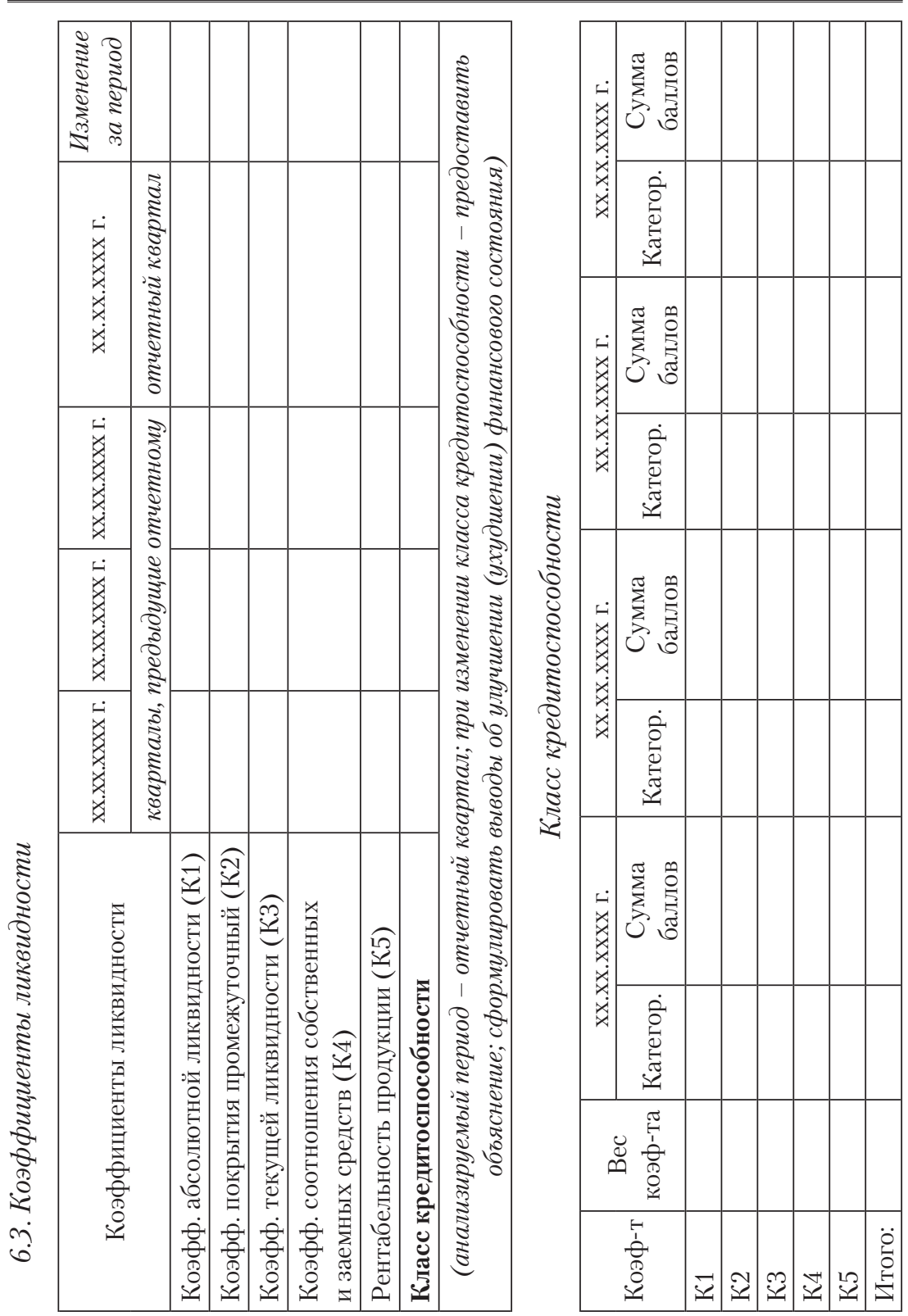


\section{П.П. Князев, М.Н. Клименко, Д.В. Моторнюк}

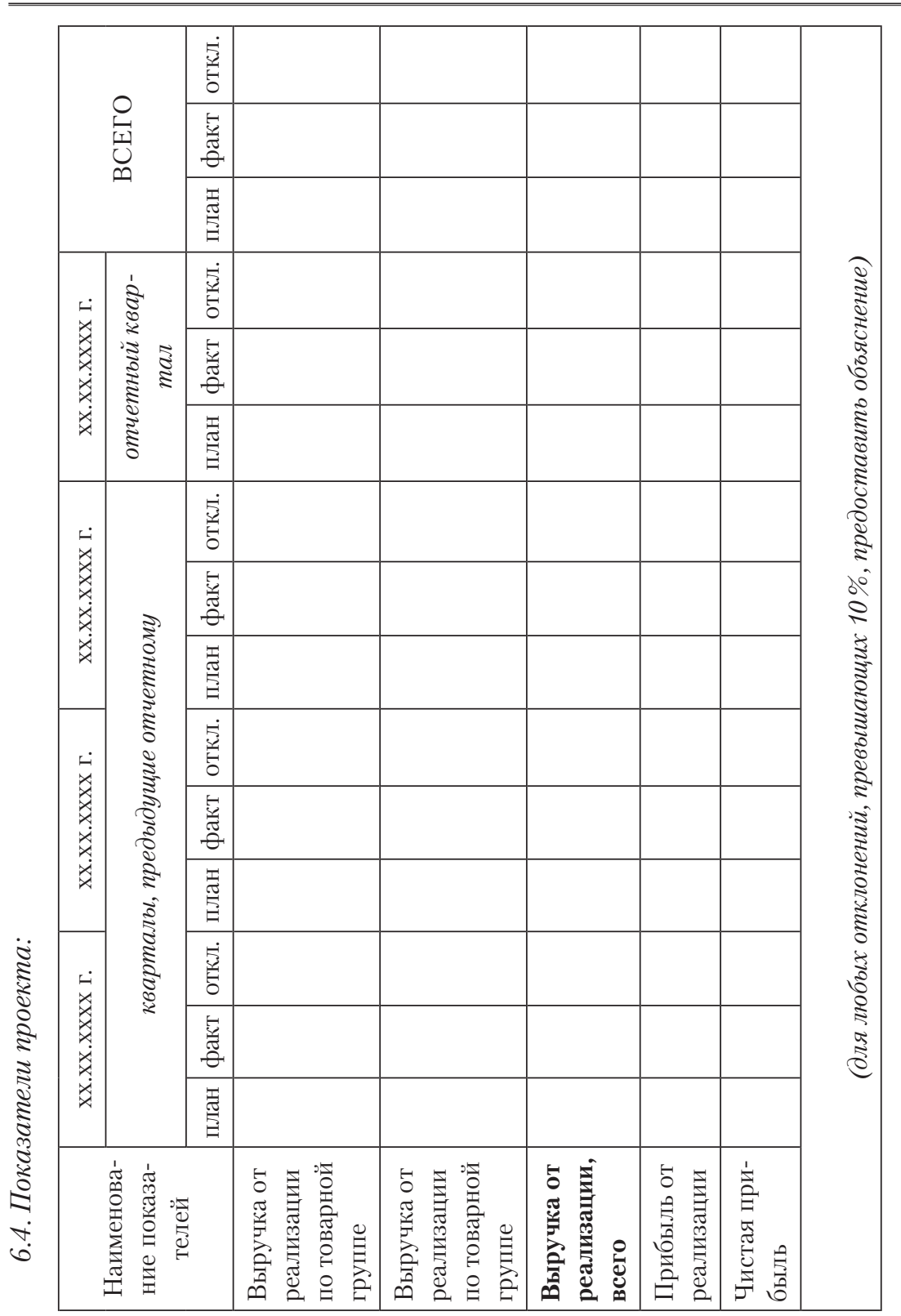



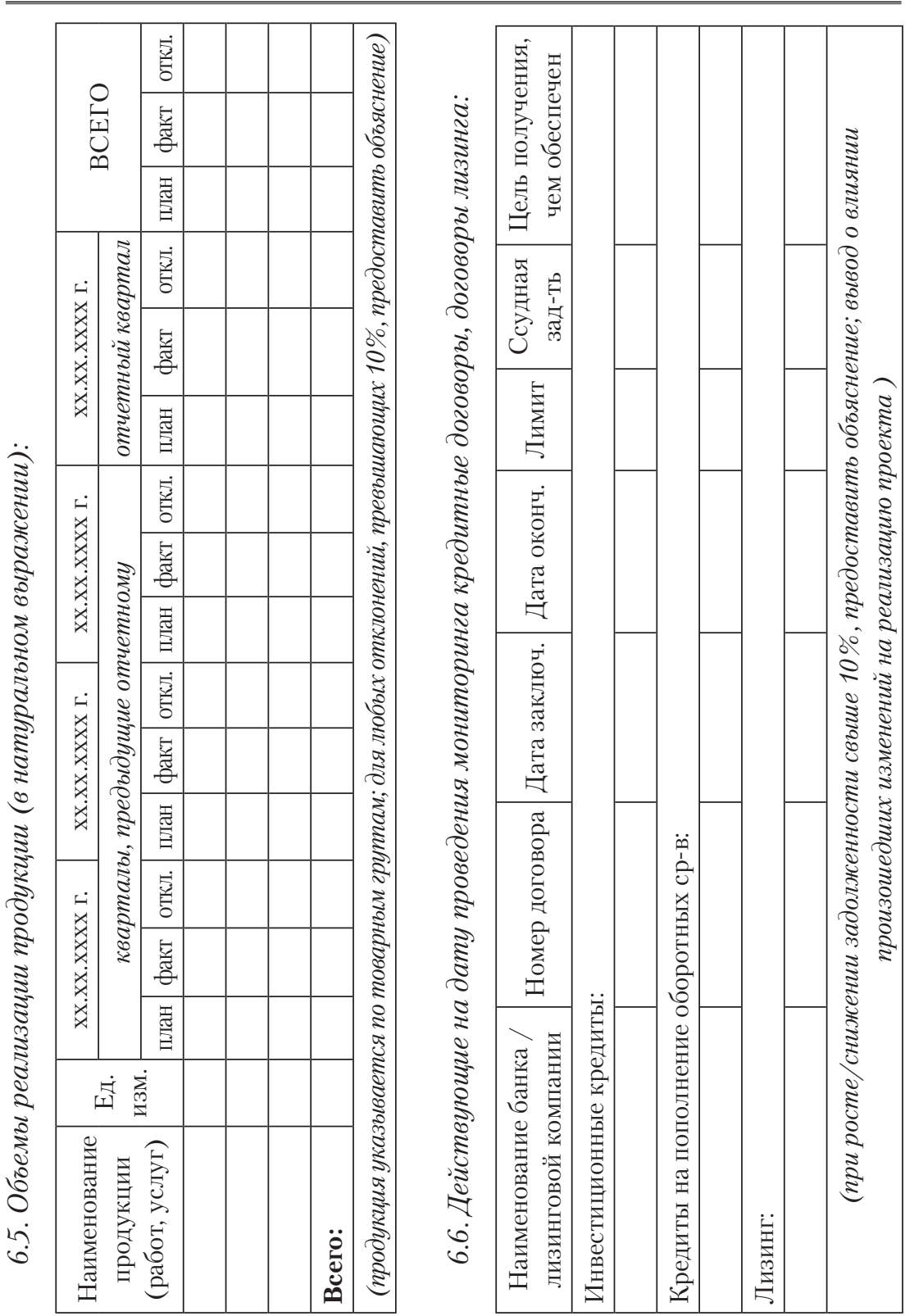


\section{П.П. Князев, М.Н. Клименко, Д.В. Моторнюк}
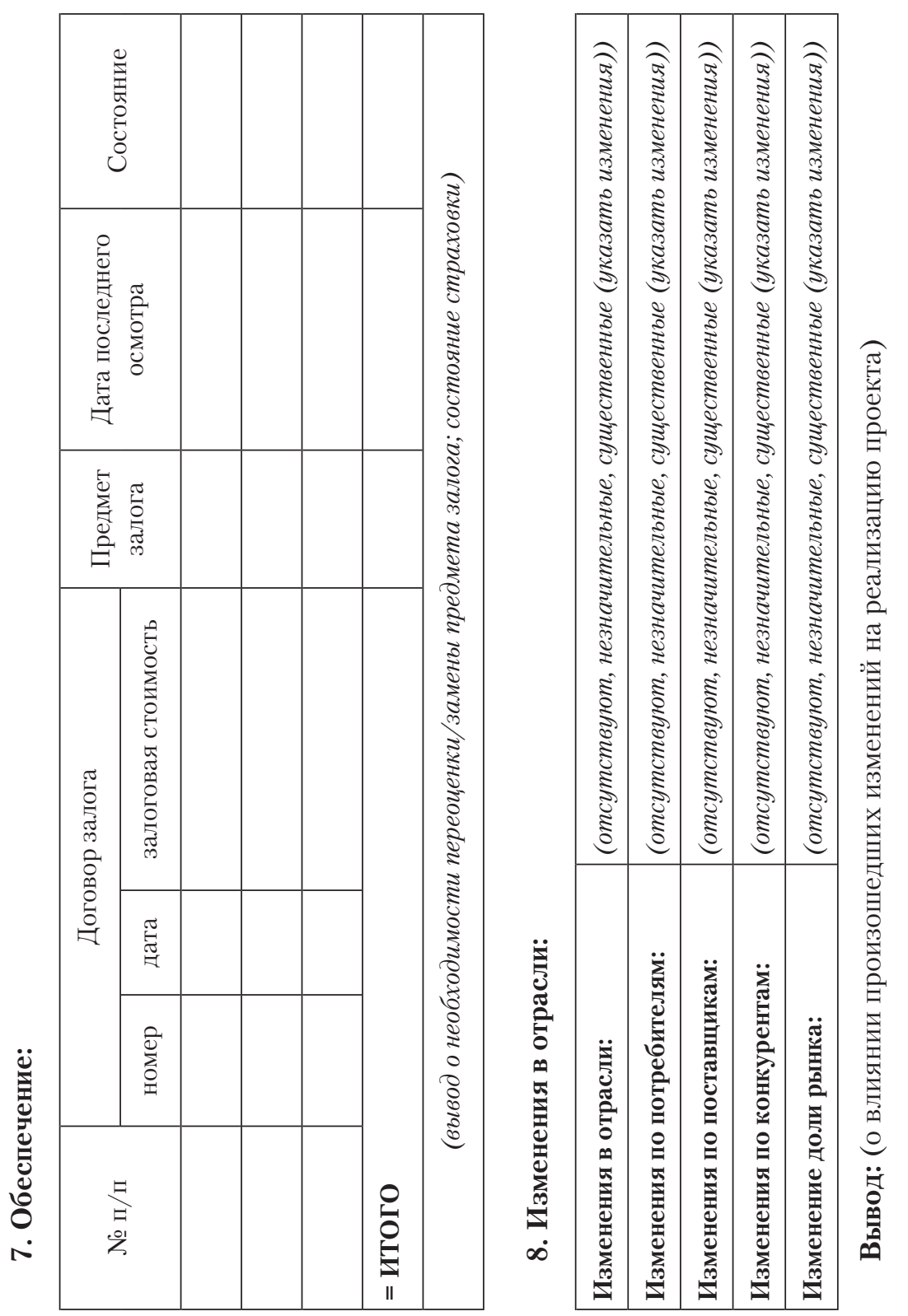


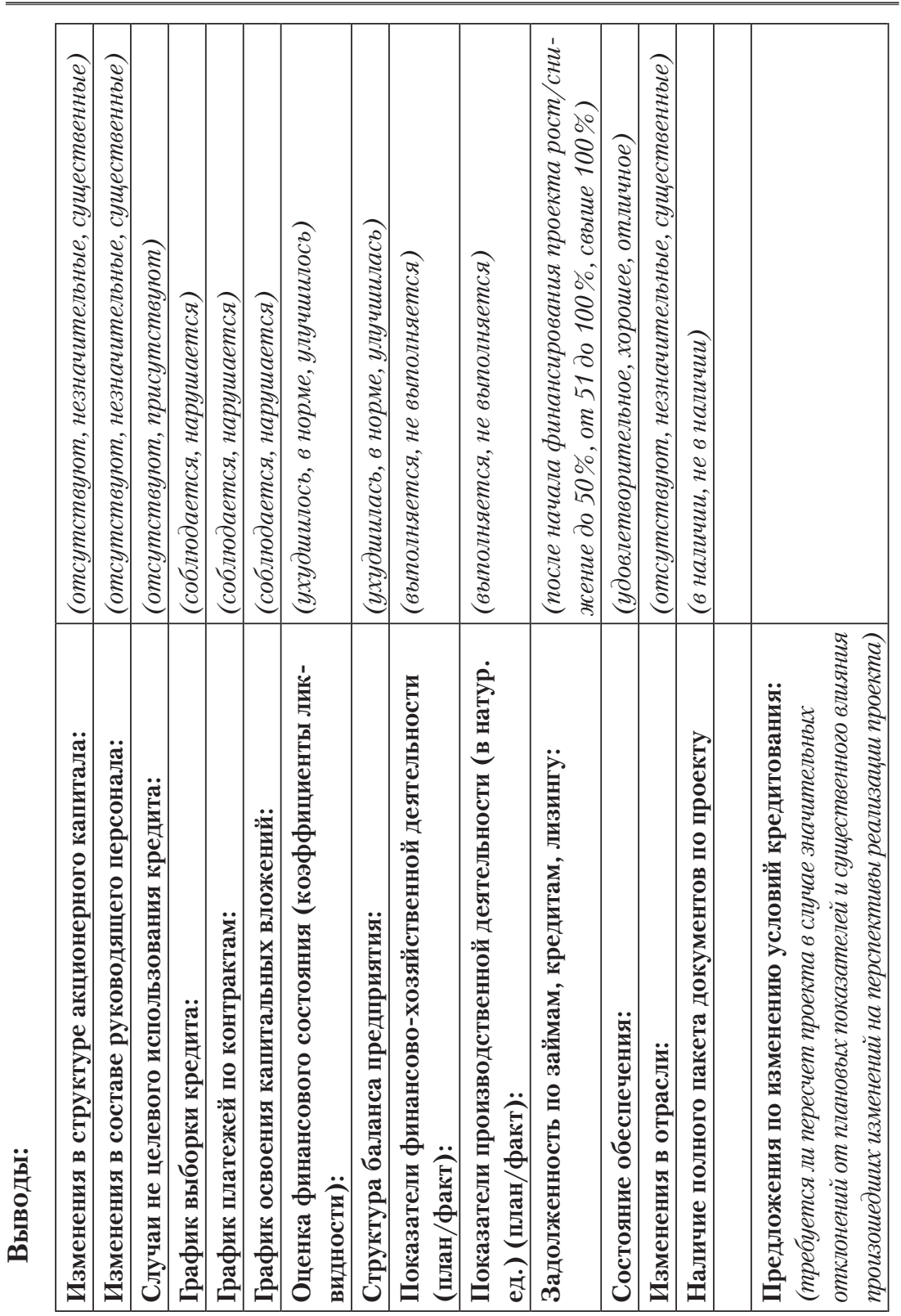


П.П. Князев, М.Н. Клименко, Д.В. Моторнюк

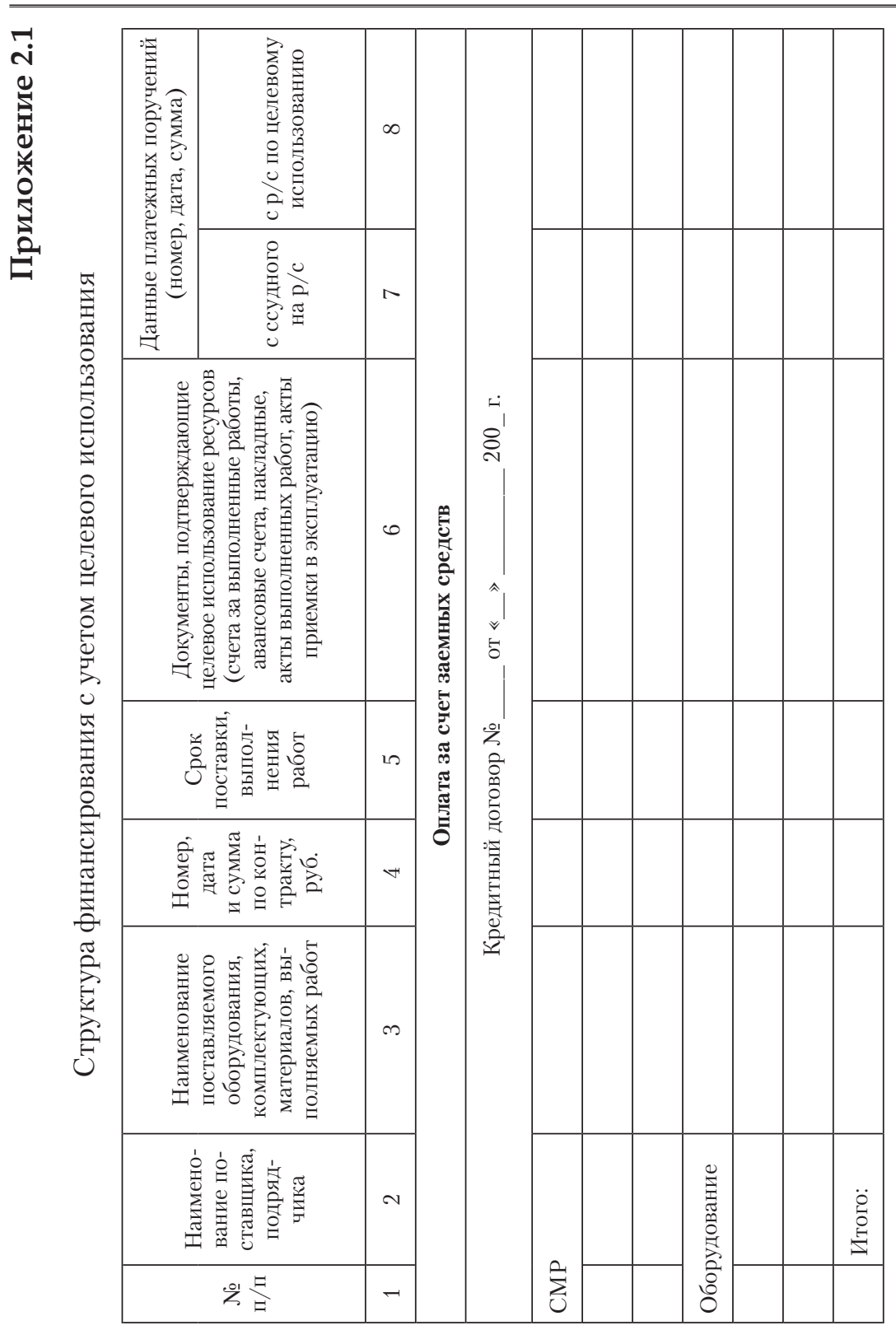




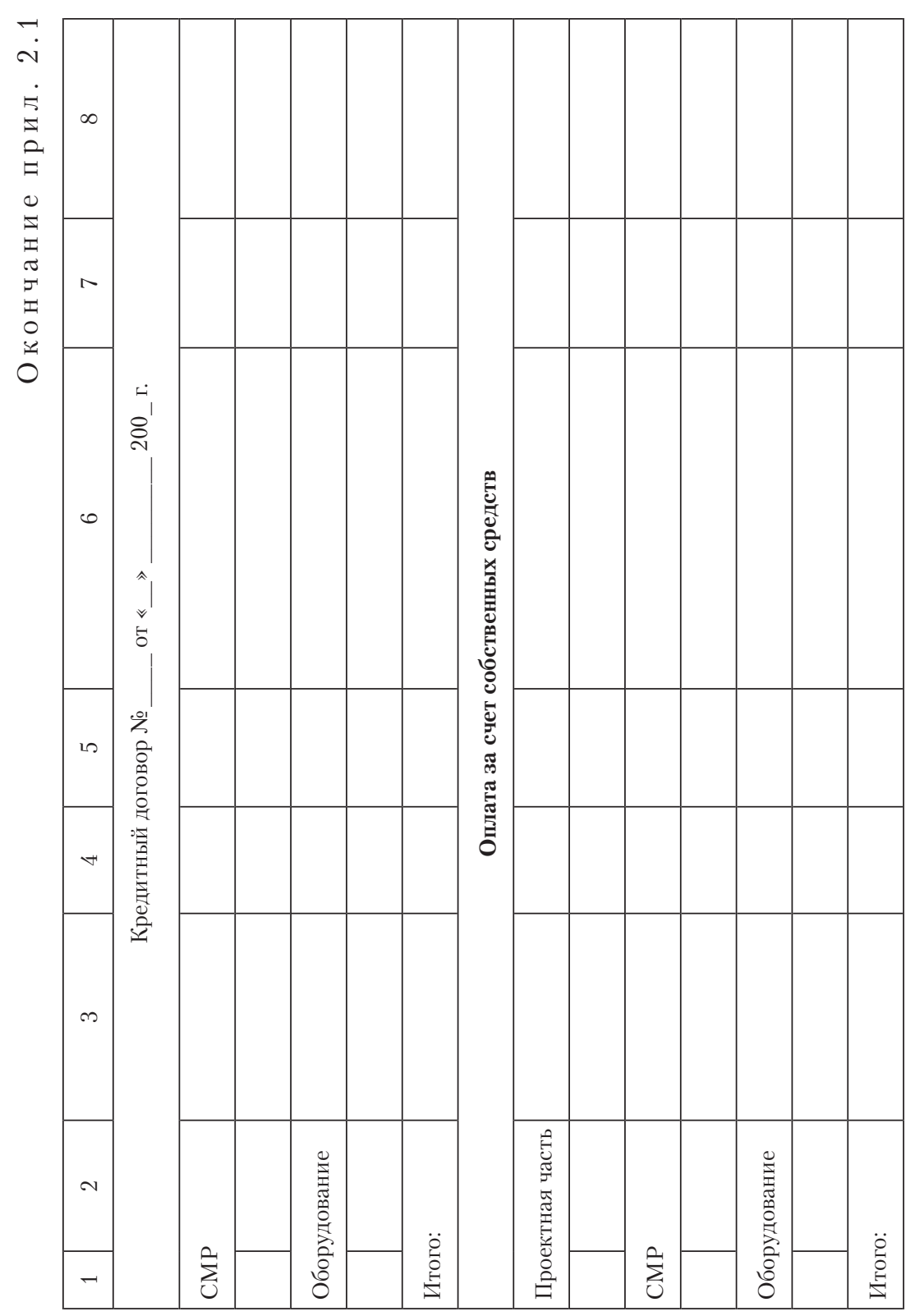


П.П. Князев, М.Н. Клименко, Д.В. Моторнюк

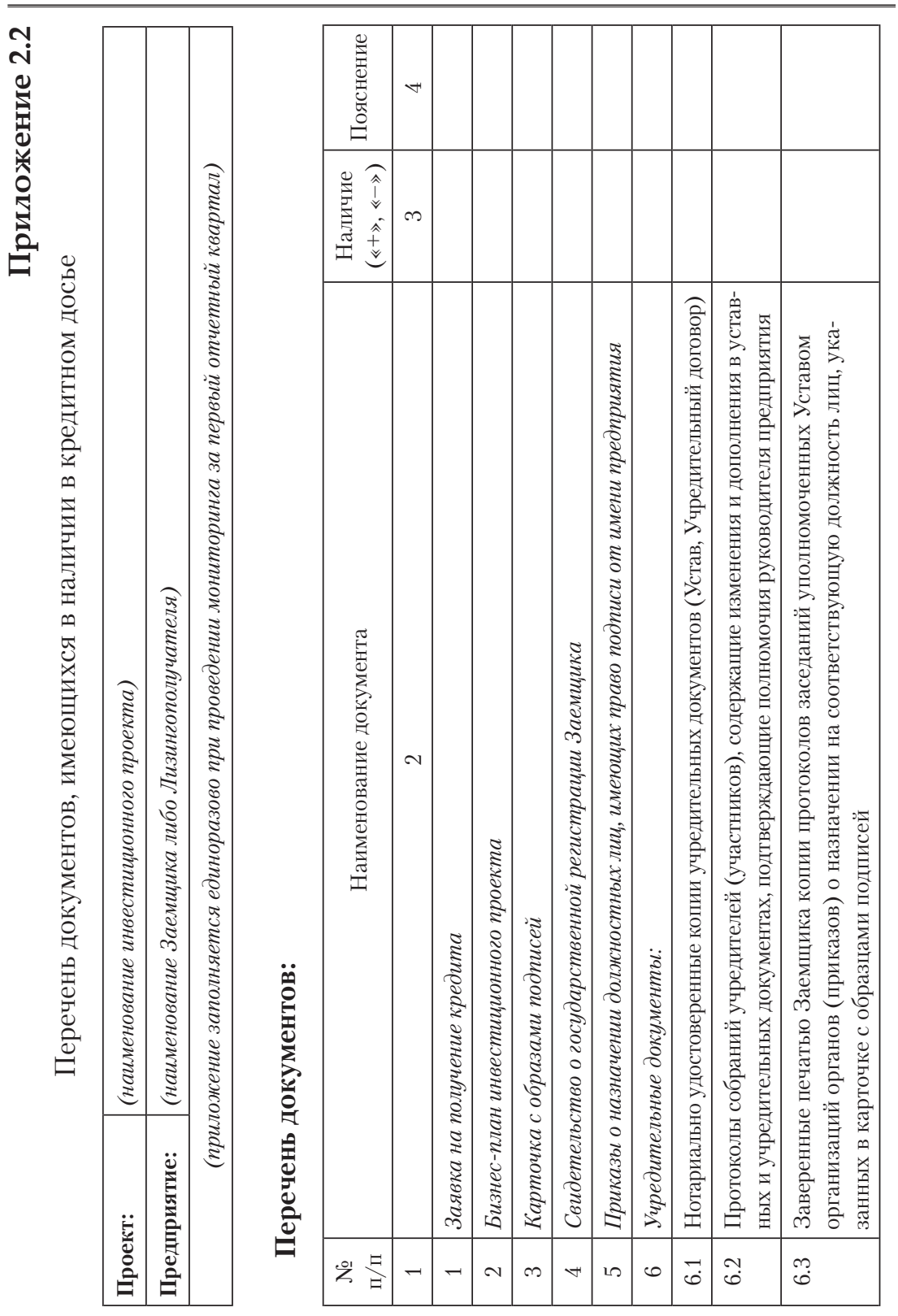




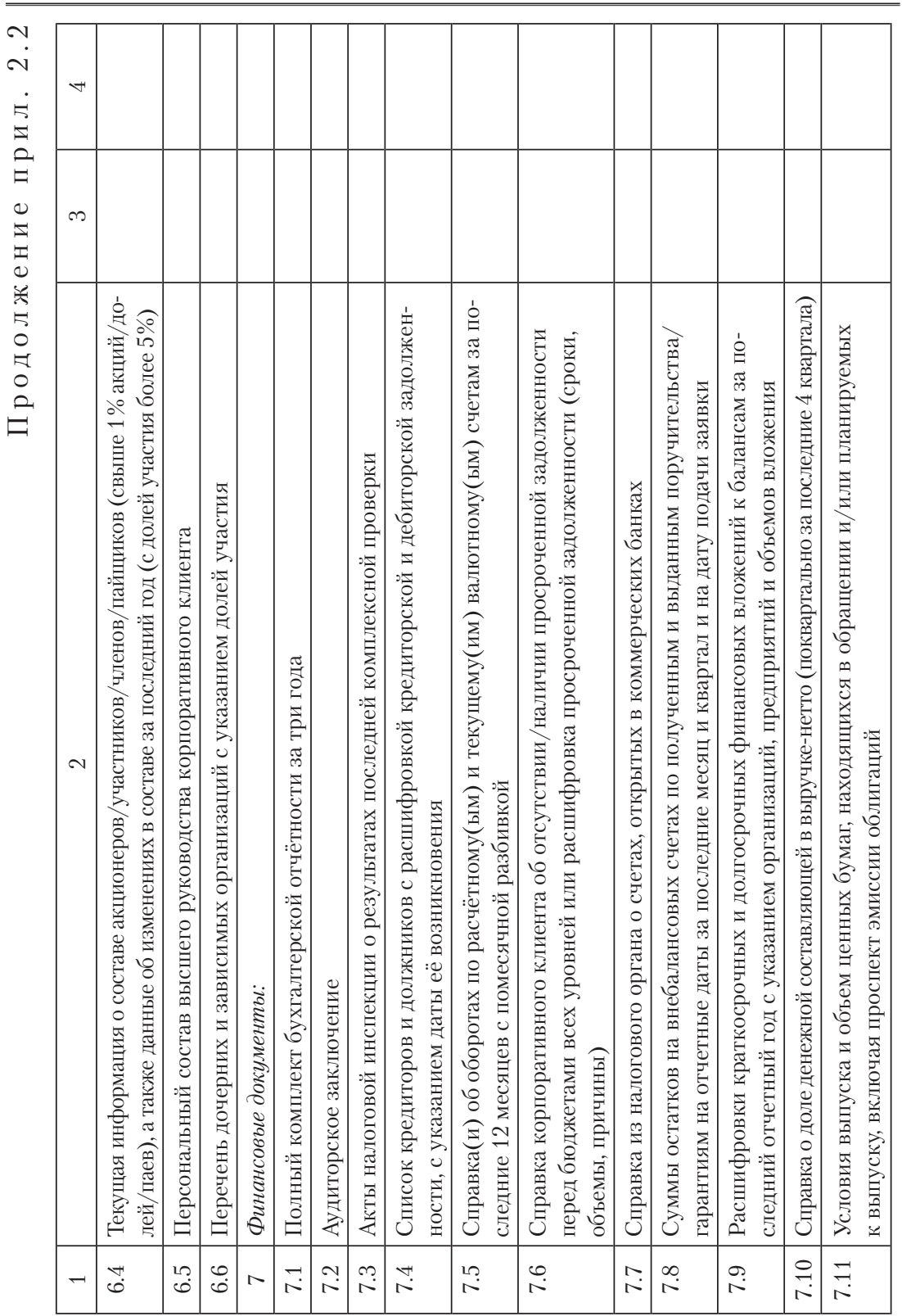




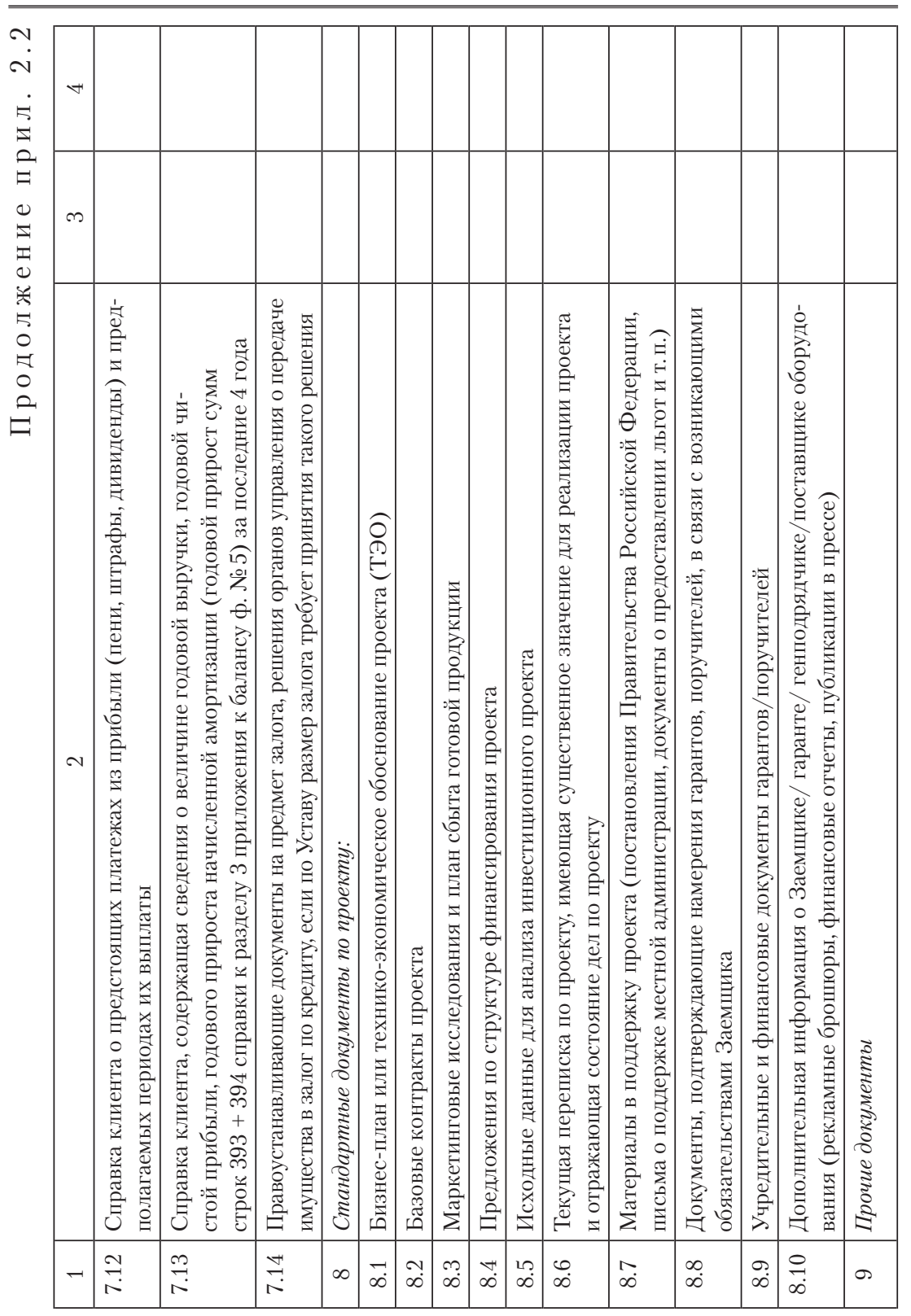




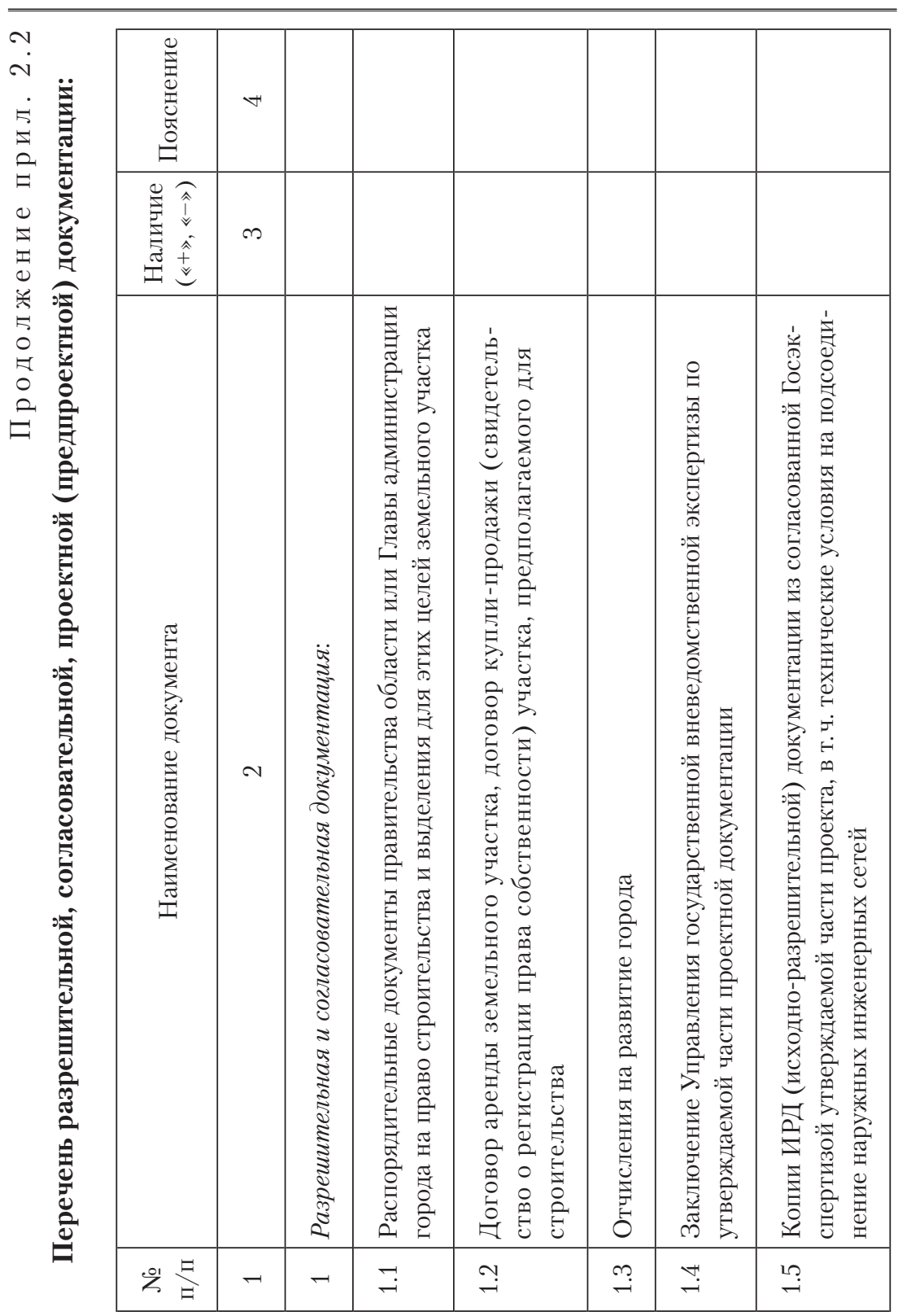




\section{П.П. Князев, М.Н. Клименко, Д.В. Моторнюк}

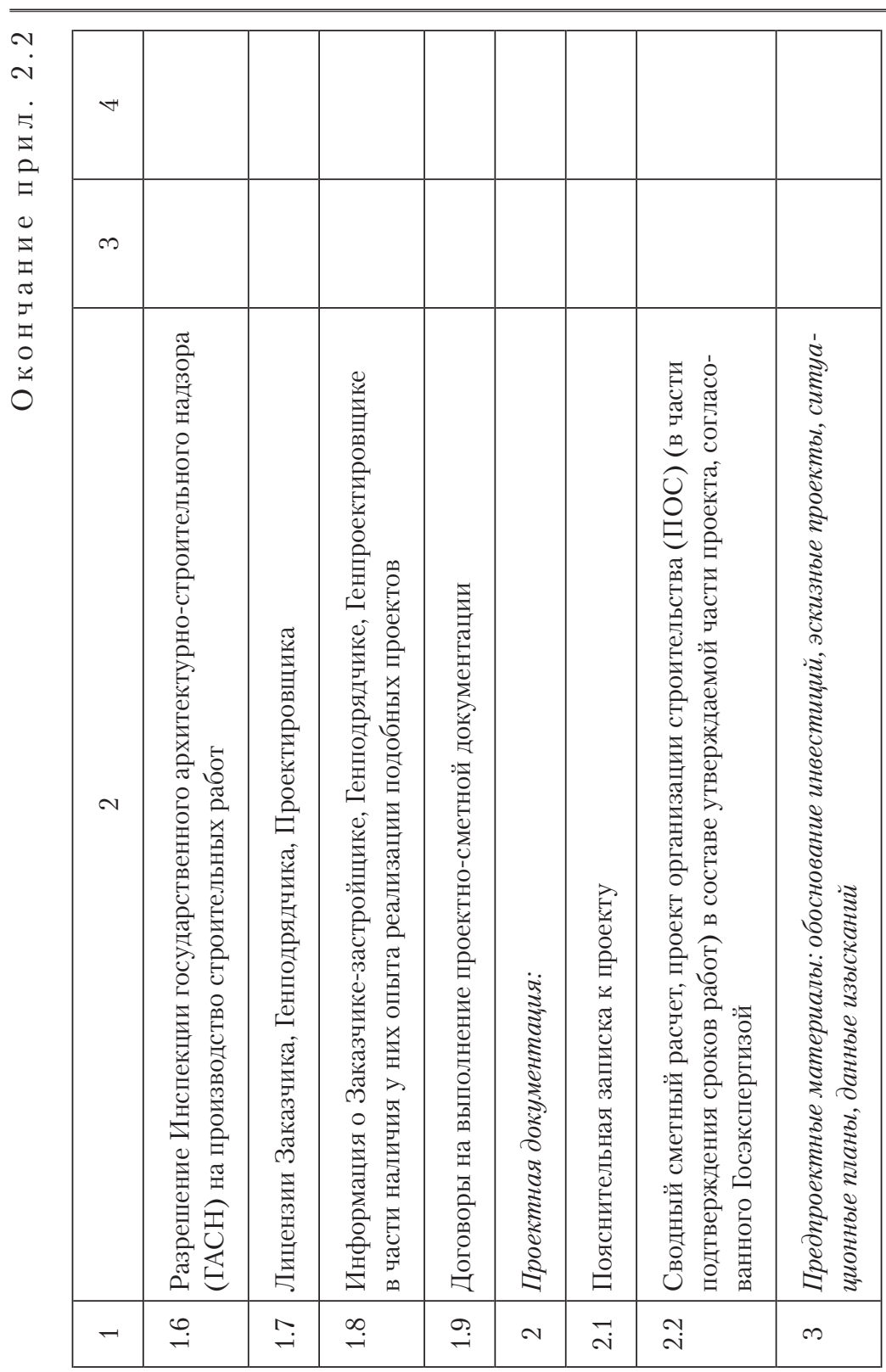




\section{ОГЛАВЛЕНИЕ}

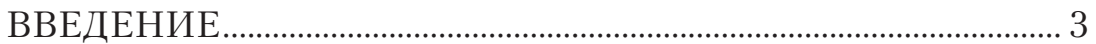

ГЛава 1. ТЕОРЕТИЧЕСКИЕ ОСНОВЫ

И ЭКОНОМИЧЕСКАЯ СУЩНОСТЬ ИНВЕСТИЦИОННОГО КРЕДИТОВАНИЯ ................ 6

1. Кредит и инвестиции как категориальные элементы экономической системы ...................................................... 6

2. Комплексная параметральная классификация инвестиций и кредита.

3. Кредитование инвестиционных проектов в воспроизводственной структуре

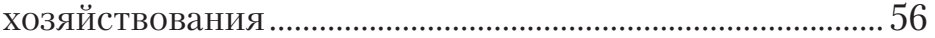

ГЛава 2. ОПРЕДЕЛЯЮЩИЕ НАПРАВЛЕНИЯ СОВЕРШЕНСТВОВАНИЯ МЕХАНИЗМА РЕАЛИЗАЦИИ ИНВЕСТИЦИОННОГО КРЕДИТОВАНИЯ

1. Алгоритм инвестиционно-кредитного администрирования в деятельности коммерческого банка. 74

2. Методика инвестиционно-кредитной экспертизы с применением стандарт-факторного анализа и модели адаптивных показателей 88

РЕКОМЕНДУЕМАЯ ЛИТЕРАТУРА .................................................112 ПРИЛОЖЕНИЯ 
Князев Павел Петрович Клименко Михаил Николаевич Моторнюк Дарья Викторовна

\title{
БАНКОВСКИЕ ПРОДУКТЫ И УСЛУГИ: ИНВЕСТИЦИОННОЕ КРЕДИТОВАНИЕ
}

\author{
Учебное пособие
}

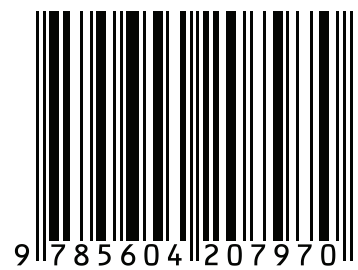

Технический редактор Кулакова Г.А.

Подписано в печать 11.06.2019

Бумага офсетная.

Гарнитура PetersburgC

Формат $60 \times 841 / 16$

Печать трафаретная. Печ. л. 9,25.

Тираж 500 экз. Заказ № 008-19.

Отпечатано в типографии Евроазиатской научно-промышленной палаты, 410035, г. Саратов, ул. Мамонтовой, д. 5 